\title{
In situ and in vitro analysis of germ and stem cell marker-positive cells in the postnatal ovary of the common marmoset monkey (Callithrix jacchus)
}

\section{Dissertation}

\author{
for the award of the degree \\ "Doctor rerum naturalium" (Dr.rer.nat.) \\ of the Georg-August-Universität Göttingen \\ within the doctoral program Biology \\ of the Georg-August University School of Science (GAUSS) \\ submitted by Bentolhoda Fereydouni
}

from Shiraz /Iran

Göttingen, 2014 


\section{$\underline{\text { Thesis Committee members }}$}

\section{Prof. Dr. Sigrid Hoyer-Fender}

Department of Developmental Biology, GZMB, Johann-Friedrich-Blumenbach, Institute for Zoology and Anthropology, Göttingen

Prof. Dr. Lutz Walter

Primate Genetics Laboratory, German Primate Center, Leibniz Institute for Primate Research, Göttingen

Prof. Dr. Rüdiger Behr

Stem Cell Biology Unit, German Primate Center, Leibniz Institute for Primate Research, Göttingen

\section{Members of the Examination Board}

\section{Reviewer1:}

Prof. Dr. Michael Kessel, Department of Developmental Biology, Max Planck Institute for Biophysical Chemistry, Göttingen

\section{Reviewer2:}

PD Dr. Halyna Shcherbata, Gene Expression and Signaling Group, Max Planck Institute for Biophysical Chemistry, Göttingen

\section{Reviewer3:}

Dr. Antje Engelhardt, Jr. Research Group Primate Sexual Selection, German Primate Center, Leibniz Institute for Primate Research, Göttingen

\section{Reviewer4:}

Dr. Nikola-Michael Prpic-Schäper, Department of Developmental Biology, GZMB, JohannFriedrich-Blumenbach-Institute of Zoology and Anthropology, Georg August University, Göttingen

\section{Date of the oral examination:}




\section{Affidavit}

Here I declare that my doctoral thesis entitled" In situ and in vitro analysis of germ and stem cell marker-positive cells in the postnatal ovary of the common marmoset monkey (Callithrix jacchus)" has been written independently with no other sources and aids than quoted.

Bentolhoda Fereydouni

Göttingen, 2014 
To my father Shapour and my mother Mehri 


\section{Table of Contents}

Acknowledgment ................................................................................................................. vi

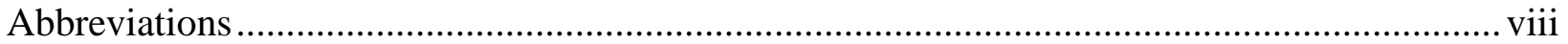

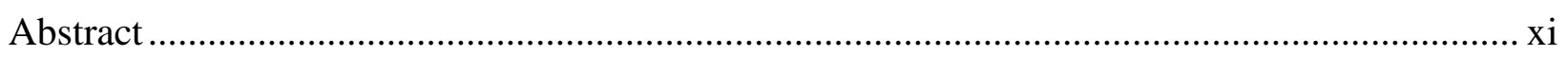

1 Introduction .....................................................................................................................

$1.1 \quad$ The female reproductive tract ............................................................................................. 1

1.2 Development of the premeiotic ovarian germ cell population......................................................... 1

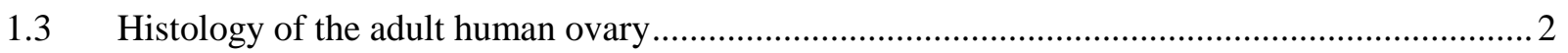

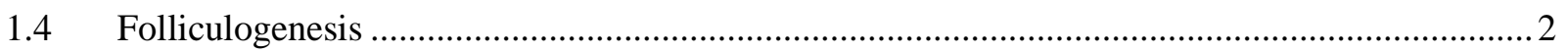

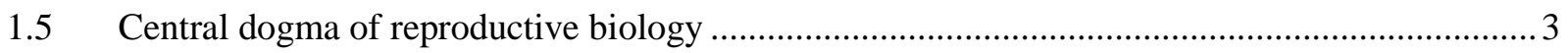

1.6 Renewal of germ cells after birth (Neo-oogenesis in postnatal mammalian ovary) ....................... 5

$1.7 \quad$ The origin of germline stem cells ........................................................................................

1.8 The common marmoset monkey (Callithrix jacchus) ……………………………………….....

1.9 Aims of the Study ............................................................................................................

2 Original Publications in peer-reviewed journals ........................................................................... 8

3 Summary of the results..............................................................................................................

3.1 Histology of the neonatal marmoset ovary ………………………………………………....... 77

3.2 Neonatal marmoset ovaries contain numerous premeiotic germ cells expressing pluripotency

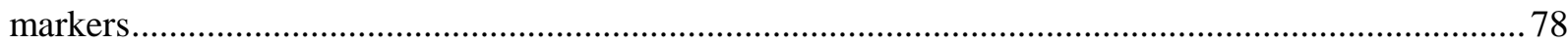

3.3 Presence of pluripotency and germ cell factor mRNAs in the marmoset neonatal ovary............ 80

3.4 Co-localization of the germ cell marker VASA with pluripotency markers.................................. 80

3.5 The proliferation marker Ki-67 is strongly expressed by oogonia.............................................. 80

3.6 Co-localization of Ki-67 with the pluripotency markers OCT4A and LIN28 ….......................... 81

3.7 Establishing two different long-term culture methods from the marmoset neonatal primary cell

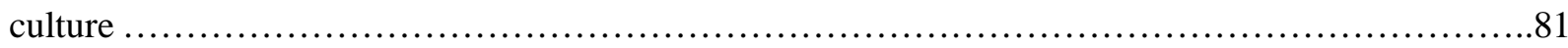

3.8 Transcriptome analysis of ovarian cell colonies (OCCs) reveals an immediate loss of the germ

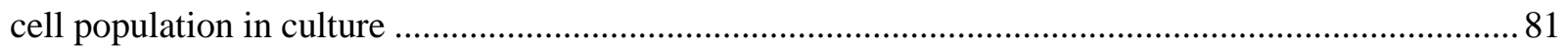

$3.9 \quad$ RT-qPCR analysis showed the expression of germ cell markers in OCCs.................................. 82

3.10 The OCCs under C1 generate oocyte-like cells (OLCs) ............................................................. 83

3.11 OLCs express the germ cell markers VASA, DAZL, and NOBOX on the mRNA level ............... 83

3.12 Expression of germ cell marker VASA on the protein level by OLCs ........................................ 84

3.13 The relative abundance of the markers is decreasing within one passage ..................................... 84 


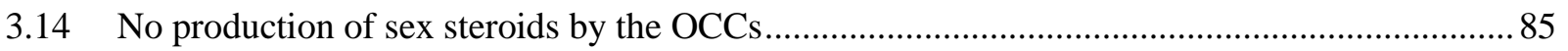

3.15 Neither teratoma nor ovarian tissue formation in a transplantation assay .................................. 85

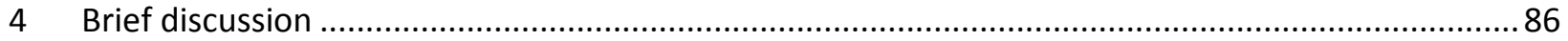

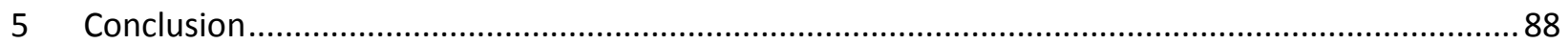

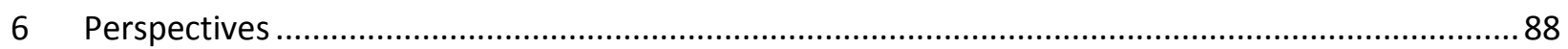

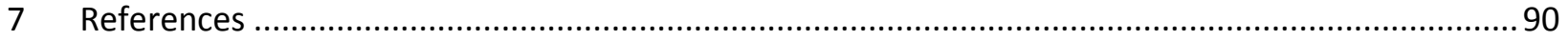

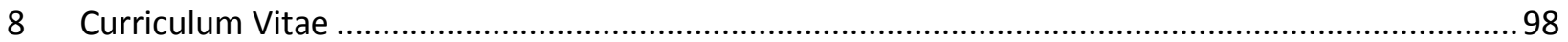




\section{Acknowledgements}

I would like to gratefully thank my supervisor Prof. Dr. rer. nat Rüdiger Behr for giving me the opportunity to do my $\mathrm{PhD}$ in his lab and work on this very interesting project. It has been my great honor to do my PhD thesis under his supervision. I am very grateful to Prof. Rüdiger Behr for all the support and advice during these years. This work would not have succeeded without his excellent supervision and scientific management, which has always been an inspiration to me.

I am grateful to Prof. Sigrid Hoyer-Fender for accepting to be my official supervisor for my $\mathrm{PhD}$. I am honored to have Prof. Sigrid Hoyer-Fender and Prof. Lutz Walter as members of the PhD committee, and I would like to thank for their helpful comments and friendly advice on the project during the progress reports.

I would like to thank my reviewer's committee members Prof. Dr. Michael Kessel, PD Dr. Halyna Shcherbata, Dr. Antje Engelhardt and Dr. Nikola-Michael Prpic-Schäper.

I am very thankful to Dr. Gabriela Salinas-Raster's lab from Microarray and Deep-Sequencing Core Facility, University Medical Center Göttingen (UMG) for transcriptome analysis. Many thanks to Prof. Michael Heistermann from Endocrinology Laboratory, German Primate Center for performing the hormonal assay and Prof. Ralf Dressel from Department of Cellular and Molecular Immunology, University of Göttingen for conducting the teratoma assay.

I would like to express my immense gratitude to DAAD (German Academic Exchange) Service to support me during these years to peruse my $\mathrm{PhD}$ in Germany. 
I greatly appreciate our secretary Mrs. Ellen Wiese for all her help and supports during these years.

I am thankful to our kind and experienced veterinarian Dr. Charis Drummer for providing me with fresh monkey's samples. I also would like to thank the pathology group and the marmoset monkey facility of the German Primate Center.

Very special thanks to Nicole, Angelina and Simone for their excellent assistance.

I express my sincere gratitude to all of my current and former lab mates in Prof. Rüdiger Behr's lab for providing a very professional and friendly environment. Special thanks to Nelia and Dr. Katharina Debowski.

I would also like to thank my friend Adeelia Goffe for proof reading this $\mathrm{PhD}$ thesis.

Finally, I would never be able to conclude my $\mathrm{PhD}$ without the continuous support and helps of my kind parents, family and friends. 


\section{Abbreviations}

${ }^{\circ} \mathrm{C}$

$\%$

$\mu \mathrm{g}$

$\mu 1$

$\mu \mathrm{m}$

$\beta-\mathrm{ME}$

BSA

C1

C2

cDNA

$\mathrm{Cm}$

$\mathrm{Cj}$

DAB

DAPI

DAZL

DMEM

DNA

DNase

DPPA3 (STELLA)

EIA

ESC/ ES cell

ESM

et al.
Degree Celsius

percent

microgram

microlitre

micrometer

$\beta$-Mercaptoethanol

Bovine serum albumin

first condition

second condition

complementary DNA

centimeter

Callithrix jacchus

3, 3'-Diaminobenzidine

4', 6-diamidino-2-phenylindole

deleted in azoospermia-like

Dulbecco's Modified Eagle Medium

deoxyribonucleic acid

deoxyribonuclease

developmental pluripotency associated 3

enzyme immunoassay

embryonic stem cell

embryonic stem cell medium

et alii 


\begin{tabular}{ll} 
FBS & fetal bovine serum \\
FGSCs & female germline stem cells \\
FSH & follicle-stimulating hormone \\
FSHR & follicle-stimulating hormone- receptor \\
g & gram \\
GAPDH & glycerinaldehyde 3-phosphat dehydrogenase \\
GCNA & germ cell nuclear antigen \\
h & hours \\
ICZ & Indifferent Cortical Zone \\
Ig & Immunoglobulin \\
IHC & immunohistochemistry \\
LH & luteinizing hormone \\
LH/CGR & luteinizing hormone/choriogonadotropin receptor \\
LHR & luteinizing hormone receptor \\
LIF & leukemia inhibitory factor \\
LIN28 & Abnormal cell lineage protein 28 \\
MEF & mouse embryonic fibroblasts \\
ml & milliliter \\
mM & millimolar \\
mRNA & messenger ribonucleic acid \\
MVH & mouse Vasa homolog \\
NANOG & Tír na nÓg - "land of the ever young” \\
NHP & Non-human primate \\
OCCs & nell colonies \\
\hline
\end{tabular}




\begin{tabular}{ll} 
OCT4( POU5F1) & Octamer binding transcription factor 4 \\
OLCs & oocyte-like cells \\
OSCs & oogonial stem cells \\
OSE & ovarian surface epithelium \\
P & passage \\
PBS & phosphate-buffered saline \\
PCA & principal component analysis \\
PCNA & proliferating cell nuclear antigen \\
PCR & polymerase chain reaction \\
PCT & primitive cortical tissue \\
PGC & primordial germ cell \\
PFA & Paraformaldehyde \\
PRDM & (PR)-domain containing (PRD) transcriptional regulator \\
RNA & real-time quantitative polymerase chain reaction \\
RT & ribonucleic acid \\
RT-qPCR & reverse transcriptase \\
VAL4 & Dalike protein 4 \\
\hline
\end{tabular}




\section{Abstract}

Oogonia are the proliferating diploid germ cells within the female gonad giving rise to oocytes. Oocytes are the meiotic female germ cell stages. In humans, almost all oogonia enter meiosis between weeks 9 and 22 of prenatal development. As a consequence, neonatal human ovaries generally lack oogonia. The same was found in neonatal ovaries of the rhesus monkey, a representative of the old world monkeys (Catarrhini). In the present study we used the common marmoset monkey (Callithrix jacchus) as a representative of the new world monkeys (Platyrrhini). In the first part of the study we could show that the neonatal marmoset monkey ovary has an extremely immature histological appearance compared with human and rhesus monkey ovaries. It contains numerous oogonia expressing the pluripotency factors OCT4A, SALL4, and LIN28. These cells also express the proliferation marker Ki-67, which has previously been shown in human ovary to be restricted to fetal premeiotic germ cells. Together, these data demonstrate the primitiveness of the neonatal marmoset ovary compared with human. This part of the study may introduce the marmoset monkey as a suitable non-human primate model to experimentally study aspects of primate primitive gonad development, follicle assembly, and germ cell biology in vivo.

In the second part of the study we aimed at culturing marmoset female germline stem cells (FGSCs) from neonatal ovaries. We successfully established ovarian cell cultures for more than 20 passages and 5 months. Importantly, comparative transcriptome analysis of the early passages with reference samples including native neonatal ovary and embryonic stem cells revealed a lack of germ cell and pluripotency genes indicating the immediate loss of the typical germ cell populations in culture. However, from passage 4 onwards, the cultured cells produced oocyte- 
like cells under a specific cell culture condition, while oocyte-like cells did not develop under embryonic stem cell conditions. Oocyte-like cells were free-floating, approximately $50 \mu \mathrm{m}$ in diameter and strongly expressed several germ cell markers. The cultured ovarian cells did not develop treratoma or ovarian-like tissues after transplantation into immuno-deficient mice. In summary, our novel primate ovarian cell culture initially lacked germ cells, but then recovered germ cell expression and produced oocyte-like cells. This suggests the presence of FGSCs in the cultures. However, their identity needs to be determined, but we hypothesize that FGSCs lack the typical germ cell signature.

The presence of functional FGSCs in the postnatal primate ovary of the common marmoset monkey could have important implications for the development of possible novel strategies for the protection and preservation of human female fertility during the treatment of cancer and other conditions using chemo- and radiation therapy. 


\section{Introduction}

\subsection{The female reproductive tract}

The female reproductive tract consists of two ovaries, two oviducts (uterine tubes), the uterus, the vagina, and the external genitalia. Its function is to produce female gametes (mature oocytes) and to hold a fertilized oocyte during its complete development thorough embryonic and fetal stages until birth (Junqueira Basic Histology, 11th Edition). The ovaries contain the germ cells and support them during their development and maturation.

\subsection{Development of the premeiotic ovarian germ cell population}

Around the end of the first month of human embryonic development a small population of primordial germ cells (PGCs) migrates from the yolk sac to the gonadal primordium (genital ridge). In mammals, the development of an ovary depends on the presence of two $\mathrm{X}$ chromosomes as sex chromosomes. Ovarian development is initiated by the development of (pre-) granulosa cells. In contrast, male-specific (pre-) Sertoli cells develop, when an X and a Y chromosome are present. After colonization of the female genital ridge, the former PGCs are called oogonia. They divide mitotically and still lack follicular cells. The first human oogonia enter meiosis during embryonic week nine (Bendsen et al., 2006). During weeks 10-12 of human ovarian development oogonia constitute $50-60 \%$ of all ovarian germ cells. During weeks 12-18 most germ cells enter into meiosis and convert to oocytes. Oogonia and oocytes can be cytologically distinguished based on their nuclear structure especially based on synaptonemal

complex formation of meiotic prophase (Maheshwari \& Fowler 2008). The large majority of 
oogonia in human ovaries enter meiosis before birth (Stoop et al., 2005; Bendsen et al., 2006). Byskov and colleagues reported that oogonia are only very rarely present in peri- and postnatal human ovaries (Byskov et al., 2011). ). In a previous histological study no oogonia were detected in neonatal human and macaque ovaries (van Wagenen \& Simpson 1973).

\subsection{Histology of the adult human ovary}

Human ovaries are almond-shaped bodies about $3 \mathrm{~cm}$ long, $1.5 \mathrm{~cm}$ wide and $1 \mathrm{~cm}$ thick. Their surface is covered by a simple squamous or cuboidal epithelium, the so-called germinal epithelium. The cortical region contains ovarian follicles. An ovarian follicle consists of an oocyte which is surrounded by one or more layers of follicular cells, which are also called granulosa cells. The follicles that are formed by an oocyte surrounded by a single layer of flattened follicular cells are primordial follicles. The oocytes in the primordial follicles are spherical cells with a diameter of about $25 \mu \mathrm{m}$. Their nuclei are large and have a large nucleolus. These cells are in the first prophase of meiosis. The inner most part of the ovary is the medullary region, containing a rich vascular bed within a loose connective tissue (Junqueira Basic Histology, 11th Edition).

\subsection{Folliculogenesis}

Beginning in puberty, small groups of primordial follicles start folliculogenesis. This is the process of follicular growth from small primordial follicles up to mature preovulatory follicles. This growth process comprises modifications of the oocyte, the granolusa cell and the stromal fibroblasts that surround the follicles. It is not known how the particular follicles, which enter 
folliculogenesis, are selected from the large population of primordial follicles. Follicular growth is stimulated by Follicle-Stimulating Hormone (FSH), secreted by the pituitary. During folliculogenesis, human oocytes reach a maximum diameter of about 120 $\mu$ m (Junqueira Basic Histology, 11th Edition). When follicles enter the growth phase, they enlarge both by proliferation of granulosa cells and by an increase in size of the oocytes. A zona pellucida begins to be laid down around the oocytes shortly after initiation of follicular growth. Progressively, follicles become secondary follicles (preantral follicles). At this stage of development, some stromal cells near the basal lamina become aligned parallel to each another, then antral follicles (tertiary follicles) and finally preovulatory and Graafian follicles are formed (Gougeon, 1996). During each menstrual cycle, usually one follicle grows to a bigger size than the others of the same cohort and becomes the dominant follicle, from which the mature egg is ovulated in response to a LH surge. The LH is, like FSH, a glycohormone released from the pituitary. At the peak of its development this follicle is so large in humans (about $2.5 \mathrm{~cm}$ in diameter) that it protrudes from the surface of the ovary and can be easily detected by ultrasound. The whole process of follicular growth from primordial to mature follicle lasts about 90 days in humans (Junqueira Basic Histology, 11th Edition).

\subsection{Central dogma of reproductive biology}

Oogonia are the intragonadal female germ line progenitor cells, which give rise to meiotic oocytes. Oogonia are characterized by diploidy and mitotic proliferation. Since the 1950s it is dogma in reproductive biology that in females of most mammalian species, oogonia exist only during fetal development (Zuckerman et al., 1951). Zuckerman revealed by detailed histological and morphological studies in rats (and also other adult mammalian ovaries) that oocytes were not 
produced during the whole life span of an animal. Instead, females are born with a nonrenewable pool of follicles which declines with age (Byskov et al., 2005, Telfer et al., 2005). In contrast to the female gonad, it is generally accepted that in the male gonad germline stem cells, called spermatogonial stem cells, fuel spermatogenesis and gamete production over the life time of the animal. Hence, there appear to be fundamental differences between the male and the female mammalian gonad regarding the strategies to provide fertilization-competent gametes (Borum, 1961; Peters, 1970; McLaren, 1984; Anderson and Hirshfield, 1992). In favor of dogma, Liu and colleagues (Liu et al. 2007) showed that adult human ovaries do not express genes specific for the early phases of meiosis, which is in contrast to fetal ovaries, where early-stage meiosis genes can be detected. In contrast to mammals, neo-oogenesis (the production of new oocytes during female adult life) starting from germline stem cells is commonly occurring in "lower" animals such as flies, fish and birds. Liu and colleagues reported that there are no oogonia or oogonium-like cells in adult human ovaries that can contribute to neo-oogenesis (Liu et al., 2007). Another recent study by Yuan and colleagues (Yuan et al. 2013) also failed to provide evidence for proliferative germ cells in adult monkey and mouse ovaries. However they found proliferating non-germline, i.e. somatic stem cells (Yuan et al., 2013). These studies indicated that the oocyte population is fixed in those species investigated. However, exceptions to this have been found more than 40 years ago in some rarely studied species of prosimian primates, where the presence of mitotically proliferating germ cells in the adult ovary has been shown (Gerrad, 1920; Ioannou, 1967). However, the prosimians, which are considered as a rather primitive group of primates, are currently not studied anymore in reproductive biology. 


\subsection{Renewal of germ cells after birth (Neo-oogenesis in postnatal mammalian ovary)}

The central reproductive biology dogma of a fixed germ cell pool in the mammalian ovary has been challenged during recent years. In 2004, Jonathan Tilly's group reported the presence of ovarian germline stem cells or oogonial stem cells (OSCs) in postnatal female mouse ovaries. These OSCs are reported to be mitotically active germ cells expressing the Mouse Vasa Homolog (MVH), a conserved germ cell specific marker. OSCs can generate oocytes under experimental conditions (Johnson et al., 2004, 2005). Another study by Kerr and colleagues using immunolabelling of germ cell nuclear antigen (GCNA) and proliferating cell nuclear antigen (PCNA) revealed that there is postnatal renewal of follicles in adult mouse ovaries (Kerr et al., 2006). Probably the strongest evidence so far for germline stem cells in the postnatal ovary was provided by Zou and colleagues (Zou et al., 2009). They could generate female germline stem cells (FGSCs) from neonatal mouse ovaries with the ability to regenerate oogenesis after transplantation into chemically sterilized recipient ovaries and to produce offspring. White and colleagues also reported rare mitotically active germ cells in ovaries of reproductive-age women. These cells could generate oocytes (or oocyte-like cells) in vitro and in vivo (White et al., 2012).

\subsection{The origin of germline stem cells}

It still remains unclear whether germline stem cells, if they exist, originate from ovarian surface epithelium (OSE) or even from bone marrow, as suggested by Johnson et al (2005). In adult human ovaries the OSE is suggested to be a source of germ cells (Bukovsky et al., 1995). In vitro studies suggested that the OSE is a potential source of both oocytes and granulosa cells (Bukovsky et al., 2005). Parte et al. 2011 reported the production of oocyte-like cells in vitro 
from cultures of adult OSE (Parte et al., 2011). Johnson and colleagues (2005) suggested that bone marrow may serve as a source of cells responsible for this regenerative capacity (Johnson et al., 2005).

\subsection{The common marmoset monkey (Callithrix jacchus)}

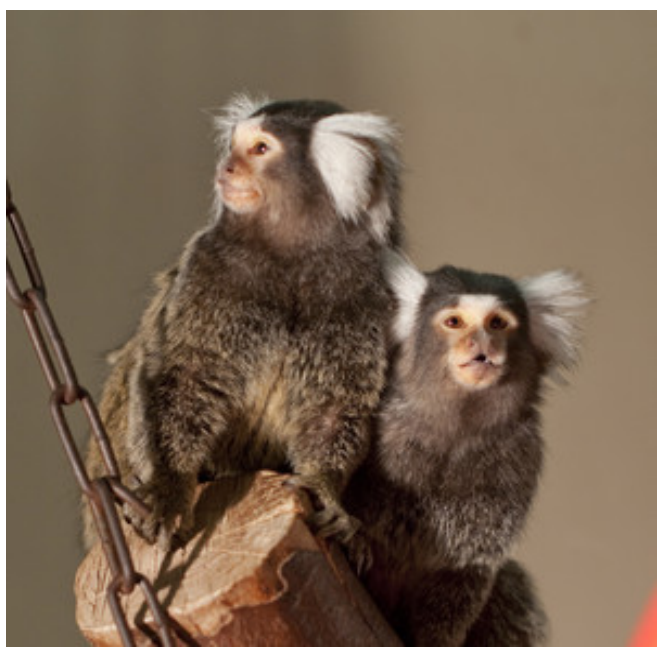

Figure 1 Common marmoset monkey (Callithrix jacchus) (DPZ archive)

The common marmoset monkey (Callithrix jacchus) is a new world monkey which is native to Brazil. The body size is small compared to other primates and is only around $25 \mathrm{~cm}$ in length (excluding the tail). The body weight is around $300-450$ g. These characteristics make marmoset monkeys an easy-to-handle animal model. High reproductive success and absence of reproductive seasonality are key characteristics making marmoset monkeys a very valuable model to study nonhuman primate reproductive physiology and stem cells (Hearn 1983, Mansfield 2003, Sasaki et al. 2005, Chandolia et al. 2006, Luetjens et al. 2008, Mitchell et al. 2008, McKinnell et al. 2009, Sasaki et al. 2009, Albert et al. 2010,Beindorff \& Einspanier 2010, von Schonfeldt et al. 2011, Aeckerle et al. 2012, Hanazawa et al. 2012, Lin et al. 2012, Tomioka et al. 2012, McKinnell et al. 2013, Parte et al. 2013). However, research on gonadal development focused to our knowledge mostly on testicular development ( $\mathrm{Li}$ et al. 2005, Chandolia et al. 2006, Mitchell et al.2008, McKinnell et al. 2009, Albert et al. 2010, Aeckerle et al. 2012, Eildermann et al. 2012, Lin et al. 2012, McKinnell et al. 2013). In this study, we investigated the ovarian development of the common marmoset monkey. 


\subsection{Aims of the Study}

The purpose of this $\mathrm{PhD}$ project is to provide evidence for or against the presence of oogonia with germline stem cell function in the postnatal ovary of the common marmoset monkey. There are two specific aims: (i) to study and describe the ovarian histology and the germ cell population of the neonatal common marmoset monkey (Callithrix jacchus) and (ii) to culture and characterize postnatal marmoset monkey premeiotic ovarian germ cells. The first aim was approached by performing histological and immunohistochemical studies through in situ identification and characterization of oogonia or putative ovarian germline stem cells in the postnatal ovary of the common marmoset monkey. The second aim was tested by the establishment of a long-term culture system for putative germline stem cells which could generate oocyte-like cells (OLCs) in vitro and subsequent characterization the OLCs and the cultured ovarian cells. 


\section{Original Publications in peer-reviewed journals}

This dissertation is based on the following original articles

1- Bentolhoda Fereydouni, Charis Drummer, Nelia Aeckerle, Stefan Schlatt, and Rüdiger Behr. The neonatal marmoset monkey ovary is very primitive exhibiting many oogonia, Reproduction. 2014 May 19. pii: REP-14-0068. [Epub ahead of print].

http://www.ncbi.nlm.nih.gov/pubmed/24840529

2- Bentolhoda Fereydouni, Gabriela Salinas-Riester, Michael Heistermann, Ralf Dressel, Lucia Lewerich, Charis Drummer, and Rüdiger Behr. Long-term oocyte-like cell development in cultures derived from neonatal marmoset monkey ovary. Submitted to STEM CELLS. 


\title{
The neonatal marmoset monkey ovary is very primitive exhibiting many oogonia
}

\author{
B. Fereydouni ${ }^{1}$, C. Drummer ${ }^{1}$, N. Aeckerle ${ }^{1}$, S. Schlatt ${ }^{2}$, and R. Behr ${ }^{1}$ \\ Stem Cell Biology Unit, German Primate Center - Leibniz Institute for Primate Research, \\ Kellnerweg 4, 37077 Göttingen, Germany \\ Centre of Reproductive Medicine and Andrology, University of Münster, Domagkstraße 11, \\ 48149 Münster, Germany
}

\section{Corresponding author's address:}

Rüdiger Behr

German Primate Center

Stem Cell Biology Unit

Kellnerweg 4

D-37077 Göttingen

Germany

Fon: ++49 551-3851-132

Fax: ++49 551-3851-288

Email: rbehr@dpz.eu

Short title: Oogonia in postnatal primate ovary

Key words: Germ cell / Non-human primate / Oogonia / Ovary / Pluripotency factor 


\begin{abstract}
Oogonia are characterized by diploidy and mitotic proliferation. Human and mouse oogonia express several factors such as OCT4, which are characteristic of pluripotent cells. In the human, almost all oogonia enter meiosis between the $9^{\text {th }}$ and $22^{\text {nd }}$ week of prenatal development or undergo mitotic arrest and subsequent elimination from the ovary. As a consequence, neonatal human ovaries generally lack oogonia. The same was found in neonatal ovaries of the Rhesus monkey, a representative of the old world monkeys (Catarrhini). In contrast, proliferating oogonia were found in adult prosimians (now called Strepsirhini), which is a group of "lower" primates. The common marmoset monkey (Callithrix jacchus) belongs to the new-world monkeys (Platyrrhini) and is increasingly used in reproductive biology and stem cell research. However, ovarian development in the marmoset monkey has not been widely investigated. Here we show that the neonatal marmoset ovary has an extremely immature histological appearance compared with the human ovary. It contains numerous oogonia expressing the pluripotency factors OCT4A, SALL4, and LIN28. The pluripotency factor-positive germ cells also express the proliferation marker Ki-67, which has previously been shown in the human ovary to be restricted to premeiotic germ cells. Together, the data demonstrate the primitiveness of the neonatal marmoset ovary compared to the human. This study may introduce the marmoset monkey as a non-human primate model to experimentally study aspects of primate primitive gonad development, follicle assembly, and germ cell biology in vivo.
\end{abstract}




\section{Introduction}

Primates can be subdivided into two large groups: Stepsirhini (the former group of prosimians excluding tarsiers) and Haplorhini (the former group of simians plus tarsiers) (Finstermeier et al. 2013). The old term simian has been replaced by Anthropoidea (i.e. Haplorhini without tarsiers). Anthropoidea include Platyrrhini (new world monkeys) and Catarrhini (old world monkeys and Hominoidea, which include humans, great apes, and gibbons) (Perelman et al. 2011, Finstermeier et al. 2013). The Stepsirhini are a group of primates with characteristics often considered rather primitive compared to Anthropoidea. Old world monkeys are native to Asia and Africa, while the new world monkeys are native to America. In the human, a representative of the Catarrhini, the adult ovary provides the gametes from a fixed pool of germ cells that was established during the fetal phase of ovary development (Hartshorne et al. 2009), and there is evidence that there is no germ cell proliferation in the normal postnatal human (Stoop et al. 2005, Liu et al. 2007, Byskov et al. 2011) and old world monkey ovary (Yuan et al. 2013). In sharp contrast, studies carried out more than 40 years ago show the presence of mitotically proliferating germ cells in the ovary of even adult Strepsirhini (Ioannou 1967, Butler \& Juma 1970). In the human ovary, the first oogonia enter meiosis during embryonic week nine (Bendsen et al. 2006). During weeks 10-12 of ovarian development oogonia constitute $50-60 \%$ of all ovarian germ cells (Maheshwari and Fowler (2008). During weeks 12-18 the number of oocytes increases reflecting entry into meiosis of most germ cells (Maheshwari \& Fowler 2008). The vast majority of oogonia had entered meiosis by the end of the second trimester (Stoop et al. 2005, Bendsen et al. 2006), so that already the late fetal human ovary contains almost only proliferation-arrested germ cells. Recently, Byskov et al (2011) reported that oogonia are very rarely present in peri- and postnatal human ovaries, and in previous histological analyses no 
oogonia were found in neonatal human and macaque ovaries (van Wagenen \& Simpson 1973). Oogonia and oocytes can be cytologically distinguished based on their contour in histological sections and their nuclear structure (Maheshwari \& Fowler 2008). Particularly, synaptonemal complex formation is a major hallmark of meiotic prophase (Maheshwari \& Fowler 2008). On the molecular level, it has been shown in the human fetus that specifically premeiotic germ cells (primordial germ cells and oogonia and gonocytes, respectively) maintain the expression of some pluripotency markers whose expression is otherwise restricted to the inner cell mass of preimplantation embryos and to ex vivo cultured pluripotent stem cells (Kerr et al. 2008, Perrett et al. 2008, Childs et al. 2012).

In the present study we used the common marmoset monkey (Callithrix jacchus) as a representative of the new world monkeys (Platyrrhini) to study its germ cell population in the immature ovary. The body size of only around $25 \mathrm{~cm}$ and a weight of 300-450 g make marmoset monkeys an easy-to-handle-animal model yet representing primate physiology and biology. High reproductive success and absence of reproductive seasonality are key characteristics making marmoset monkeys a very valuable model to study non-human primate (NHP) reproductive physiology and stem cells (Harlow et al. 1983, Mansfield 2003, Sasaki et al. 2005, Chandolia et al. 2006, Luetjens et al. 2008, Mitchell et al. 2008, McKinnell et al. 2009, Sasaki et al. 2009, Albert et al. 2010, Beindorff \& Einspanier 2010, von Schonfeldt et al. 2011, Aeckerle et al. 2012, Hanazawa et al. 2012, Lin et al. 2012, Tomioka et al. 2012, McKinnell et al. 2013, Parte et al. 2013). However, research on marmoset gonadal development has only been focused to our knowledge on the male (Li et al. 2005, Chandolia et al. 2006, Mitchell et al. 2008, McKinnell et al. 2009, Albert et al. 2010, Aeckerle et al. 2012, Eildermann et al. 2012, Lin et al. 2012, 
McKinnell et al. 2013). Consequently, almost nothing is known about the characteristics of the neonatal marmoset monkey ovary.

In the present study we used five protein markers, namely, OCT4A (also called POU5F1), SALL4, LIN28, VASA (also called DDX4) and Ki-67, to study the germ cell population in the marmoset monkey ovary. The OCT4A-isoform of the OCT4 gene is germline-specific and is one of the most specific and indicative markers of pluripotency (Scholer et al. 1990, Liedtke et al. 2008, Wang \& Dai 2010). OCT4 is important for mouse primordial germ cell survival (Kehler et al. 2004) and was also used to study human germ cell development (Stoop et al. 2005, Perrett et al. 2008, Byskov et al. 2011, Childs et al. 2012, Mamsen et al. 2012). The transcription factor SALL4 is essential for pluripotency of mouse ES cells (Elling et al. 2006). Mouse spermatogonia also critically depend on SALL4 function (Hobbs et al. 2012). We demonstrated that SALL4 protein expression is restricted to premeiotic germ cells in the human and non-human primate testis including the common marmoset monkey testis (Eildermann et al. 2012). The RNAbinding pluripotency-associated protein LIN28 is expressed in marmoset monkey ES cells and in human and monkey male premeiotic germ cells (Aeckerle et al., 2012, Vogt et al. , 2012). In the human ovary, LIN28 has been shown to be a specific marker of oogonia (Childs et al. 2012). The functional importance of LIN28 for the formation of mouse germ cells has also been demonstrated (West et al. 2009). VASA is a germ line-specific RNA helicase that is expressed in most intragonadal stages of male and female human germ cell development from premeiotic up to the postmeiotic stages (Castrillon et al. 2000, Anderson et al. 2007). However, first trimester human gonocytes and oogonia generally lacked VASA (Anderson et al. 2007).

Ki-67 protein is a nuclear protein, which is present during the G1, S, G2, and M-Phase of the cell cycle but absent from resting cells in G0 phase. Hence, Ki-67 specifically marks the proliferative 
cell population in a given tissue and represents one of the most reliable proliferation markers (Scholzen \& Gerdes 2000). In human ovarian germ cells, Ki-67 is strongly expressed by oogonia, while oocytes were generally negative for Ki-67 (Stoop et al. 2005). Only occasionally few oocytes engaged in primordial follicles showed some Ki-67 signals, which were strictly confined to the nucleolus. Therefore, in the human, nuclear Ki-67-positive ovarian germ cells in the represent oogonia.

The aims of this study were (i) to describe marmoset monkey ovarian histology at birth and (ii) to characterize the germ cell population in the neonatal ovary of the common marmoset monkey with regard to the presence of oogonia. We show that the neonatal marmoset ovary is, compared to the human, extremely primitive at birth since it contains numerous premeiotic germ cells. Therefore, the postnatal marmoset ovary may represent a useful NHP model to experimentally study phases of female gonadogenesis, which in humans occur during intrauterine embryonic / fetal development, which is experimentally inaccessible. 


\section{Materials and methods}

\section{Animals}

Common marmoset monkeys (Callithrix jacchus) were studied. Monkeys were housed in a selfsustaining colony at the German Primate Center (Deutsches Primatenzentrum; DPZ) according to standard housing for marmoset monkeys. The institutional guidelines of the DPZ for the care and use of marmoset monkeys were strictly followed. According to applicable law no separate license is necessary to harvest organs after killing of the animals. Neonatal female common marmoset monkeys (age 1-5 days) were obtained from the breeding colony of the German Primate Center (Göttingen, Germany). The marmosets were housed as breeding pairs. In captivity, they often give birth to triplets or even quadruplets. However, the mother is usually able to feed and rear only two neonates, which is the normal litter size in free-living marmosets. Therefore, the female neonates from triplet or quadruplet births were used to collect organs for this study. The marmosets were housed in a temperature- $\left(25 \pm 1^{\circ} \mathrm{C}\right)$ and humidity-controlled (65 $\pm 5 \%$ ) facility. The light:dark cycle was 12:12 hours. The animals were fed ad libitum with a pelleted marmoset diet. In addition, $20 \mathrm{~g}$ mash per animal was served in the morning and $30 \mathrm{~g}$ cleanly cut fruits or vegetables mixed with noodles or rice were supplied in the afternoon. Drinking water was also available ad libitum.

\section{Numbers of animals}

Six neonatal marmoset ovaries from four different animals in the age range of postnatal day 1-5, one one-year-old marmoset ovary, four adult ovaries from three different animals, and one fetal ovary was used in this study. 


\section{Retrieval of tissues}

Neonatal marmoset monkeys were obtained from the DPZ breeding colonies and anaesthetized with Pentobarbital (Narcoren ${ }^{\circledR}$; $0.05 \mathrm{ml}$ intramuscular) and then euthanized with an intracardial injection of $0.5 \mathrm{ml}$ Pentobarbital. Neonatal marmosets were selected from triplet births based on the changes in body weight of the neonates. The ones that had lowest birth weight or the one that lost most weight during the first 1-5 postnatal days due to the inability of the mother to nourish three offspring were selected for euthanasia. All animals were euthanized before a lack of nourishment caused suffering of the animals. The one-year-old ovary was obtained from the DPZ pathology unit. The animal was euthanized due to a reason unrelated to reproductive functions and the ovary was made available to this study. Ovaries from adult females were available from the histological archive of the DPZ. The fetal ovary (calculated gestational day 90; total period of gestation is around 144 days in marmoset monkeys; (Chambers \& Hearn 1979)) was obtained from a fetus from the breeding colony of the Centre for Reproductive Medicine and Andrology (CeRA) of the University Hospital Münster. The fetus was recovered from the uterus of a pregnant female after sacrifice of the female (license number 8.87-50.10.46.09.018). The age of the fetus was calculated around gestational day 90 . This was based on the breeding history of the female and on the development of the fetus in comparison with other fetuses obtained from timed pregnancies in another study. The normal period of gestation of marmosets is 143 days.

\section{Histology and immunohistochemistry}

Ovaries and the fetus were immediately fixed in Bouin's solution, further processed according to routine histological techniques and eventually embedded in paraffin for immunohistochemical analysis. Serial sections (5 $\mu \mathrm{m})$ were done and placed on adherent slides. Paraffin sections were 
de-waxed, rehydrated. Antigen retrieval was carried out with the $10 \mathrm{mM}$ Na- Citrate buffer $\mathrm{pH}$ 6.0 for 10 minutes in high powermicrowave. Paraffin sections were washed for 5 minutes in 0.05 M Tris wash buffer. Then blocking of peroxidase was done for 15 minutes with the Peroxidase block (DAKO). After washing again with washing buffer, immunostainings were done with OCT4A (\#2890S, Cell signaling Technology) (1:100), LIN28 (\#3978S, Cell signaling Technology) (1:100 - 1:200), SALL4 (\#ab57577, Abcam) (1:200), VASA (DDX4; \#AF2030, R\&D systems) (1:100), Ki67 (\#9027S, Cell signaling Technology) (1:300). The antibodies were also used in previous studies (Aeckerle et al. 2012, Eildermann et al. 2012, Aeckerle et al. 2013) and were found to be valid for the detection of the respective marmoset monkey proteins. Primary antibodies were diluted with washing buffer plus 5\% BSA. Sections were incubated with the primary antibodies at $4{ }^{\circ} \mathrm{C}$ overnight. The primary antibodies were detected using DAKO LSAB+ system- HRP kit (\#K0679). Sections were visualized with the chromogen DAB that showed brown signals. Mayer's Hematoxylin staining was used as counterstain. Negative controls were performed by omitting primary antibodies and by using corresponding nonspecific immunoglobulin controls instead of the specific primary antibody. Double-staining was performed using DAKO EnVision ${ }^{\mathrm{TM}}$ G|2 Double stain System, Rabbit/Mouse (DAB+/Permanent Red) kit (ordering number K5361) according to the manufacturer's protocol. The photos were captured with a ZEISS Axiophot microscope equipped with a Nuance camera, which is a multispectral camera enabling imaging of multiple markers on tissue sections also in brightfield microscopy and even when the signals co-localize. 


\section{Quantitive Reverse Transcriptase Polymerase Chain Reaction (RT-qPCR)}

RT-qPCR for a pluripotency marker (OCT4A, POU5F1), pluripotency/germ cell markers (LIN28, SALL4) and a germ cell marker (VASA; DDX4) were performed ( $\mathrm{n}=3$ independent PCR runs with all samples). Primers are listed in Table 1. Total RNA from newborn ovaries $(\mathrm{n}=5)$, different passages of an embryonic stem cell line (n=4; ES cell line Cjes001) and from different passages of fibroblasts derived from one primary culture $(n=4)$ of the common marmoset monkey were extracted using QIAGEN RNeasy Mini Kit according to manufacturer's instructions. RNA samples were treated with DNase I to digest contaminating DNA. Complementary DNA (cDNA) was produced from $1 \mu \mathrm{g}$ RNA using the QIAGEN Omniscript reverse transcriptase kit. The Master mix for every reaction consisted of: $2 \mu l$ 10x Buffer, $2 \mu l$ dNTPs, $2 \mu$ l Oligo-dt and $1 \mu$ l reverse transcriptase in a final volume $20 \mu$ l. Reverse transcription was conducted at $37{ }^{\circ} \mathrm{c}$ for $1.5 \mathrm{~h}$ in the thermocycler (Biometra T3000). The resulting cDNA was diluted 1:5 and was then used as template for each $20 \mu$ PCR reaction with power SYBER Green PCR Master Mix (\#4368706, Applied Biosystem). Appropriate primer concentrations for each primer pair (see table 1) were tested to yield a distinct, single amplicon which was visualized by $2 \%$ agarose gel electrophoresis. Identity of the amplicon was confirmed by DNA sequencing. The qPCR programme consisted of an initial step of denaturation (10 min at $\left.95^{\circ} \mathrm{c}\right)$ followed by 40 cycles of denaturation $\left(15 \mathrm{~s}\right.$ at $\left.95^{\circ} \mathrm{c}\right)$ and annealing / elongation $\left(1 \mathrm{~min}\right.$ at $\left.60^{\circ} \mathrm{C}\right)$. As qPCR controls we included a no- template control (NTC), which contained all real-time PCR components except the template, a -RT (Reverse Transcriptase) control and positive controls (ES cell RNA) to test for the presence of PCR inhibitors. Each sample was assayed in triplicate and normalized to glyceraldehyde-3-phosphate dehydrogenase (GAPDH) expression. The expression level of GAPDH was stable between the samples. Relative quantification was based 
on the method (Livak \& Schmittgen 2001). Statistical analysis (unpaired T-Test) was done with Graphpad Prism software. $\mathrm{P}<0.05$ was considered as statistically significant.

Table 1: Primer sequences, sizes of PCR products and concentrations of primers.

\begin{tabular}{|c|c|c|c|}
\hline Primer & Primer sequence & $\begin{array}{c}\text { PCR } \\
\text { product } \\
\text { size (bp) }\end{array}$ & $\begin{array}{c}\text { Concentration } \\
{[\mathrm{nM}]}\end{array}$ \\
\hline Cj_GAPDH_Fw & 5’-TGCTGGCGCTGAGTATGTG-3’ & 64 & 300 \\
\hline Cj_GAPDH_Re & 5’-AGCCCCAGCCTTCTCCAT-3’ & & 50 \\
\hline Cj_LIN28_Fw & 5’-GACGTCTTTGTGCACCAGAGTAA-3’ & 67 & 300 \\
\hline Cj_LIN28_Re & 5’-CGGCCTCACCTTCCTTCAA-3’ & & 50 \\
\hline Cj_SALL4_Fw & $\begin{array}{l}\text { 5'-AAGGCAACTTGAAGGTTCACTACA- } \\
\text { 3' }\end{array}$ & 77 & 900 \\
\hline Cj_SALL4_Re & 5’-GATGGCCAGCTTCCTTCCA-3’ & & 50 \\
\hline Cj_VASA_Fw & 5'-TGGACATGATGCACCACCAGCA-3' & 210 & 50 \\
\hline Cj_VASA_Re & 5’-TGGGCCAAAATTGGCAGGAGAAA-3’ & & 900 \\
\hline Cj_OCT4A_Fw & 5’-GGAACAAAACACGGAGGAGTC-3’ & 234 & 300 \\
\hline Cj_OCT4_Re & 5’-CAGGGTGATCCTCTTCTGCTTC-3’ & & 50 \\
\hline
\end{tabular}




\section{Results}

\section{Histology of the neonatal marmoset ovary}

Fig.1 A is an overview over a whole cross-sectioned neonatal marmoset monkey ovary. The surface of the neonatal ovary is regular and there is no lobular structure. The entire ovary is covered by the ovarian surface epithelium (OSE). Positioned directly underneath the OSE there is a thin layer of cells in which the different cell types are histologically hardly distinguishable. It contains primitive germ and somatic cells and is shown at higher magnification in Fig.1B. We term this zone indifferent cortical zone (ICZ) of the neonatal marmoset ovary. A typical Tunica albuginea as a connective tissue layer underneath the OSE is not yet established (compare with Fig.3; Histology of 1-year ovary). The next layer and major compartment of the neonatal marmoset ovary is the immature cortex, where the germ cells are still organized in clusters or nests of cells. These germ cell aggregations are "belted" by somatic cells. The central part of the marmoset ovary is constituted by the medulla. The mesovary can be seen in the lower left part of Fig.1A.

At the border between the ICZ and the cortex, there are germ cell nests containing both, germ cells with an oogonia phenotype and germ cells with an oocyte (meiotic) phenotype (Fig.1B). Moreover, there are numerous small nests of cells containing apparently only oogonia. The deeper areas of the cortex contain predominantly cell nests with meiotic germ cells. Few primordial follicles are also present. In order to obtain an overview over the presence and distribution of premeiotic germ cells in the neonatal marmoset ovary, we used LIN28 immunohistochemistry (Fig.1C). The overview of a LIN28-stained ovary indicates an abundance of premeiotic germ cells in the neonatal marmoset ovary. Two characteristics are evident: (i) 
there are huge clusters or nests of oogonia as well as scattered oogonia. (ii) Oogonia are not only present in the very periphery but also in deeper areas of the cortex.

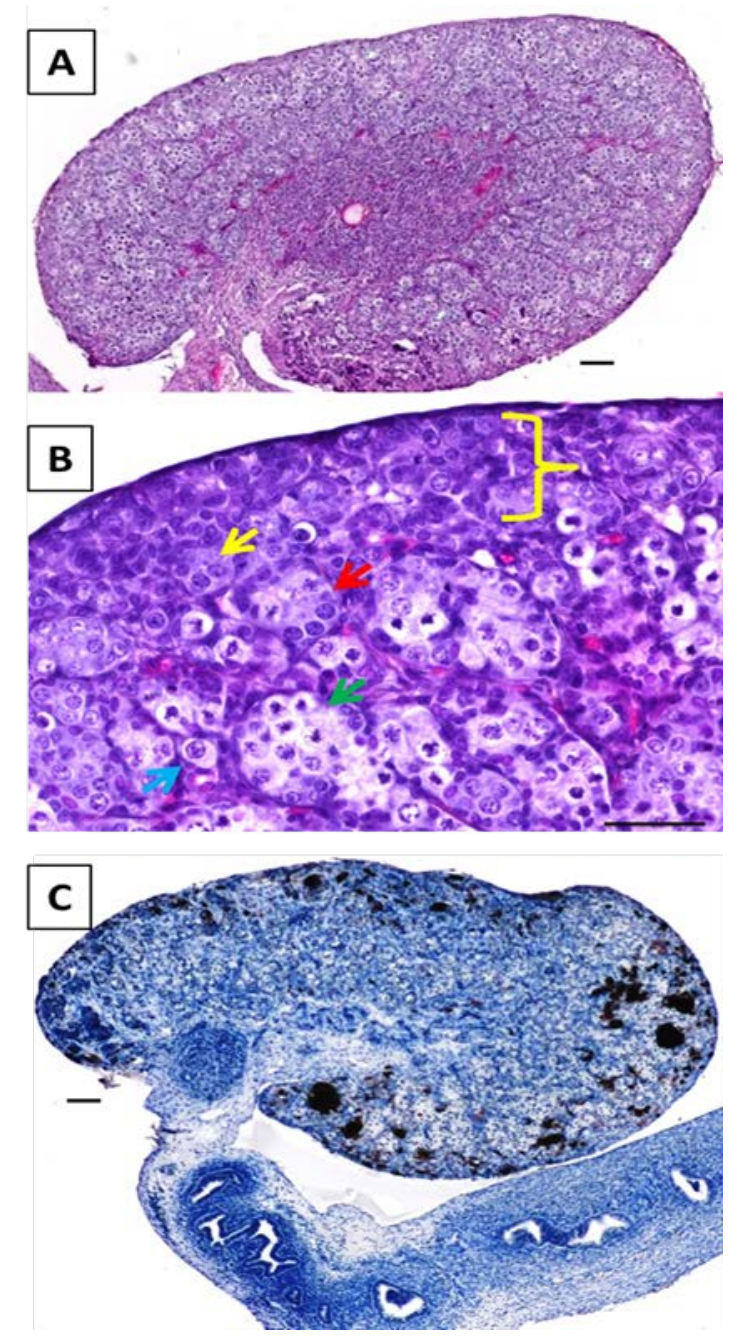

\section{Figure1 Histology of the neonatal marmoset monkey ovary.}

A) Shows an overview of a whole cross section through a neonatal ovary. The central medulla region and the peripheral cortical region can be easily recognized. The whole ovary is covered by the ovarian surface epithelium (OSE). Between the outer zone of the cortex and OSE there is a histological layer which we call indifferent cortical zone (ICZ) of the neonatal marmoset ovary (see also B). At the bottom the hilum / mesovary can be seen. B) Higher magnification of the peripheral zones of the ovary. The dark line covering the tissue represents the flat OSE. The bottom part shows the classical cortical zone characterized by cysts of germ cells and few primordial follicles. The ICZ is indicated by the yellow bracket. A Tunica albuginea, a characteristic sub-ovarian surface epithelium-layer of the adult ovary, is not yet established. Yellow arrow: Nest of oogonia. Red arrow: Nest containing some oogonia and some oocytes. 
Note the different nuclear structure of the germ cells. Green arrow: Nest of oocytes. Blue arrow: Primordial follicle. C) Gives an overview of the distribution of premeiotic germ cells in the neonatal ovary. The brown stain indicates the presence of a specific oogonial marker (LIN28). Stained cells are present in the cortical zone, in the ICZ and in the OSE either as large clusters, smaller groups of cells or as isolated cells (for further details see Figure 3). The different somatic cells of the ovary as well as the different cell types of the oviduct (bottom part of C) are not stained. The scale bars represent $50 \mu \mathrm{m}$.

\section{Substantial presence of pluripotency factor mRNAs in the neonatal ovary}

To corroborate and confirm the expression of LIN28 on the mRNA level, we performed RTqPCR for LIN28 (Fig.2A). Marmoset monkey ES cells and fibroblasts were used as positive and negative controls, respectively. In fibroblasts, LIN28 mRNA was undetectable. In contrast, neonatal ovary exhibited approximately $20 \%$ of the LIN28 transcript levels of ES cells. We further tested the expression of the germ line- and pluripotency-associated factors SALL4 and OCT4A. In fibroblasts, SALL4 mRNA was only very weakly expressed, while OCT4A was undetectable. For SALL4, the ovary had about $60 \%$ of the relative expression level of the ES cells (Fig.2B). For OCT4A (Fig.2C) the corresponding value was around 6\%. As an additional control, we tested the expression of the germ cell gene VASA (DDX4). VASA transcripts were highly abundant in neonatal ovary, while only very low VASA transcript levels were detected in undifferentiated ES cells and fibroblasts (Fig.2D). Since we compared the expression of genes in pure cell populations (ES cells and fibroblasts) with their expression in a tissue containing several cell types (ovary), these data cannot be directly related to a cell-specific expression level in the ovary. However, very importantly, the signals detected in ovary were always significantly above background levels detected in fibroblasts ( $<<0.01)$. In summary, Fig.2 clearly shows that the neonatal marmoset monkey ovary contains substantial transcript amounts not only of VASA, but also of pluripotency markers. 

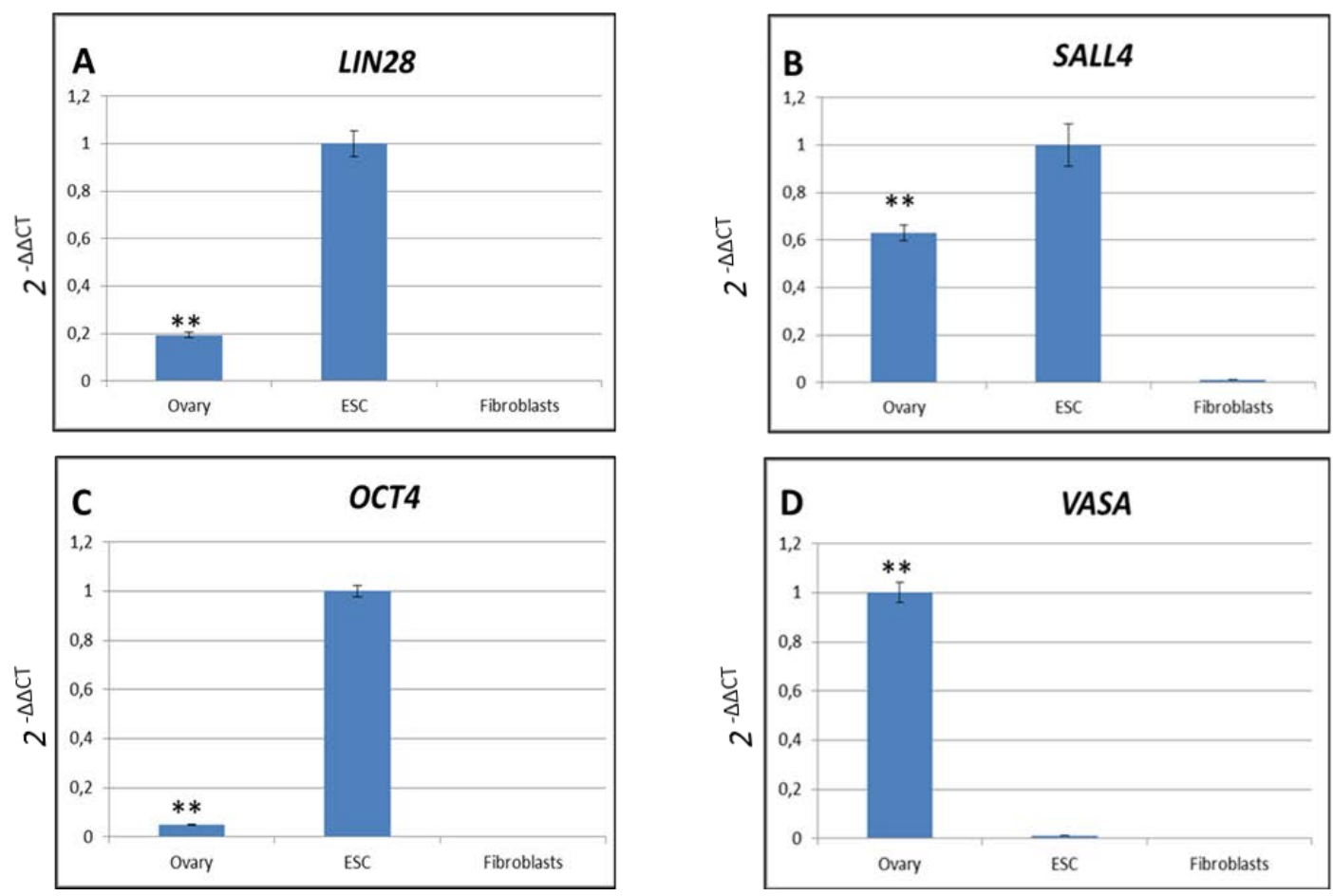

Figure2 Messenger RNA expression of pluripotency and germ cell markers in the neonatal marmoset ovary compared with pluripotent ES cells and fibroblasts. ES cells serve as positive control for pluripotency markers, fibroblasts as negative controls. The value for ovary (VASA) or for ES cells (OCT4A, SALL4, and LIN28) was always set as 1 . ** indicates $\mathrm{p}<0.01$ between ES cells and ovary

\section{Pre- and neonatal ovarian germ cells express pluripotency factors}

In order to analyze the cell-specific distribution of selected pluripotency markers in the neonatal marmoset ovary, we performed immunohistochemistry for OCT4A, SALL4, and LIN28. Additionally, we stained for the general germ cell marker VASA. Staining results of the neonatal ovarian samples are shown in Fig.3. As references, we included one fetal (Fig.3A, E, I, M), one one-year-old (Fig.3D, H, L, P) and three adult ovaries (data not shown). The early fetal ovary contained germ cells in the developing ovarian cortex. The germ cells were mainly present in clusters and expressed OCT4A (Fig.3A). Based on morphology, we found no germ cell in the fetal ovary lacking OCT4A signals. When we tested for SALL4, we again found all germ cells of 
the fetal ovary expressing this transcription factor (Fig.3E). The same was found for LIN28 (Fig.3I) and VASA (Fig.3M). Hence, all three pluripotency factors, OCT4A, SALL4, and LIN28, were robustly expressed by oogonia in the fetal ovary.

In the neonatal ovary many of the germ cells with a nuclear chromatin structure indicating a premeiotic stage were OCT4A-positive (Fig.3B). Those germ cells that entered meiosis lacked OCT4A signals. Somatic cells were also OCT4A-negative. We also detected some structures significantly smaller than regular germ cell nuclei that were strongly positive for OCT4A (Fig.3C, red arrow). The one year old ovary (Fig.3D) and the adult ovaries (not shown) lacked detectable OCT4A. The SALL4 expression pattern also showed very intense signals for premeiotic germ cells in the neonatal ovary (Fig.3F, G). In contrast to OCT4A, weak SALL4 staining was seen also in oocytes in meiotic prophase. Most cells of the OSE were negative for SALL4. However, some of the OSE cells were very intensely stained for SALL4 (Fig.3G). In the one year old ovary SALL4 was basically undetectable (Fig.3H). Applying LIN28 immunohistochemistry, only premeiotic germ cells were labeled. Most of them were still organized in clusters, but some were also present as isolated germ cells (Fig.3J). At some sites the OSE contained several cells being strongly LIN28-positive, while the neighboring cells of the OSE were LIN28-negative (Fig.3K). Older postnatal stages were LIN28-negative (Fig.3L). VASA was detectable in premeiotic as well as in meiotic germ cells (Fig.3M-P). In summary of this part, the neonatal marmoset ovary contains numerous premeiotic germ cells expressing OCT4A, SALL4, and LIN28. Some OSE cells were also positive for SALL4 and LIN28. However, no OCT4A-positive cells were found in the OSE. 


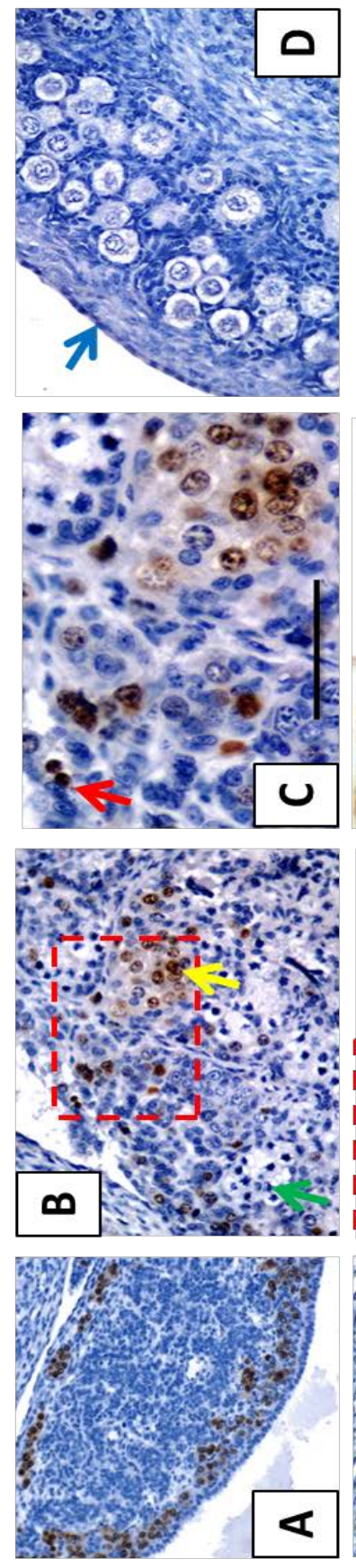

$\forall \bullet \perp \supset O$
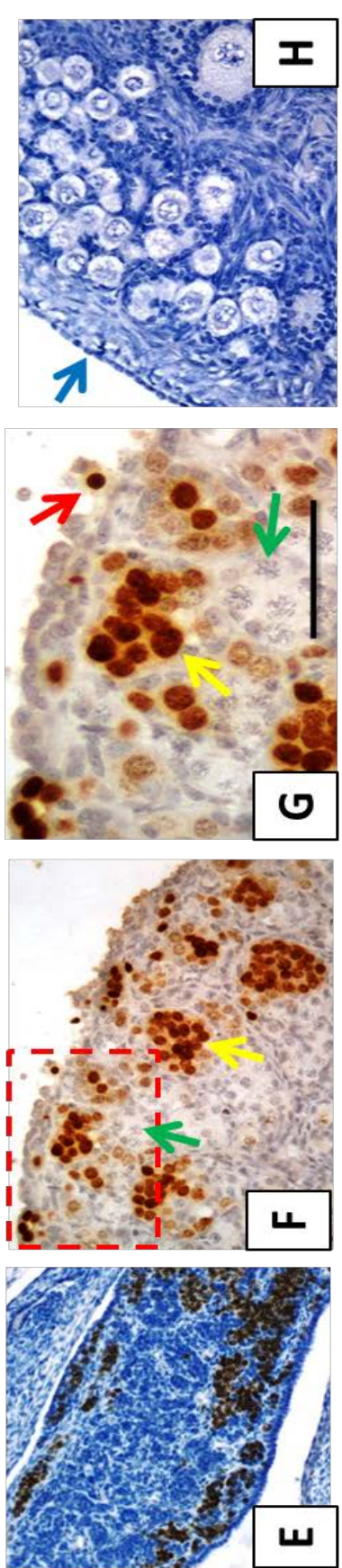

t77甘S
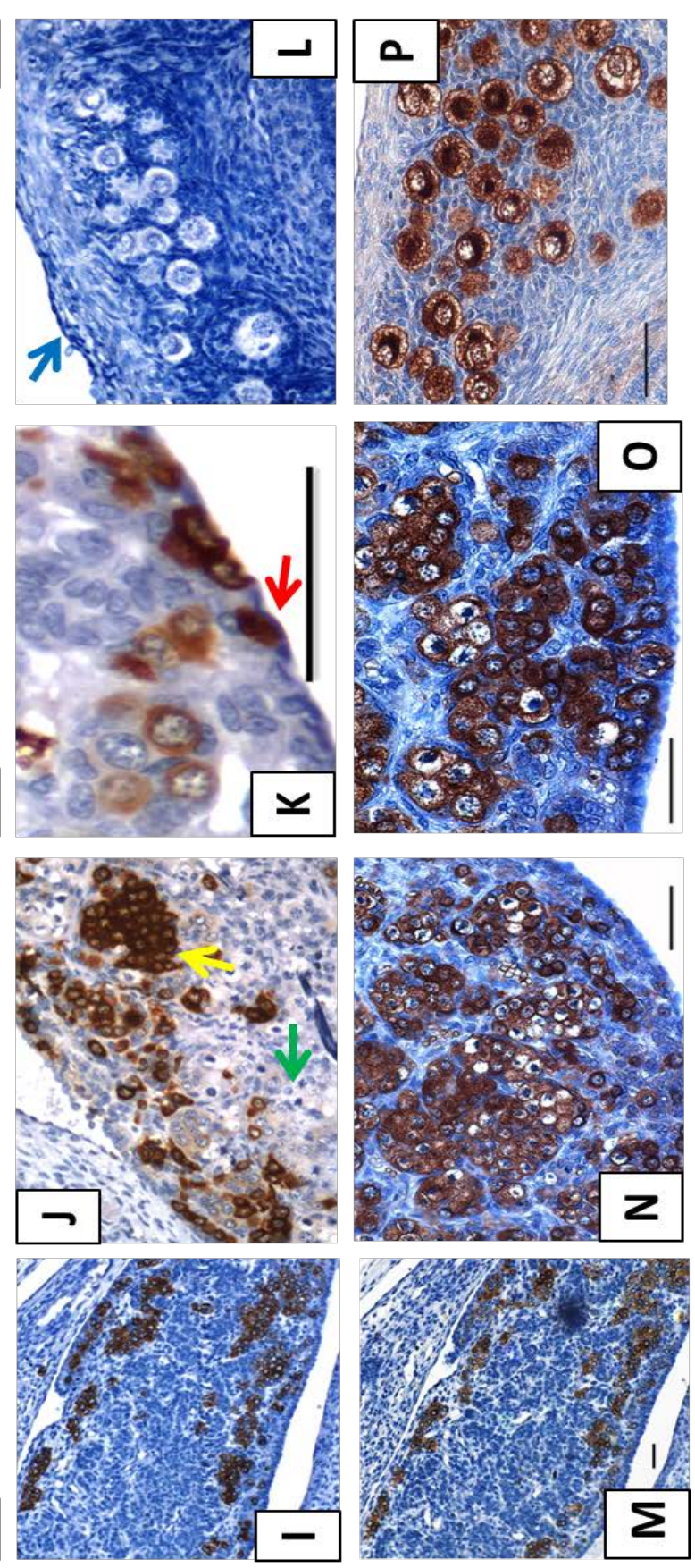

$8 Z N I 7$

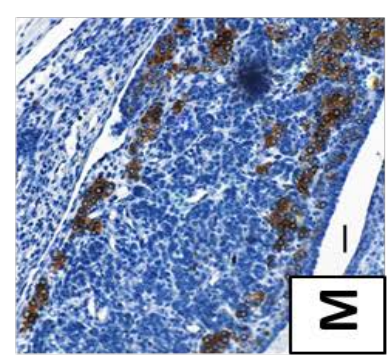

$\forall \mathbf{S} \forall \boldsymbol{\Lambda}$

Figure3 Immunohistochemical analyses of OCT4A, SALL4, LIN28, and VASA protein expression in fetal, neonatal and adolescent marmoset monkey ovary. OCT4A was detected in early fetal PGCs and oogonia (A). In the neonatal ovary OCT4A was present in premeiotic germ cells $(\mathbf{B}, \mathbf{C})$. Note the small structures strongly stained for OCT4A in $\mathbf{C}$ (red arrow). No OCT4A signal was seen in a one-year old ovary (D). (E) Shows strong SALL4 staining of germ cells in the fetal gonad. In the neonatal gonad premeiotic germ cells were strongly stained. There 
were also cells of the OSE stained (red arrow in $\mathbf{G}$ ) that had a significantly smaller nucleus than typical oogonia (F, G, yellow arrows). Meiotic cells exhibited only faint SALL4 signals. In older stages SALL4 was almost undetectable (H). (I) LIN28 was also specifically expressed in virtually all germ cells of the fetal gonad. In the neonatal gonad, LIN28 was found in oogonia and in some cells that were intermingled with or part of the OSE (J, K). No LIN28-positive cells were seen in the older ovary $(\mathbf{L})$. VASA as a general germ cell marker was present in all germ cell stages (M-P). The scale bars represent $50 \mu \mathrm{m}$. Where only one scale bar per column is present, it applies to all pictures in the respective column.

In order to further corroborate the germ cell identity of the pluripotency factor-positive cells we performed immunohistochemical double-stainings for OCT4A/VASA and LIN28/VASA (Fig.4). Cells expressing nuclear OCT4A had also VASA-positive cytoplasm (Fig.4A-C). In premeiotic cells there was also an almost complete overlap between LIN28 and VASA (Fig.5D-F). Only those cells with a nuclear morphology indicating entry into meiosis had low or no LIN28 expression, but were positive for VASA.
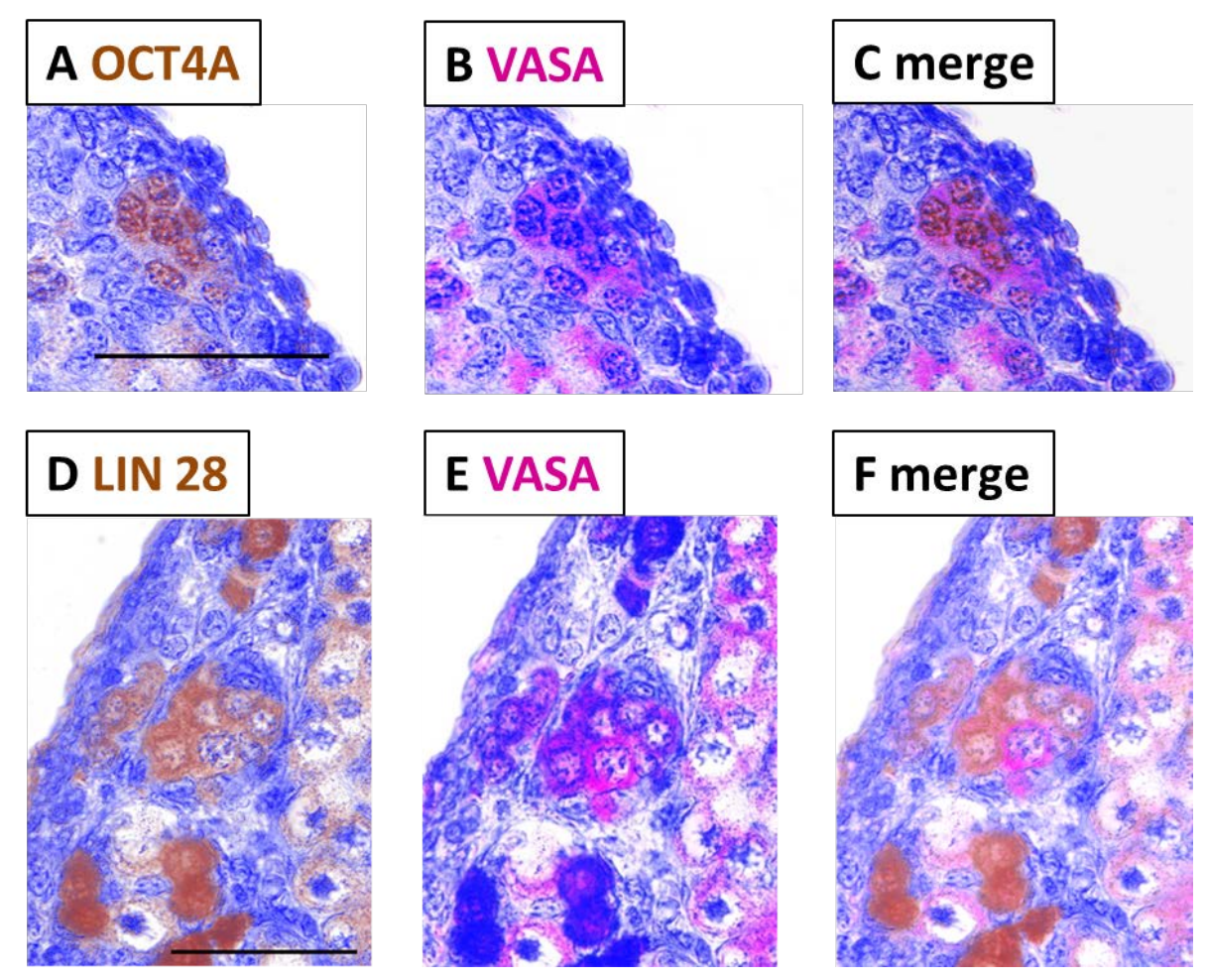

Figure4 Co-localization of pluripotency markers with the general germ cell marker VASA in neonatal marmoset ovary. (A) OCT4A-stained oogonia. The OCT4A signals are nuclear. 
(B) The same individual tissue section shown in A stained for VASA, which is predominantly cytoplasmic. (C) Merged stainings from A and B indicate that individual cells express both, OCT4A and VASA. (D) LIN28-stained oogonia. (E) The same tissue section shown in D stained for VASA. (F) Merged stainings from D and E. The scale bars represent $50 \mu \mathrm{m}$.

\section{Premeiotic germ cells express the proliferation marker Ki-67}

We were interested in whether the premeiotic germ cells in the neonatal ovary express the proliferation marker Ki-67. As positive control for highly proliferative marmoset cells we used marmoset monkey ES cells (Muller et al. 2009). Fig.5A shows intense nuclear signals for Ki-67 in marmoset monkey ES cells indicating cross-reactivity of the antibody with the marmoset Ki67 antigen. In contrast, proliferation arrested mouse feeder cells were not stained. Replacement

of the primary antibody with non-specific rabbit IgGs produced no signals (Fig.5B). When we stained neonatal marmoset ovaries for Ki-67, many germ cells in the outer cortical zone were positive (Fig.5C). This was also confirmed (data not shown) using a second independent Ki-67 antibody (Dako M7240; clone MB-1) which was used in previous studies with marmosets (McKinnell et al. 2013). Higher magnification (Fig.5D) revealed that the stained cells were predominantly premeiotic germ cells, while germ cells that entered meiosis were not stained. Only few putative somatic cells in the outer cortical zone were stained. Meiotic germ cells were Ki-67-negative. These data show that marmoset monkey neonatal ovaries contain a significant population of proliferating premeiotic germ cells. 

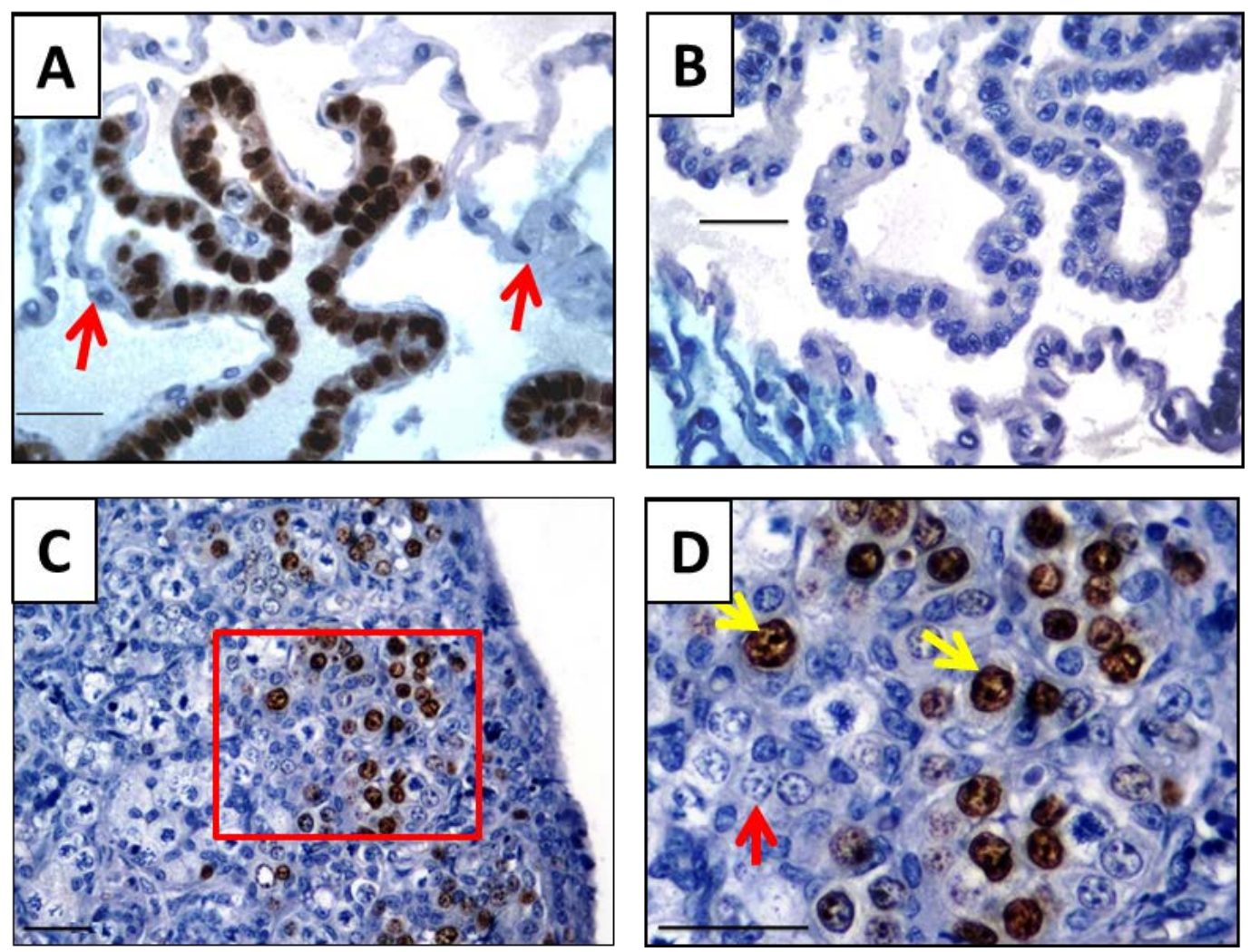

Figure 5 Expression analysis of the proliferation marker Ki-67 in the neonatal marmoset ovary. Marmoset ES cells as highly proliferative cells were used as positive control for the Ki-67 antibody (A, brown staining). Proliferation-arrested mouse embryonic feeder cells were not stained (red arrows). (B) Replacement of the primary antibody by the respective rabbit IgG produced no signals. (C) In neonatal marmoset ovaries the nuclei of the oogonia in the outer zone of the cortex were strongly and specifically labeled (D, yellow arrows). Neither the cytoplasm of oogonia nor oocytes (red arrow) were stained. The scale bars represent $50 \mu \mathrm{m}$.

\section{Co-localization of Ki-67 with pluripotency markers OCT4A and LIN28}

Finally, we were interested in whether individual cells express both, pluripotency markers and the proliferation marker Ki-67. Therefore, we tested the combinations OCT4A / Ki-67 and LIN28 / Ki-67 in double-stainings. Fig.6 A-C shows that the co-localization of OCT4A with Ki67 is almost complete in oogonia organized in cell nests. In contrast, individual oogonia still positive for Ki-67 exhibit only weak OCT4A signals (arrows in Fig.6A). Co-staining for LIN28 
and Ki-67 revealed that Ki67-positive cells were also LIN28-positive, even individual cells outside of cell nests (Fig.6D-F).
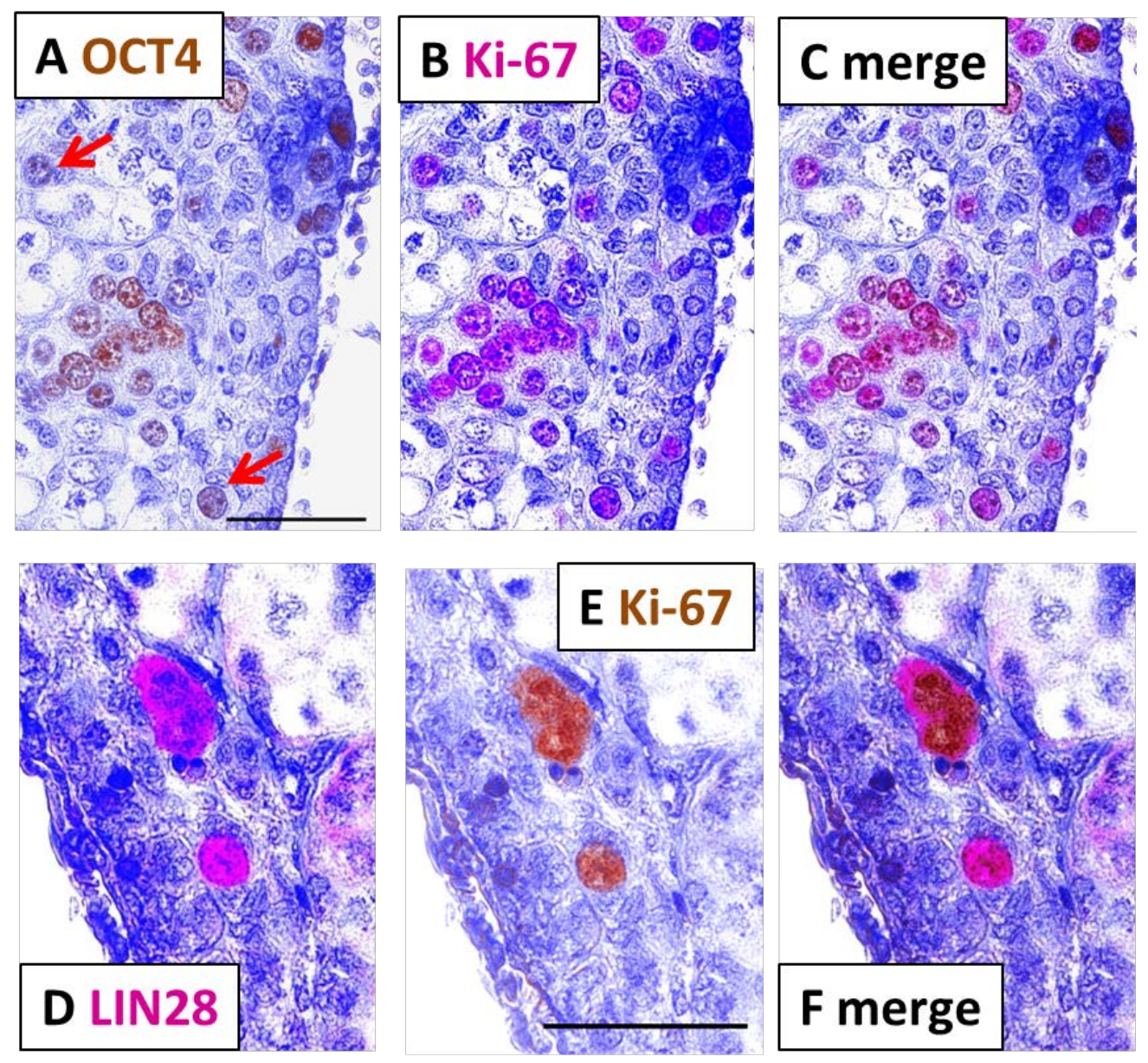

Figure 6 Co-localization of pluripotency markers with the proliferation marker Ki-67 in neonatal marmoset ovary. (A) OCT4A-stained oogonia. Oogonia with weak OCT4A signals are highlighted by a red arrow. (B) The same tissue section shown in A stained for Ki-67. (C) Merged stainings from A and B. (D) LIN28-stained oogonia. (E) The same tissue section shown in D stained for Ki-67. (F) Merged stainings from D and E. 


\section{Discussion}

We have demonstrated in the present study that the neonatal marmoset ovary exhibits a histologically undifferentiated zone underneath the OSE. We term this zone the indifferent cortical zone (ICZ). This zone has no counterpart in the neonatal human ovary (van Wagenen \& Simpson 1973, Sforza et al. 1993). In contrast to the human neonatal ovary, the marmoset ovary did not exhibit surface irregularities or deep organ lobulation (van Wagenen \& Simpson 1973). The neonatal marmoset monkey ovary also contains numerous premeiotic germ cells. This is in clear contrast to the human ovary, where the vast majority of oogonia enter meiosis early during embryonic / fetal development (Stoop et al. 2005, Hartshorne et al. 2009). In the postnatal human ovary there are at birth only very few premeiotic germ cells (Byskov et al. 2011). This striking difference between the human and the marmoset makes the marmoset very interesting with regard to at least two aspects: The first one is that "early” primate ovary development can be experimentally studied in postnatal animals. Hence, using the marmoset, it is possible to test the action of hormones or other bioactive substances on the progression of oogonia to meiosis and on folliculogenesis in vivo. This might be of special relevance in the area of reproductive toxicology. The second aspect is the relatively easy retrieval of proliferating primitive germ cells in order to try to establish germ line-derived pluripotent cell lines from the marmoset. Indeed, pluripotent cells were previously derived from human PGCs (Shamblott et al. 1998, Shamblott et al. 2001). PGCs express many pluripotency markers such as OCT4 (previous studies did not discriminated between OCT4 and OCT4A) or LIN28. As the postnatal marmoset oogonia appear to have a similar marker profile as PGCs, it is conceivable that the Ki-67-positive marmoset oogonia can be cultured and expanded under appropriate conditions. Besides ES cells and iPS cells such germ line-derived pluripotent cells might be an additional option to obtain pluripotent 
primate cells for comparative molecular studies on pluripotent cells of different origin and for testing the general suitability of germ line-derived pluripotent stem cells in regenerative medicine.

The developing human (Hartshorne et al. 2009, Byskov et al. 2011) and rhesus macaque (van Wagenen \& Simpson 1973) ovary have been studied in detail. Both are representatives of the old world primates (Catarrhini). Here we studied the developing marmoset monkey ovary as a representative of the new world primates (Platyrrhini) and found clear differences between these groups with regard to the presence of premeiotic germ cells in neonatal ovaries. Both, the new world and the old world primates belong to the simians (Anthropoidea). Despite the differences in the neonatal ovary, the Anthropoidea tested so far share the characteristic of absence of premeiotic germ cells in the adult ovary. Interestingly, in the primate group of prosimians (Strepsirhini) even in the adult ovary there are proliferating premeiotic germ cells present as very solid histological and isotope incorporation studies have shown already decades ago (Ioannou 1967, Butler \& Juma 1970). Unfortunately, the access to gonads of Strepsirhini is extremely limited or practically almost impossible today. However, it would be of major interest to extend the more detailed investigations on ovarian and germ cell development, which are possible with today's tools, to Strepsirhini. Availability of Strepsirhini would probably offer the opportunity to study female primate germ cell proliferation and folliculogenesis over the lifetime of the animal and not only during a short period of intrauterine or postnatal development. Furthermore, it should be taken into consideration that human ovarian development with very early loss of the premeiotic germ cell population may be an extreme peculiarity within the whole group of primates. 
The differentiation states of the somatic cell populations in the neonatal ovary were not the objective of the present study, which focused on premeiotic germ cells. However, the general histological immaturity of the neonatal marmoset gonad, especially the presence of the ICZ, suggests that also the somatic cells might be in a very primitive, supposedly fetal state as compared with human ovarian development. Although a detailed analysis is not provided in the present study, it is important to note that the ICZ of the neonatal marmoset monkey ovary is different from the primitive cortical tissue (PCT) that has been described for the human fetal and neonatal ovary (Sforza et al. 1993). Hence, the ICZ of the neonatal marmoset ovary has no direct histological counterpart in the neonatal human ovary (van Wagenen \& Simpson 1973, Forabosco et al. 1991, Sforza et al. 1993). The kind of description of the PCT by Sforza and colleagues (1993) strongly suggests that even the 20 week old human fetal ovary is more mature than the neonatal marmoset ovary.

Using an antibody against activated caspase 3, which is a specific marker of apoptotic cells, we were able to detect numerous positive cells in the neonatal thymus (positive control) and in a neonatal ovary which was cultured for 6 hours before fixation (supp. Fig.1). The freshly fixed neonatal ovary exhibited relatively few activated caspase 3-positive, i.e. apoptotic germ cells, as has been reported for the fetal human ovary (Fulton et al. 2005). However, due to the long period of time during which the oogonial population is present during development even the presence of only few apoptotic germ cells at a specific time point may have considerable consequences for the whole germ cell population over time (Fulton et al. 2005). This has to be studied in the marmoset ovary in more detail in the future. Nevertheless, the small structures strongly stained for OCT4A in Fig.3C may represent a degenerating nucleus of an apoptotic oogonium. 
In general, marmoset monkey embryos exhibit a developmental delay during the first half of gestation, which has been known for a long time (Phillips 1976, Merker et al. 1988). However, the (molecular) mechanisms inducing this developmental delay are not understood. Regarding the delayed gonad development, however, it is very likely, that the regular birth of co-twins, which are frequently of different sex, favors delayed gonadal development. In humans it is wellknown that already during fetal development phases of high sex steroid production occur (Scott et al. 2009). In case of twin fetuses of different sexes such a high fetal sex steroid production may interfere with the proper development of the other sex. This is a well-described phenomenon for instance in cattle, where infertile freematins are a rather common phenomenon (Padula 2005). Therefore it is plausible that endocrine-controlled phases of gonad development are postponed to postnatal periods in marmosets.

In conclusion, the neonatal marmoset monkey ovary is very immature compared to the neonatal human ovary. It contains a novel histological layer which we termed ICZ of the neonatal marmoset ovary. The ICZ has no counterpart in the developing human ovary. The neonatal marmoset ovary also contains numerous oogonia positive for pluripotency factors and the proliferation marker Ki-67, which is in clear contrast to the human neonatal ovary. Our findings may allow deeper investigations of the transition of primate oogonia to oocytes and of folliculogenesis in non-human primates in vivo. 


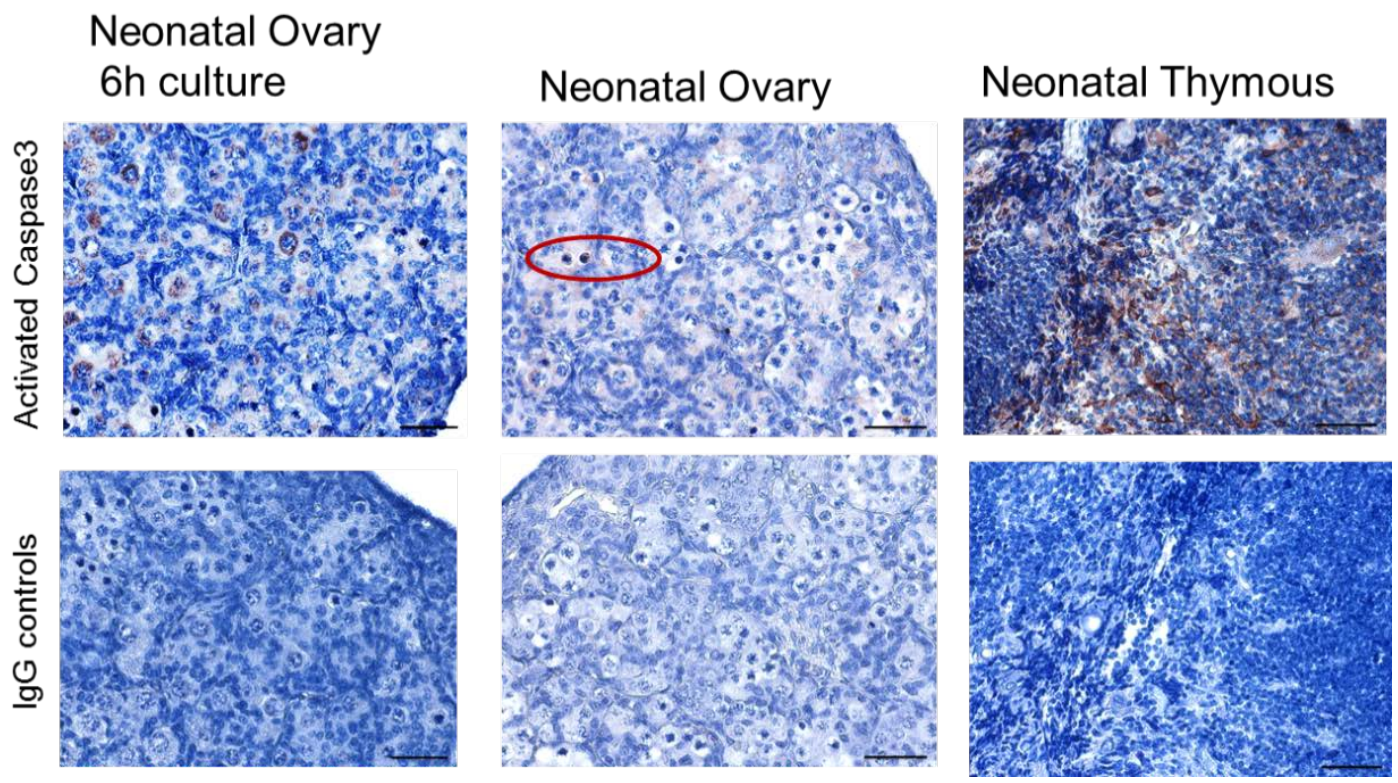

Supp. Fig. 1: Caspase 3 detection indicating apoptosis in neonatal marmoset monkey ovary. Using an antibody against activated Caspase 3, which is a specific marker of apoptotic cells, numerous positive cells were detected in the neonatal thymus (positive control, right panel) and in a neonatal ovary which was cultured for 6 hours before fixation (left panel). In contrast, the freshly fixed neonatal ovary exhibited only very few activated caspase 3-positive germ cells suggesting that apoptosis is not a major mechanism to regulate the germ cell population in the neonatal marmoset ovary.

Caspase 3 antibody (\#ab2302, Abcam) was used at a 1:50 dilution to detect activated Caspase 3. The staining procedure was similar to the described in the main text with the exception that the

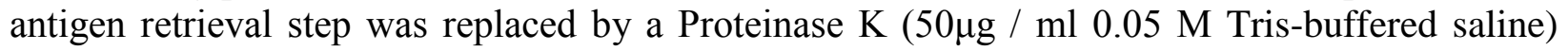
digestion of the sections for 15 minutes at room temperature.

IgG controls did not show any signals. 


\section{Declaration of interest}

The authors declare that there is no conflict of interest that could be perceived as prejudicing the impartiality of the research reported.

\section{Funding}

This work was supported mainly from institutional resources. This study was supported in parts also by a grant of the Deutsche Forschungsgemeinschaft (DFG; Be2296-6) entitled "Pluripotent cells from marmoset testis” to Rüdiger Behr, Stefan Schlatt and Jörg Gromoll.

\section{Acknowledgement}

We appreciate the excellent technical assistance of Nicole Umland, Angelina Berenson, and Simone Luert. We also thank Ellen Wiese for administrative support and the members of the animal facility for excellent animal husbandry. Bentolhoda Fereydouni is a PhD student at the Biological Faculty of the University of Göttingen on a scholarship of the Deutscher Akademischer Austauschdienst (DAAD). 


\section{References}

Aeckerle N, Dressel R \& Behr R 2013 Grafting of Neonatal Marmoset Monkey Testicular Single-Cell Suspensions into Immunodeficient Mice Leads to ex situ Testicular Cord Neomorphogenesis. Cells Tissues Organs 198 209-220.

Aeckerle N, Eildermann K, Drummer C, Ehmcke J, Schweyer S, Lerchl A, Bergmann M, Kliesch S, Gromoll J, Schlatt S \& Behr R 2012 The pluripotency factor LIN28 in monkey and human testes: a marker for spermatogonial stem cells? Mol Hum Reprod 18 477-488.

Albert S, Ehmcke J, Wistuba J, Eildermann K, Behr R, Schlatt S \& Gromoll J 2010 Germ cell dynamics in the testis of the postnatal common marmoset monkey (Callithrix jacchus). Reproduction $\mathbf{1 4 0}$ 733-742.

Anderson RA, Fulton N, Cowan G, Coutts S \& Saunders PT 2007 Conserved and divergent patterns of expression of DAZL, VASA and OCT4 in the germ cells of the human fetal ovary and testis. BMC Dev Biol 7136.

Beindorff N \& Einspanier A 2010 Luteotrophic effects of relaxin, chorionic gonadotrophin and FSH in common marmoset monkeys (Callithrix jacchus). Reproduction 139 923-930.

Bendsen E, Byskov AG, Andersen CY \& Westergaard LG 2006 Number of germ cells and somatic cells in human fetal ovaries during the first weeks after sex differentiation. Hum Reprod 21 30-35.

Butler H \& Juma MB 1970 Oogenesis in an adult prosimian. Nature 226 552-553.

Byskov AG, Hoyer PE, Yding Andersen C, Kristensen SG, Jespersen A \& Mollgard K 2011 No evidence for the presence of oogonia in the human ovary after their final clearance during the first two years of life. Hum Reprod 26 2129-2139.

Castrillon DH, Quade BJ, Wang TY, Quigley C \& Crum CP 2000 The human VASA gene is specifically expressed in the germ cell lineage. Proc Natl Acad Sci U S A 97 9585-9590.

Chambers PL \& Hearn JP 1979 Peripheral plasma levels of progesterone, oestradiol-17 beta, oestrone, testosterone, androstenedione and chorionic gonadotrophin during pregnancy in the marmoset monkey, Callithrix jacchus. J Reprod Fertil 56 23-32.

Chandolia RK, Luetjens CM, Wistuba J, Yeung CH, Nieschlag E \& Simoni M 2006 Changes in endocrine profile and reproductive organs during puberty in the male marmoset monkey (Callithrix jacchus). Reproduction 132 355-363.

Childs AJ, Kinnell HL, He J \& Anderson RA 2012 LIN28 is selectively expressed by primordial and premeiotic germ cells in the human fetal ovary. Stem Cells Dev 21 2343-2349.

Eildermann K, Aeckerle N, Debowski K, Godmann M, Christiansen H, Heistermann M, Schweyer S, Bergmann M, Kliesch S, Gromoll J, Ehmcke J, Schlatt S \& Behr R 2012 Developmental expression of the pluripotency factor sal-like protein 4 in the monkey, human and mouse testis: restriction to premeiotic germ cells. Cells Tissues Organs 196 206-220.

Elling U, Klasen C, Eisenberger T, Anlag K \& Treier M 2006 Murine inner cell mass-derived lineages depend on Sall4 function. Proc Natl Acad Sci U S A 103 16319-16324.

Finstermeier K, Zinner D, Brameier M, Meyer M, Kreuz E, Hofreiter M \& Roos C 2013 A mitogenomic phylogeny of living primates. PLoS One 8 e69504.

Forabosco A, Sforza C, De Pol A, Vizzotto L, Marzona L \& Ferrario VF 1991 Morphometric study of the human neonatal ovary. Anat Rec 231 201-208.

Fulton N, Martins da Silva SJ, Bayne RA \& Anderson RA 2005 Germ cell proliferation and apoptosis in the developing human ovary. J Clin Endocrinol Metab 90 4664-4670.

Hanazawa K, Mueller T, Becker T, Heistermann M, Behr R \& Sasaki E 2012 Minimally invasive transabdominal collection of preimplantation embryos from the common marmoset monkey (Callithrix jacchus). Theriogenology 78 811-816. 
Harlow CR, Gems S, Hodges JK \& J.P. H 1983 The relationship between plasma progesterone and the timing of ovulation and early embryonic development in the marmoset monkey. J Zool $201273-$ 282.

Hartshorne GM, Lyrakou S, Hamoda H, Oloto E \& Ghafari F 2009 Oogenesis and cell death in human prenatal ovaries: what are the criteria for oocyte selection? Mol Hum Reprod 15 805-819.

Hobbs RM, Fagoonee S, Papa A, Webster K, Altruda F, Nishinakamura R, Chai L \& Pandolfi PP 2012 Functional antagonism between Sall4 and Plzf defines germline progenitors. Cell Stem Cell 10 284-298.

Ioannou JM 1967 Oogenesis in adult prosimians. J Embryol Exp Morphol 17 139-145.

Kehler J, Tolkunova E, Koschorz B, Pesce M, Gentile L, Boiani M, Lomeli H, Nagy A, McLaughlin KJ, Scholer HR \& Tomilin A 2004 Oct4 is required for primordial germ cell survival. EMBO Rep $\mathbf{5}$ 1078-1083.

Kerr CL, Hill CM, Blumenthal PD \& Gearhart JD 2008 Expression of pluripotent stem cell markers in the human fetal ovary. Hum Reprod 23 589-599.

Li LH, Donald JM \& Golub MS 2005 Review on testicular development, structure, function, and regulation in common marmoset. Birth Defects Res B Dev Reprod Toxicol 74 450-469.

Liedtke S, Stephan M \& Kogler G 2008 Oct4 expression revisited: potential pitfalls for data misinterpretation in stem cell research. Biol Chem 389 845-850.

Lin ZY, Imamura M, Sano C, Nakajima R, Suzuki T, Yamadera R, Takehara Y, Okano HJ, Sasaki E \& Okano H 2012 Molecular signatures to define spermatogenic cells in common marmoset (Callithrix jacchus). Reproduction 143 597-609.

Liu Y, Wu C, Lyu Q, Yang D, Albertini DF, Keefe DL \& Liu L 2007 Germline stem cells and neo-oogenesis in the adult human ovary. Dev Biol 306 112-120.

Livak KJ \& Schmittgen TD 2001 Analysis of relative gene expression data using real-time quantitative PCR and the 2(-Delta Delta C(T)) Method. Methods 25 402-408.

Luetjens CM, Stukenborg JB, Nieschlag E, Simoni M \& Wistuba J 2008 Complete spermatogenesis in orthotopic but not in ectopic transplants of autologously grafted marmoset testicular tissue. Endocrinology 149 1736-1747.

Maheshwari A \& Fowler PA 2008 Primordial follicular assembly in humans--revisited. Zygote 16 285296.

Mamsen LS, Brochner CB, Byskov AG \& Mollgard K 2012 The migration and loss of human primordial germ stem cells from the hind gut epithelium towards the gonadal ridge. Int J Dev Biol 56 771778.

Mansfield K 2003 Marmoset models commonly used in biomedical research. Comp Med 53 383-392.

McKinnell C, Mitchell RT, Morris K, Anderson RA, Kelnar CJ, Wallace WH \& Sharpe RM 2013 Perinatal germ cell development and differentiation in the male marmoset (Callithrix jacchus): similarities with the human and differences from the rat. Hum Reprod 28 886-896.

McKinnell C, Mitchell RT, Walker M, Morris K, Kelnar CJ, Wallace WH \& Sharpe RM 2009 Effect of fetal or neonatal exposure to monobutyl phthalate (MBP) on testicular development and function in the marmoset. Hum Reprod 24 2244-2254.

Merker HJ, Sames K, Csato W, Heger W \& Neubert D 1988. The Embryology of Callithrix jacchus. In Nonhuman primate: developmental biology and toxicology, pp. 217-242.

Mitchell RT, Cowan G, Morris KD, Anderson RA, Fraser HM, McKenzie KJ, Wallace WH, Kelnar CJ, Saunders PT \& Sharpe RM 2008 Germ cell differentiation in the marmoset (Callithrix jacchus) during fetal and neonatal life closely parallels that in the human. Hum Reprod 23 2755-2765.

Muller T, Fleischmann G, Eildermann K, Matz-Rensing K, Horn PA, Sasaki E \& Behr R 2009 A novel embryonic stem cell line derived from the common marmoset monkey (Callithrix jacchus) exhibiting germ cell-like characteristics. Hum Reprod 24 1359-1372. 
Padula AM 2005 The freemartin syndrome: an update. Anim Reprod Sci 87 93-109.

Parte S, Bhartiya D, Manjramkar DD, Chauhan A \& Joshi A 2013 Stimulation of ovarian stem cells by follicle stimulating hormone and basic fibroblast growth factor during cortical tissue culture. $J$ Ovarian Res 620.

Perelman P, Johnson WE, Roos C, Seuanez HN, Horvath JE, Moreira MA, Kessing B, Pontius J, Roelke M, Rumpler Y, Schneider MP, Silva A, O'Brien SJ \& Pecon-Slattery J 2011 A molecular phylogeny of living primates. PLoS Genet 7 e1001342.

Perrett RM, Turnpenny L, Eckert JJ, O'Shea M, Sonne SB, Cameron IT, Wilson DI, Rajpert-De Meyts E \& Hanley NA 2008 The early human germ cell lineage does not express SOX2 during in vivo development or upon in vitro culture. Biol Reprod 78 852-858.

Phillips IR 1976 The Embryology of the Common Marmoset (Callithrix jacchus). Advances in Anatomy, Embryology and Cell Biology: Springer Verlag.

Sasaki E, Hanazawa K, Kurita R, Akatsuka A, Yoshizaki T, Ishii H, Tanioka Y, Ohnishi Y, Suemizu H, Sugawara A, Tamaoki N, Izawa K, Nakazaki Y, Hamada H, Suemori H, Asano S, Nakatsuji N, Okano H \& Tani K 2005 Establishment of novel embryonic stem cell lines derived from the common marmoset (Callithrix jacchus). Stem Cells 23 1304-1313.

Sasaki E, Suemizu H, Shimada A, Hanazawa K, Oiwa R, Kamioka M, Tomioka I, Sotomaru Y, Hirakawa R, Eto T, Shiozawa S, Maeda T, Ito M, Ito R, Kito C, Yagihashi C, Kawai K, Miyoshi H, Tanioka Y, Tamaoki N, Habu S, Okano H \& Nomura T 2009 Generation of transgenic non-human primates with germline transmission. Nature 459 523-527.

Scholer HR, Ruppert S, Suzuki N, Chowdhury K \& Gruss P 1990 New type of POU domain in germ linespecific protein Oct-4. Nature 344 435-439.

Scholzen T \& Gerdes J 2000 The Ki-67 protein: from the known and the unknown. J Cell Physiol 182 311322.

Scott HM, Mason JI \& Sharpe RM 2009 Steroidogenesis in the fetal testis and its susceptibility to disruption by exogenous compounds. Endocr Rev 30 883-925.

Sforza C, Ferrario VF, De Pol A, Marzona L, Forni M \& Forabosco A 1993 Morphometric study of the human ovary during compartmentalization. Anat Rec 236 626-634.

Shamblott MJ, Axelman J, Littlefield JW, Blumenthal PD, Huggins GR, Cui Y, Cheng L \& Gearhart JD 2001 Human embryonic germ cell derivatives express a broad range of developmentally distinct markers and proliferate extensively in vitro. Proc Natl Acad Sci U S A 98 113-118.

Shamblott MJ, Axelman J, Wang S, Bugg EM, Littlefield JW, Donovan PJ, Blumenthal PD, Huggins GR \& Gearhart JD 1998 Derivation of pluripotent stem cells from cultured human primordial germ cells. Proc Natl Acad Sci U S A 95 13726-13731.

Stoop H, Honecker F, Cools M, de Krijger R, Bokemeyer C \& Looijenga LH 2005 Differentiation and development of human female germ cells during prenatal gonadogenesis: an immunohistochemical study. Hum Reprod 20 1466-1476.

Tomioka I, Takahashi T, Shimada A, Yoshioka K \& Sasaki E 2012 Birth of common marmoset (Callithrix jacchus) offspring derived from in vitro-matured oocytes in chemically defined medium. Theriogenology 78 1487-1493.

van Wagenen G \& Simpson ME 1973 Postnatal development of the ovary in Homo sapiens and Macaca mulatta and Induction of Ovulation in the Macaque. New Haven and London: Yale University Press.

von Schonfeldt V, Chandolia R, Kiesel L, Nieschlag E, Schlatt S \& Sonntag B 2011 Advanced follicle development in xenografted prepubertal ovarian tissue: the common marmoset as a nonhuman primate model for ovarian tissue transplantation. Fertil Steril 95 1428-1434.

Wang X \& Dai J 2010 Concise review: isoforms of OCT4 contribute to the confusing diversity in stem cell biology. Stem Cells 28 885-893. 
West JA, Viswanathan SR, Yabuuchi A, Cunniff K, Takeuchi A, Park IH, Sero JE, Zhu H, Perez-Atayde A, Frazier AL, Surani MA \& Daley GQ 2009 A role for Lin28 in primordial germ-cell development and germ-cell malignancy. Nature 460 909-913.

Yuan J, Zhang D, Wang L, Liu M, Mao J, Yin Y, Ye X, Liu N, Han J, Gao Y, Cheng T, Keefe DL \& Liu L 2013 No evidence for neo-oogenesis may link to ovarian senescence in adult monkey. Stem Cells $\mathbf{3 1}$ 2538-2550. 
Running title: Oocyte-like cell development in monkeys

\title{
Long-term oocyte-like cell development in cultures derived from neonatal marmoset monkey ovary
}

\author{
Bentolhoda Fereydouni ${ }^{1}$, Gabriela Salinas-Riester ${ }^{2}$, Michael Heistermann ${ }^{3}$, Ralf Dressel ${ }^{4}$, Lucia \\ Lewerich $^{1}$, Charis Drummer ${ }^{1}$, Rüdiger Behr ${ }^{1}$ \\ ${ }^{1}$ Stem Cell Biology Unit, German Primate Center - Leibniz Institute for Primate Research, \\ Kellnerweg 4, 37077 Göttingen, Germany \\ ${ }^{2}$ Microarray and Deep-Sequencing Core Facility, University Medical Center Göttingen (UMG), \\ Justus-von-Liebig-Weg 11, 37077 Göttingen \\ ${ }^{3}$ Endocrinology Laboratory, German Primate Center - Leibniz Institute for Primate Research, \\ Kellnerweg 4, 37077 Göttingen, Germany \\ ${ }^{4}$ Department of Cellular and Molecular Immunology, University of Göttingen, Humboldtallee \\ 34, 37073 Göttingen, Germany
}

\section{Author contribution:}

Bentolhoda Fereydouni:

Conception and design, Collection and assembly of data, Data analysis and interpretation, Manuscript writing, Final approval of manuscript

Gabriela Salinas-Riester:

Collection and assembly of data, Data analysis and interpretation, Manuscript writing, Final approval of manuscript

Michael Heistermann:

Collection and assembly of data, Data analysis and interpretation, Final approval of manuscript

Ralf Dressel: Financial support, Collection and/or assembly of data, Final approval of manuscript 
Lucia Lewerich:

Collection and/or assembly of data, Data analysis and interpretation, Final approval of manuscript

Charis Drummer:

Provision of study material, Final approval of manuscript

Rüdiger Behr:

Conception and design, Financial support, Collection and/or assembly of data, Data analysis and interpretation, Manuscript writing, Final approval of manuscript

\section{Corresponding author's address:}

Rüdiger Behr

German Primate Center

Stem Cell Biology Unit

Kellnerweg 4

D-37077 Göttingen

Germany

Fon: +49 551-3851-132

Fax: +49 551-3851- 431

Email: rbehr@dpz.eu

\section{Declaration of interest}

The authors declare that there is no conflict of interest that could be perceived as prejudicing the impartiality of the research reported.

\section{Funding}

Bentolhoda Fereydouni is on a scholarship of the Deutscher Akademischer Austauschdienst (DAAD). The work was mainly supported by institutional resources and marginally by a grant of the Deutsche Forschungsgemeinschaft (DFG; Be2296-6) entitled "Pluripotent cells from marmoset testis” to Rüdiger Behr. 
Key words: ovary, oogonia, germ cell, germ line stem cell, VASA, non-human primate

\begin{abstract}
The existence and putative physiological relevance of female germ line stem cells (FGSCs; synonymously oogonial stem cells; OSCs) in mammalian ovaries is discussed intensively. Studies in different species provided contradictory data. We use the common marmoset monkey (Callithrix jacchus) as a preclinical non-human primate model to study reproductive and stem cell biology. The neonatal marmoset monkey ovary contains numerous primitive premeiotic germ cells (oogonia) expressing pluripotent stem cell markers and the germ cell marker DDX4 (VASA). Noteworthy, the presence of oogonia in the neonatal marmoset ovary is a peculiarity compared to neonatal human and rodent. Here, we aimed at culturing marmoset FGSCs from neonatal ovaries. We established cultures for more than 20 passages and 5 months. Importantly, comparative transcriptome analysis of the first passages with reference samples including native neonatal ovary and ES cells revealed a lack of germ cell and pluripotency genes indicating the immediate loss of the germ cells in culture. From passage 4 onwards, however, the cultures produced under specific conditions oocyte-like cells (OLCs). OLCs were free-floating, $\sim 40 \mu \mathrm{m}$ in diameter and strongly expressed several germ cell markers. The cultured ovarian cell did not developed teratoma- or ovarian-like tissues after transplantation into immunodeficient mice. In summary, our novel primate ovarian cell culture initially lacked germ cells, but then recovered germ cell marker expression and produced OLCs. This suggests the presence of FGSCs in the cultures. However, their identity and functional characteristics need to be determined, but we hypothesize that FGSCs lack the typical germ cell signature.
\end{abstract}




\section{Introduction}

It is a long-held opinion in reproductive biology that in females of most species, including the human, the postnatal germ cell pool is limited in number and cannot be replenished or even expanded. Early studies in the rat showed that oogonia, the proliferating female germ line progenitor cells that enter meiosis to produce oocytes, were found only during fetal development ${ }^{1}$. Human females are also thought to be born with a non-renewable pool of germ cell follicles which declines with age ${ }^{2}$. In postnatal human ovaries, oogonia were found only very sporadically and were undetectable by the age of two years ${ }^{3}$. A lack of evidence for postnatal germ cell proliferation in human ovaries was also reported by Liu, Wu, Lyu, Yang, Albertini, Keefe, Liu ${ }^{4}$. Instead, by far most of the proliferation-competent oogonia in the human ovary enter meiosis by the end of the second trimester of gestation ${ }^{5,6}$. Recent studies using transgenic mice and non-human primates reported also evidence for no proliferation of germ cells in adult mouse ${ }^{7,8}$ and monkey ${ }^{9}$ ovaries. However, these data supporting the view of a fixed postnatal female germ cell pool are profoundly challenged by reports starting a decade ago ${ }^{10,11}$, suggesting replenishment of the ovarian germ cell pool in mice. The existence of mitotically active germ line stem cells in postnatal mouse and human ovaries was supported by the isolation, molecular characterization, and transplantation of cell populations e.g.; ${ }^{12,}{ }^{13}, 14$. Probably the strongest evidence so far for a germ line stem cell pool in the ovary was provided by ${ }^{12}$, who generated mouse female germ line stem cells (FGSCs) with the ability to reconstitute oogenesis and produce offspring after transplantation. Other authors ${ }^{15}$, for review see ${ }^{16,17}$ reported the production of oocyte-like cells in vitro from cultures of adult ovarian surface epithelium (OSE). In summary, currently there are several apparently highly contradictory reports which provide 
data supporting or negating generation of new oocytes in the postnatal rodent and primate including the human - ovary.

We use the common marmoset monkey (Callithrix jacchus) as a non-human primate model to study reproductive and stem cell biology. We have recently shown that there are numerous oogonia present in the neonatal marmoset monkey ovary, but failed to detect these pluripotency marker (OCT4A, LIN28 and SALL4), proliferation marker (KI-67), and germ cell marker (VASA) -positive cell population in the one-year-old and adult ovary ${ }^{18}$ indicating a fast postnatal oogonial clearing also in this non-human primate species. Here, we report studies on the culture of neonatal marmoset ovarian cells. We tested a mouse embryonic fibroblast (MEF)based cell culture system combined with either a fetal bovine serum (FBS)-enriched medium supporting the culture of most mammalian cell lines (DMEM/F12; termed condition 1) or a medium specifically supporting marmoset monkey pluripotent stem cells lacking FBS (ESM, condition 2). Both conditions allowed a long-term culture of ovarian cells, but germ cell marker expression was globally lost under both conditions already in the first passage. However, specifically under condition 1 we observed in later passages the development of oocyte-like cells with a diameter $\sim 40 \mu \mathrm{m}$ and strongly expressing several germ cell markers. This study demonstrates for the first time the development of non-human primate oocyte-like cells from long-term ovarian cell cultures. 


\section{Animals and methods}

\section{Animals}

Common marmoset monkeys (Callithrix jacchus) were studied. Monkeys were housed in the self-sustaining colony of the German Primate Center (Deutsches Primatenzentrum; DPZ) according to standard housing for marmoset monkeys. The legal guidelines for the use of animals and the institutional guidelines of the DPZ for the care and use of marmoset monkeys were strictly followed. According to applicable law no separate or specific license is necessary to harvest organs after euthanizing the animals. The marmosets were housed as breeding pairs. In captivity, they often give birth to triplets or even quadruplets. However, the mother is usually able to feed and rear only two neonates, which is the normal litter size of free-living marmosets. Therefore, the female neonates (age 1-5 days) from triplet or quadruplet births were used to collect organs for this study. Neonatal marmosets were selected based on the changes in body weight of the neonates. The ones that had lowest birth weight or the one that lost most weight during the first 1-5 postnatal days due to the inability of the mother to nourish three offspring were selected for euthanasia. All animals were narcotized with Pentobarbital (Narcoren ${ }^{\circledR} ; 0,05$ $\mathrm{ml}$ intramuscular) and euthanized with an intracardial injection of 0,5 ml Pentobarbital before a lack of nourishment caused evident suffering of the animals. The marmosets were housed in a temperature- $\left(25 \pm 1^{\circ} \mathrm{C}\right)$ and humidity-controlled (65 $\left.\pm 5 \%\right)$ facility. The light:dark cycle was 12:12 hours. The animals were fed ad libitum with a pelleted marmoset diet. In addition, $20 \mathrm{~g}$ mash per animal was served in the morning and $30 \mathrm{~g}$ fruits or vegetables mixed with noodles or rice were supplied in the afternoon. Drinking water was also available ad libitum. 


\section{Numbers of animals}

Altogether, ovaries from 9 neonatal marmosets were used in this study: 5 pairs for culture under condition 1, 3 pairs for culture under condition 2 and one pair as reference for transcripome analysis.

\section{Neonatal common marmoset monkey ovarian cell cultures}

Neonatal ovaries were first collected in a petri dish containing cold DPBS. Fat and blood cells were removed and the whole ovary including the OSE was minced with sterile scissors. Minced ovaries were then transferred to $15 \mathrm{ml}$ falcon tube. After gentle centrifugation, DPBS was removed and ovarian tissue fragments were re-suspended in DMEM/F12 medium containing collagenase (Sigma\#C2674) and DNase and kept for 45 minutes at $37^{\circ} \mathrm{C}$. Every 5 to 10 min the ovaries were gently pipetted to destruct the tissue. Finally, 10\% FBS was added to inactivate the enzyme. Cells were passed through $70 \mu \mathrm{m}$ strainer (BD, USA) and were centrifuged at $200 \mathrm{~g}$ for 10 min. Then the supernatant was removed and the cells were re-suspended in culture medium and transferred on mouse embryonic fibroblast (MEF) feeder at a concentration $3-5 \times 10^{5}$ cells per $5 \mathrm{~cm}$ well. After one week large colonies were individually picked with a micro probe (FST, Heidelberg, Germany, \# 10032-13) and digested with Accutase for 4 min. Then the cells were centrifuged at $300 \mathrm{~g}$ for 10 minutes and re-suspended in the culture medium for further passages. Cultures were maintained at $37^{\circ} \mathrm{C}$ under $5 \% \mathrm{CO}_{2}$ and $5 \%$ oxygen in a humidified incubator.

\section{Culturing neonatal common marmoset ovaries}

Two different cell culture conditions, both based on mouse embryonic fibroblast (MEF) feeder culture, were tested. Condition 1 was: DMEM/F12 supplemented with FBS (10\%), Pen/Strep, AmpB and human LIF $(10 \mu \mathrm{g} / \mathrm{ml})$. Condition 2 was ES cell medium consisting of KO-DMEM, 
20 \% Knockout Serum Replacement, 1 mM MEM-non-essential amino acids (NEAA), 2 mM GlutaMAX, $50 \mu \mathrm{M}$ ß-ME, and 1\% Pen/Strep. For further passages (usually after 7-10 days) colonies were mechanically removed with a sterile probe, digested with accutase and placed on a newly prepared MEF layer.

\section{Immunofluorescence staining}

For immunofluorescence staining, medium was removed and cell colonies were washed twice in PBS and then fixed in 4\% PFA for 15 minutes. Cells were permeabilized by $0.1 \%$ Triton X-100 in PBS for 10 minutes at room temperature. Primary antibodies were diluted in 3\% BSA-PBS, and colonies were incubated for $1 \mathrm{~h}$ at $37^{\circ} \mathrm{C}$. Cells were washed twice in PBS. The secondary antibody, which was diluted in 3\% BSA-PBS, was added to the cells and incubated for 20 minutes in a dark box at $37{ }^{\circ} \mathrm{C}$. Cells were washed again twice in PBS and 5\% DAPI-PBS was added. Cells were washed again with PBS and mounted with Citiflur (Science services AF1 Glycerol / PBS solution). For negative controls, the primary antibody was (i) omitted or (ii) replaced by IgG isotopes.

\section{Histology and immunohistochemistry staining}

Histology of the colonies was performed after mechanically detaching of whole MEF layer including the ovarian cell colonies from the cell culture well. After detachment, the randomly arranged MEF layer was fixed in Bouin's solution for 3 hours, washed several times for at least $24 \mathrm{~h}$ in $70 \% \mathrm{EtOH}$ and then embedded in paraffin wax. The resulting cell culture conglomerate was randomly sectioned. Due to the large number of colonies amply different sections of ovarian cell colonies in different orientations were available for histological analysis. 
Immunhistochemistry was performed as described recently ${ }^{18}$. The VASA antibody (\#AF2030, R\&D systems) was used in a 1:100 solution.

\section{Western blot analysis}

Western blotting was performed according to standard procedures. In brief, $20 \mathrm{mg}$ of frozen tissue per sample were used. Proteins were isolated by mechanical destruction of the tissue in a tissuelyser at $50 \mathrm{HZ}$ (Qiagen, Hilden, Germany). The samples were denatured for 5 minutes at $95^{\circ} \mathrm{C}$. Samples were then run on a $10 \%$ SDS-page gel in Tris $\mathrm{HCl}$ buffer, $\mathrm{pH}$ 8.8, and then semidry blotted onto a PVDF membrane (150 mA for 1h). Blocking of unspecific binding was achieved by incubating the membrane in 5\% skim milk powder diluted in TBS for $1 \mathrm{~h}$. Primary antibodies against VASA (R\&D Systems, AF2030) and $\beta$-ACTIN (Santa Cruz, SC-1616-R) were diluted in blocking buffer. Membranes were incubated in primary antibody solutions for 16 hours at $4^{\circ} \mathrm{C}$ and then washed three times with blocking solution supplemented with tween 20 . After incubation with the horseradish peroxidase-coupled secondary antibody $\left(1 \mathrm{~h}\right.$ at $\left.20^{\circ} \mathrm{C}\right)$ the membrane was washed again. Detection of bound antibody was performed using the Amersham ECL Western Blotting Detection Reagents kit (RPN2106). Signals were detected and documented using the ChemoCam Imager (INTAS, Göttingen, Germany).

\section{Transcriptome Analysis}

For transcriptome analysis, two neonatal marmoset ovaries, colonies from P1, P3 and P4 from two different individual animals per condition, marmoset fibroblasts and marmoset ES cells were analyzed. RNA was isolated using the TRIzol ${ }^{\circledR}$ Reagent (Life Technologies) according to manufacturer instructions. RNA quality was assessed by measuring the RIN (RNA Integrity 
Number) using an Agilent 2100 Bioanalyzer (Agilent Technologies, Palo Alto, CA). Library preparation for RNA-Seq was performed using the TruSeq RNA Sample Preparation Kit (Illumina, Cat. $\left.\mathrm{N}^{\circ} \mathrm{RS}-122-2002\right)$ starting from $500 \mathrm{ng}$ of total RNA. Accurate quantitation of cDNA libraries was performed by using the QuantiFluor ${ }^{\mathrm{TM}}$ dsDNA System (Promega). The size range of final cDNA libraries was determined applying the DNA 1000 chip on the Bioanalyzer 2100 from Agilent (280 bp). cDNA libraries were amplified and sequenced by using the cBot and HiSeq2000 from Illumina (SR; 1x50 bp;56 GB ca. 30-35 million reads per sample). Sequence images were transformed with Illumina software BaseCaller to bcl files, which were demultiplexed to fastq files with CASAVA v1.8.2. Quality check was done via fastqc (v. 0.10.0, Babraham Bioinformatics). The alignment was performed using Bowtie2 v2.1.0 to the cDNA for Callithrix jacchus. Data were converted and sorted by samtools 0.1.19 and reads per gene were counted via htseq version 0.5.4.p3. Data analysis was performed using R/Bioconductor (3.0.2/2.12) loading DESeq, gplots and goseq packages. Candidate genes were filtered to a minimum of $4 \mathrm{x}$ fold change and FDR-corrected $\mathrm{p}$-value $<0.05$. The data discussed in this paper were generated in compliance with the MIAME guidelines and have been deposited in NCBI's Gene Expression Omnibus and are accessible through GEO Series accession number XXXXX (will be completed upon acceptance of the MS).

\section{Quantitative Reverse Transcriptase Polymerase Chain Reaction (RT-qPCR) analysis}

RT-qPCR was carried out as described previously ${ }^{18}$. Total RNA was extracted from different passages of colony-forming cells from both conditions. For condition one, colonies from passages P1 to P5, P9, P11, and P13 were used. As positive controls, neonatal marmoset ovary and marmoset embryonic stem cells were used. Marmoset monkey fibroblasts were used as a biological negative control for pluripotency and germ cell markers. For condition two, colonies 
from passages P1 to P7 were analyzed. Primers are listed in Supp. Table 1. For oocyte- like cell RNA extractions, 28 cells from different passages were collected. Their RNA was isolated with the RNeasy MICRO kit (Qiagen) according to manufacturer's instructions.

\section{Hormone measurements}

Measurement of progesterone in the selected cell culture medium samples after at least 3 days of conditioning was performed using an enzymeimmunoassay (EIA) using antiserum raised in sheep against progesterone-11-hemisuccinate-BSA as described by Heistermann and colleagues

${ }^{19}$. Fresh medium was used as control. Estradiol-17ß was determined using an EIA according to ${ }^{20}$ with the exception that 17ß-estradiol-6-horse-radish-peroxidase was used as label. Both steroid measurements were performed in undiluted samples and fresh medium was used as control.

\section{Cell transplantation assay}

We injected $\sim 10^{6}$ cells per mouse from the $5^{\text {th }}$ passage subcutaneously into 4 female adult RAG2 $^{-/} \gamma \mathrm{c}^{-/-}$mice lacking B, T, and NK cells. The procedure has been described previously ${ }^{21}$. 
Table 1: Primer sequences, sizes of PCR products and concentrations of primers.

\begin{tabular}{|l|l|c|c|}
\hline \multicolumn{1}{|c|}{ Primer } & \multicolumn{1}{|c|}{ Primer sequence } & $\begin{array}{c}\text { PCR } \\
\text { product } \\
\text { size (bp) }\end{array}$ & $\begin{array}{c}\text { Concentration } \\
\text { [nM] }\end{array}$ \\
\hline Cj_GAPDH_Fw & 5'-TGCTGGCGCTGAGTATGTG-3' & 64 & 300 \\
\hline Cj_GAPDH_Re & 5'-AGCCCCAGCCTTCTCCAT-3' & 50 \\
\hline Cj_LIN28_Fw & 5'-GACGTCTTTGTGCACCAGAGTAA-3' & 67 & 300 \\
\hline Cj_LIN28_Re & 5'-CGGCCTCACCTTCCTTCAA-3' & & 50 \\
\hline Cj_SALL4_Fw & 5'-AAGGCAACTTGAAGGTTCACTACA- & 77 & 900 \\
\hline Cj_SALL4_Re & 5'-GATGGCCAGCTTCCTTCCA-3' & & 50 \\
\hline Cj_VASA_Fw & 5'-TGGACATGATGCACCACCAGCA-3' & 210 & 50 \\
\hline Cj_VASA_Re & 5'-TGGGCCAAAATTGGCAGGAGAAA-3' & & 500 \\
\hline Cj_OCT4A_Fw & 5'-GGAACAAAACACGGAGGAGTC-3' & 234 & 300 \\
\hline Cj_OCT4A_Re & 5'-CAGGGTGATCCTCTTCTGCTTC-3' & & 50 \\
\hline Cj_PRDM1_fw & 5'-ATGAAGTTGCCTCCCAGCAA-3' & 147 & 50 \\
\hline Cj_PRDM1_Re & 5'- TTCCTACAGGCACCCTGACT-3' & & 50 \\
\hline Cj_PRDM14_fw & 5'-CGGGGAGAAGCCCTTCAAAT -3' & 91 & 50 \\
\hline Cj_PRDM14_Re & 5'-CTCCTTGTGTGAACGTCGGA -3' & & 50 \\
\hline Cj_DAZL_Fw & 5'-GAAGAAGTCGGGCAGTGCTT -3' & 70 & 50 \\
\hline Cj_DAZL_Re & 5'- AACGAGCAACTTCCCATGAA-3' & & 50 \\
\hline Cj_DPPA3_Fw & 5'-GCGGATGGGATCCTTCTGAG -3' & 129 & 50 \\
\hline Cj_NOBOX_Re & 5'- TCAGAAGTCAGCAGCATGGGG-3' & & 50 \\
\hline
\end{tabular}




\section{Results}

\section{General observations and morphology of the primary cell cultures}

We studied neonatal monkey ovarian cell cultures on mouse embryonic fibroblasts (MEFs) under two different conditions: Condition 1 [C1] was DMEM-based supplemented by 10\% FBS and condition 2 [C2] was serum-free embryonic stem cell medium. Under both conditions we successfully established a long-term primary culture of ovarian cells. This included passaging as well as expansion of the cells. Under C1, 5 different individual primary cultures of neonatal marmoset ovaries were performed and run for approximately 6 months with very similar morphology and kinetics. Maximal passage number for C1 in this study was 23. Under C2, 3 different individual primary cultures were run for up to 8 passages and 13 weeks (late passages were considerably longer due to a decreased proliferation of the cells). Under C1, initially relatively small ovarian cell colonies (OCCs) formed which could be distinguished from the MEFs by the morphology of the cells and the colonies' boundaries (Fig.1A). The OCCs quickly increased in size forming big colonies with diameters up to $1000 \mu \mathrm{m}$ (Fig.1B) within a few days. The cells forming the OCCs under C1 exhibited an epitheloid phenotype (Fig.1G). The position of the nuclei was apical. In higher passages the individual OCCs became smaller (compare Fig.1B and C), but their number increased. Under C2 the sizes of OCCs were between 500 and $1000 \mu \mathrm{m}$ (Fig.1D-F). They exhibited, particularly in later passages, distinct borders (Fig. 1F). The cell morphology was also epitheloid with a very regular cuboidal shape and central nuclei (Fig.1H). Under both conditions, some OCCs developed in their centers a second layer of cells on top of the primary cell layer (e.g. Fig.1C). The cells, particularly under C2, showed a high nucleus:cytoplasm ratio. Together with the morphology of the colonies (e.g. Fig.1F) this was faintly reminiscent of primate ES cell colonies ${ }^{22}$. 

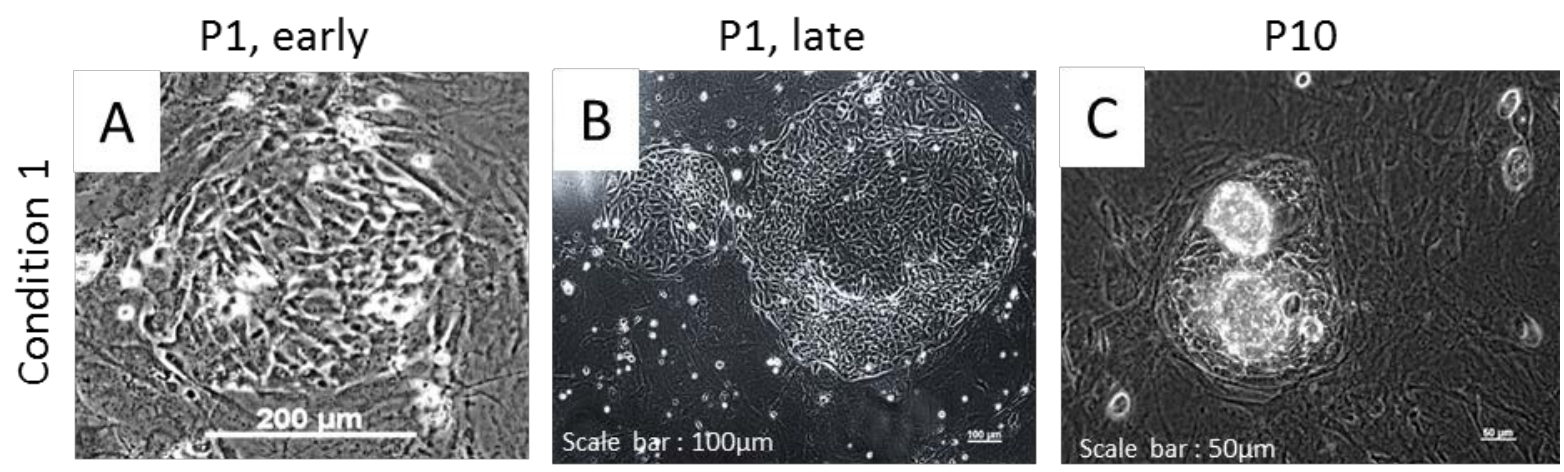

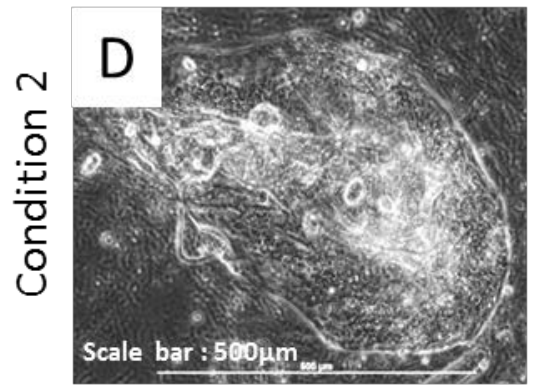

P1, late

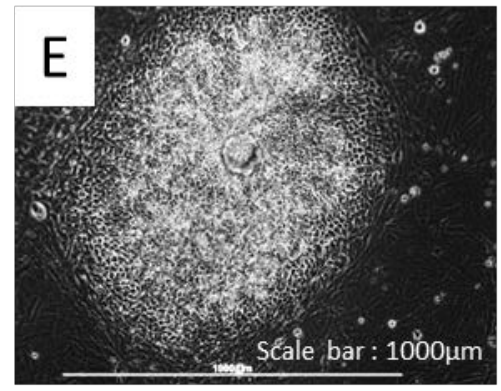

P3

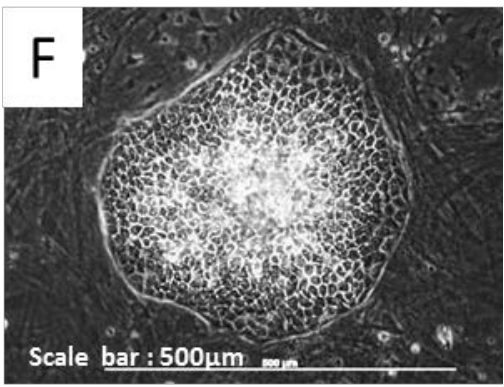

P6
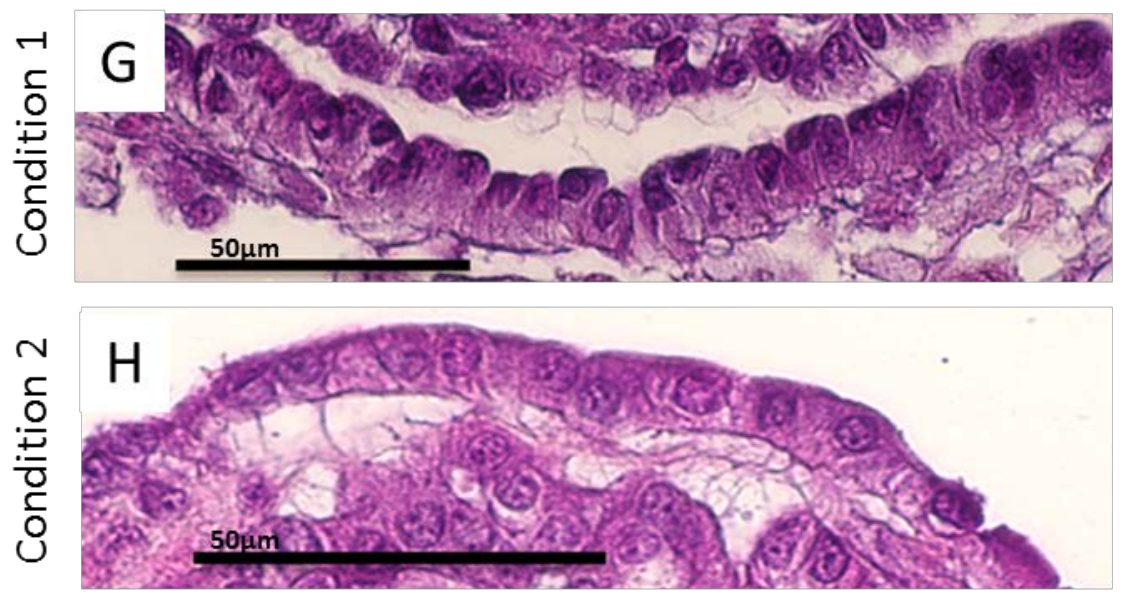

Fig.1: Morphology of ovarian cell colonies (OCCs). A-F) Morphology of cell colonies under condition 1 and condition 2 in the first passage and in higher passages. G, H) H\&E staining of cross sections of colonies developed under condition 1 and 2. Cells have an epithelial-like morphology with more apical nuclei under C1 and central nuclei under C2. 


\section{OCCs lack a germ cell population in early passages}

In order to compare the neonatal ovary-derived cell colonies from both conditions on the transcriptome level with reference samples we performed a comprehensive transcriptome analysis of early passage-OCCs by deep sequencing and compared the data set with the transcriptomes of neonatal ovaries, which served as starting material, marmoset ES cells as a reference for pluripotent cells and fibroblasts, which represent the prototypic mesenchymal cell. We used low passage number samples (between passage 1 and 4) in order to obtain data from original cells without extensive cell culture adaptation artefacts. Each individual sample's transcriptome was represented by at least 12 Mio. reads (Suppl. material Fig.1).

Fereydouni et al. Supp. Fig.1:

Number of reads per sample

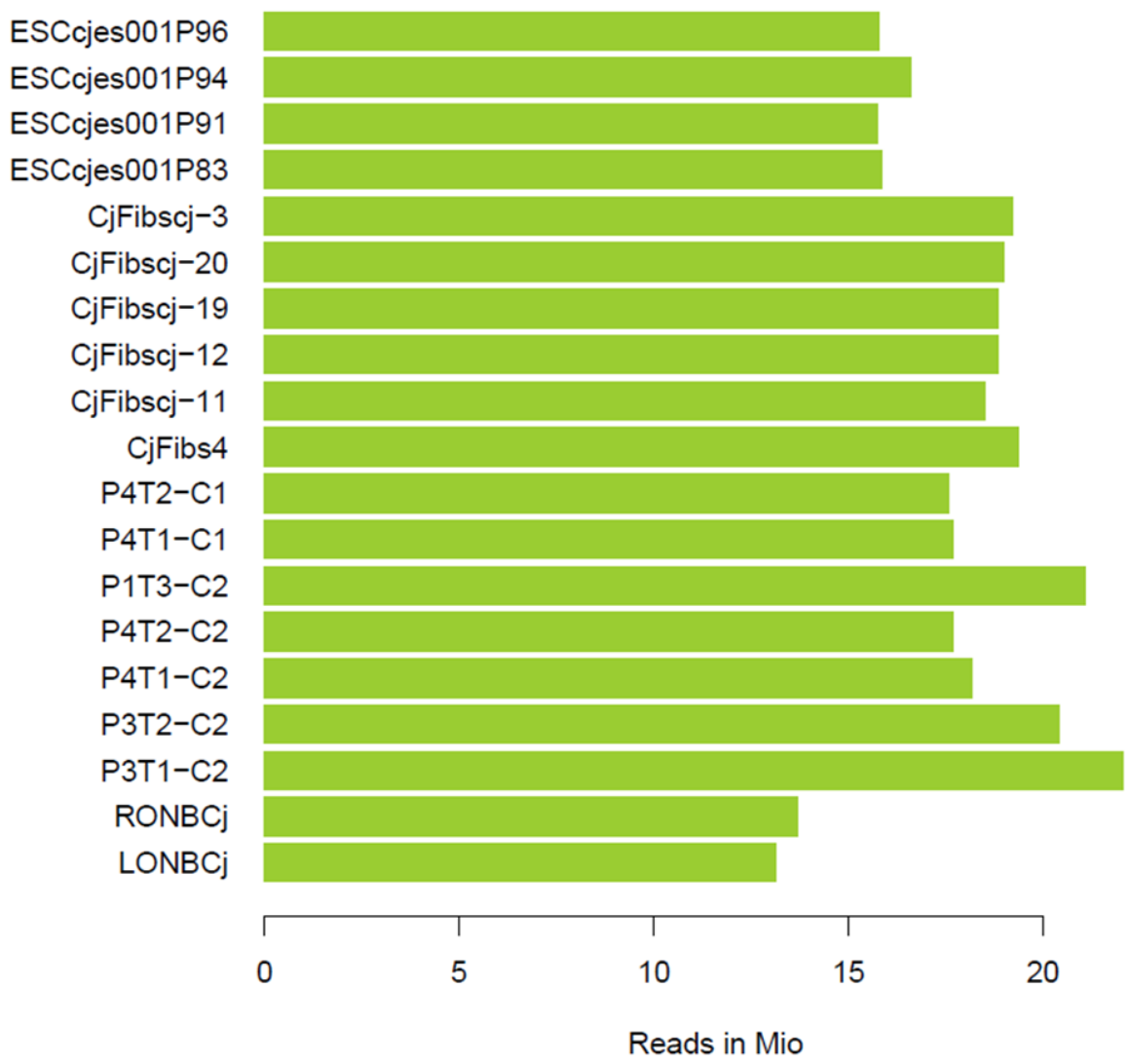


About 40.000 different transcripts were detected in each individual sample (Suppl. material Fig.2).

\section{Fereydouni et al. Supp. Fig.2: Number of detected transcripts per sample}

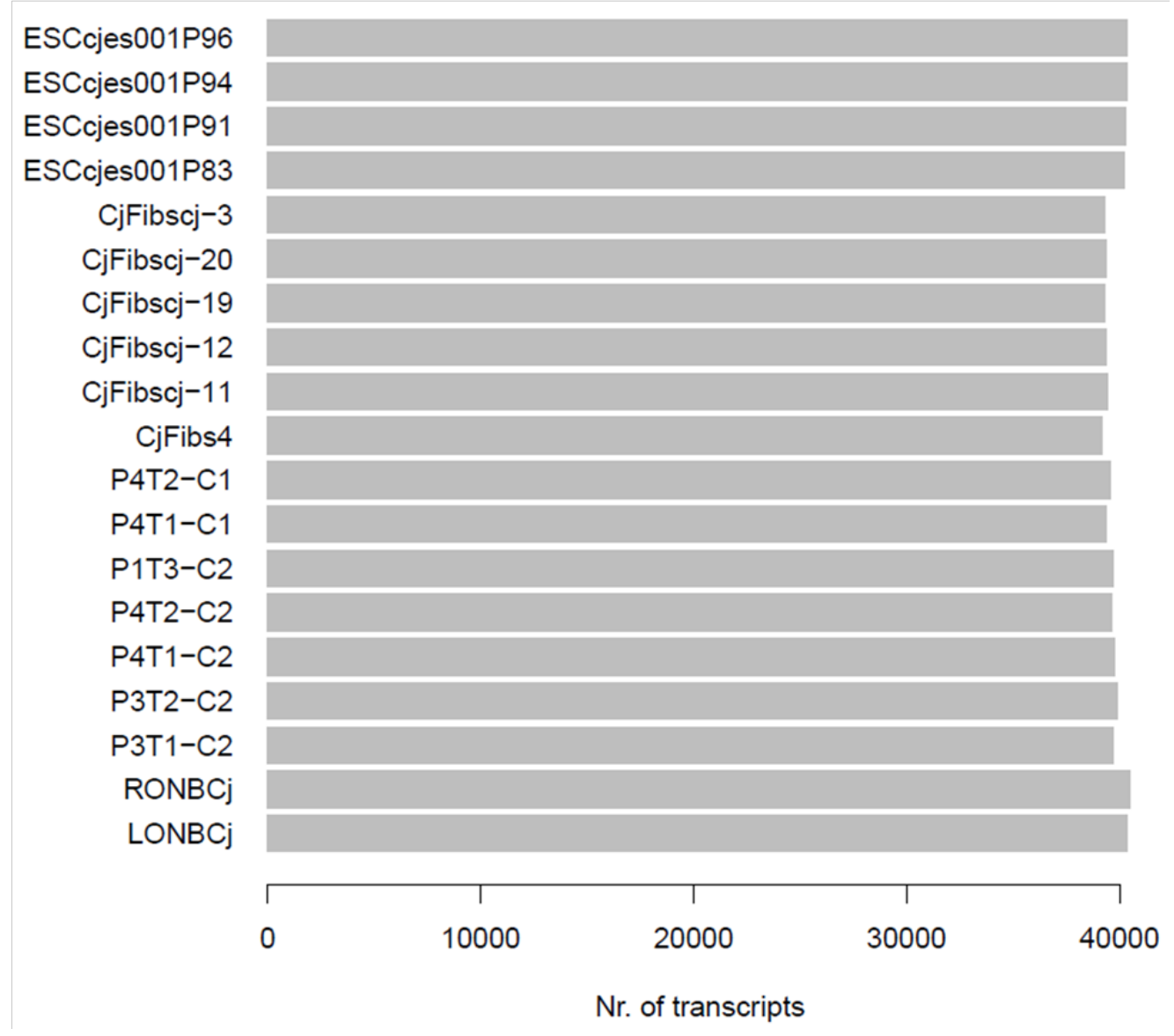

All ovarian cell culture samples, irrespective of the culture conditions, clustered together and were distinct from the three reference sample groups, i.e. native ovary, ES cells, and fibroblasts (Fig.2A). Importantly, OCCs were clearly separated from neonatal ovaries indicating fundamental differences between the transcriptomes of ovaries and OCCs. Notably, the top 50 
differentially expressed genes between native ovaries and OCCs from both conditions revealed two major facts (Fig.2B, C): 1. There was no gene among the top 50 genes that was higher expressed in the OCCs than in the native ovary suggesting that the OCCs represent a subpopulation of the whole cell population constituting the native ovary and that no completely different or novel cell type developed in culture, at least not in detectable quantities. 2. Among the top 50 differentially expressed genes are numerous germ cell-specific genes like MAEL, SPINK2, RNF17, TEX101, TEX12, TDRD9, MOV10L1, NOBOX, ZP3, FIGA, SOHLH2, DAZL, and SYCP2 (Fig.2B, C and suppl. List). In fact, many germ cell genes were completely undetectable in the transcriptomes of the OCCs or were detected only very sporadically even in passage 1 (i.e. primary culture of the cells after dissociation of the ovary). This strongly indicates the immediate loss of the neonatal ovarian germ cell population in cell culture. 

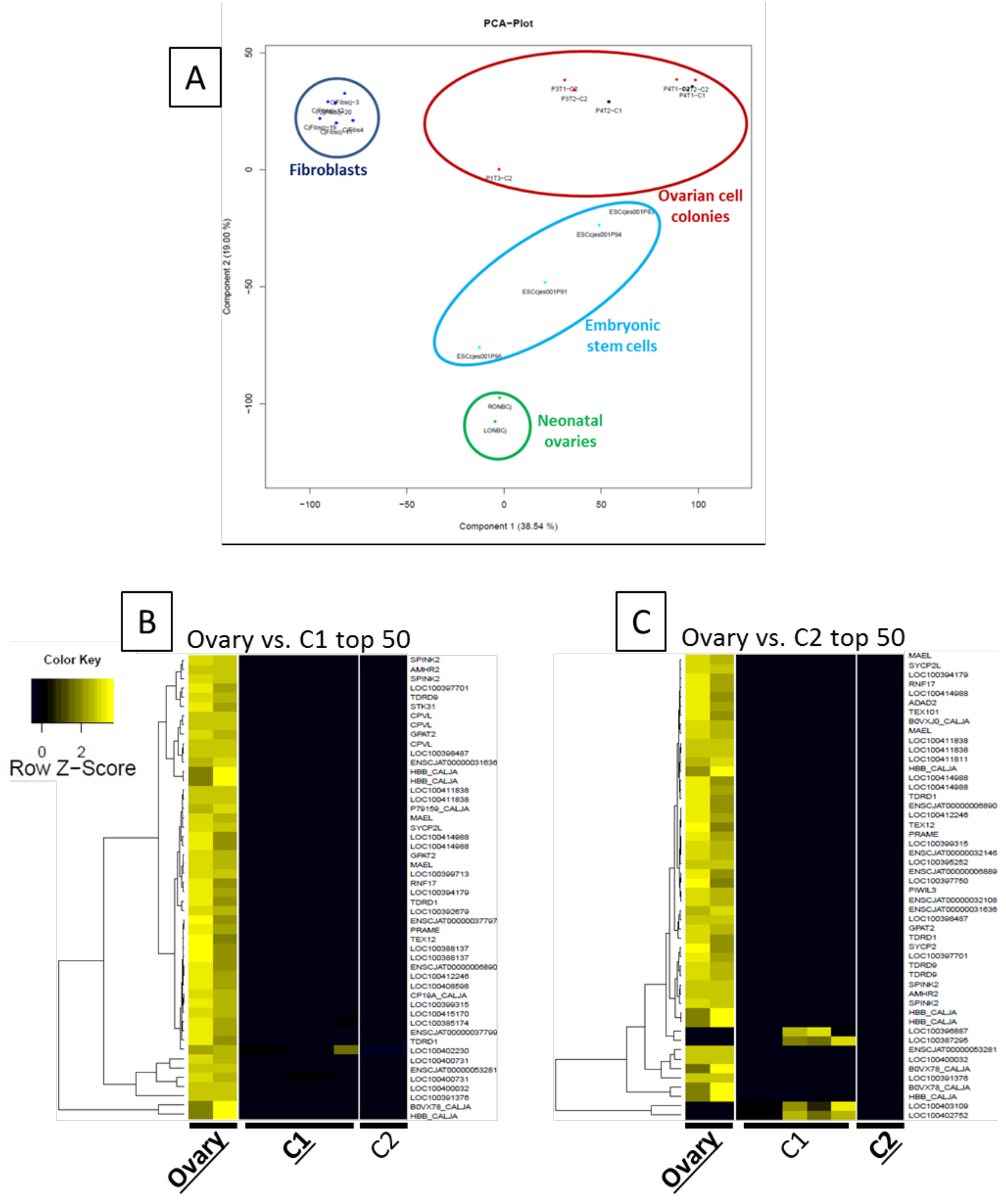

Fig.2: Trancriptome analysis of OCCs. A) Principal component analysis of the transcriptome analyses of ovarian cell colonies (OCC), neonatal ovaries, which served as starting material for 
OCC cultures, embryonic stem cells, and fibroblasts. The latter two served as reference samples. It is clearly evident that OCC transcriptomes differ from the neonatal ovaries' transcriptomes, irrespective of the culture conditions and the passage of the OCCs. However, ovaries, ES cells and OCC are more similar among each other than to fibroblasts (see component 1 , relative weight of 38.54\%). B) Top 50 differentially expressed genes between native neonatal ovary and OCCs under condition 1 (C1). Expression of these genes under condition 2 is shown as reference. For gene bank and Ensembl identifiers see Supp. Material, Table 1. C) Top 50 differentially expressed genes between native neonatal ovary and OCCs under condition 2 (C2). Expression of these genes under condition 1 is shown as reference. For gene bank and Ensembl identifiers see Supp. Material, Table 2.

We have recently shown that the neonatal marmoset monkey ovary contains primitive proliferating germ cells expressing the germ cell and pluripotency markers OCT4A, SALL4, LIN28, and the general germ cell marker VASA (DDX4) ${ }^{18}$. All these markers are only very poorly represented in the transcriptomes of the early passage OCCs or are even absent from these samples. We also failed to detect OCT4A, LIN28, or VASA on the protein level by a wellestablished immunohistochemistry protocol ${ }^{18}$ in early passage samples (data not shown). In order to quantify the expression of selected key marker genes in OCCs in relation to ES cells, fibroblasts and neonatal ovaries by an independent method and also at higher ( $>4)$ passages, we performed RT-qPCR for a number of pluripotency and (premeiotic) germ cell markers including OCT4A ${ }^{23}$, NANOG ${ }^{23}$, SALL4 ${ }^{24}$, LIN28 ${ }^{25}$, VASA ${ }^{26 ;}$ see also Fig. 5 , DAZL ${ }^{27}$, NOBOX ${ }^{28}$, DPPA3/STELLA/PGC7 ${ }^{29,30}$, PRDM1 $^{31}$, and PRDM14 ${ }^{32}$. The RT-qPCR data (Fig.3) confirm for both cell culture conditions that the most indicative pluripotency factors OCT4A and NANOG were not expressed in all cell culture samples analyzed (Fig.3). 
Condition 1
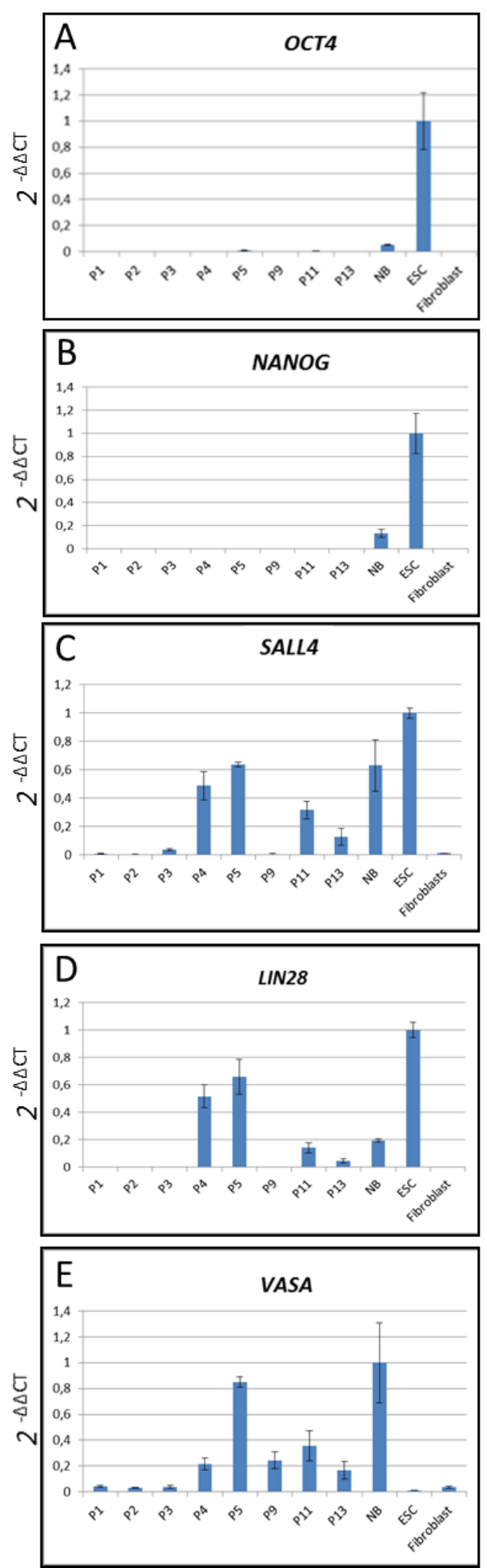

Condition 2
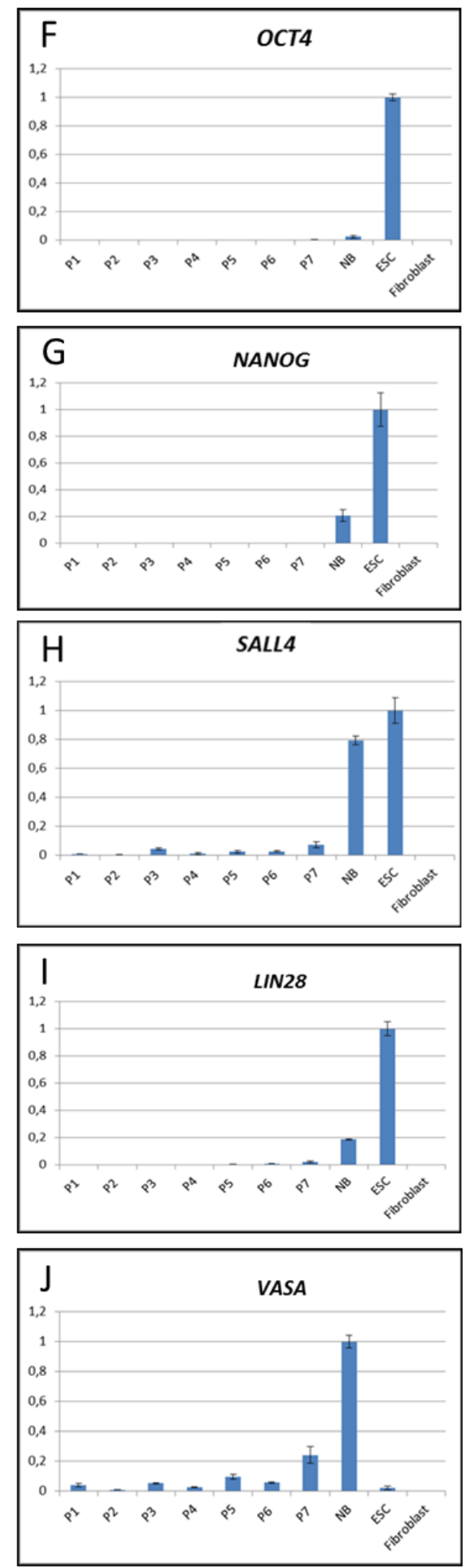

Fig.3: RT-qPCR analysis of OCCs in different passages. Real-time quantitative RT-PCR for selected key pluripotency and germ cell markers in OCCs under C1 and C2. OCT4, NANOG, 
SALL4, and LIN28 are all expressed in pluripotent stem cells as well as in primitive germ cells. VASA is a germ cell marker

Under C2, also SALL4 and LIN28 were absent or very low compared to ES cells and neonatal ovary. During the first passages VASA was also very low and increased only slightly at higher passages. In contrast, under C1, SALL4, LIN28 and VASA were robustly induced in passages $>$ P3. In order to further substantiate these findings for C1, we also tested the expression of PRDM1, PRDM14, DAZL, DPPA3, and NOBOX in the C1 samples (Fig.4). DAZL, DPPA3, and $N O B O X$ as specific germ-cell genes were absent or very low at low passages, which is in concordance with the data shown in Fig.3. In contrast, PRDM1 and PRDM14, early germ cell specification genes, were robustly expressed in all cell culture samples in the range of the positive controls. These data indicate that C1 supports the culture and probably also the selection of cells that have the potential to (re-)express a set of (premeiotic) female germ cell markers. 

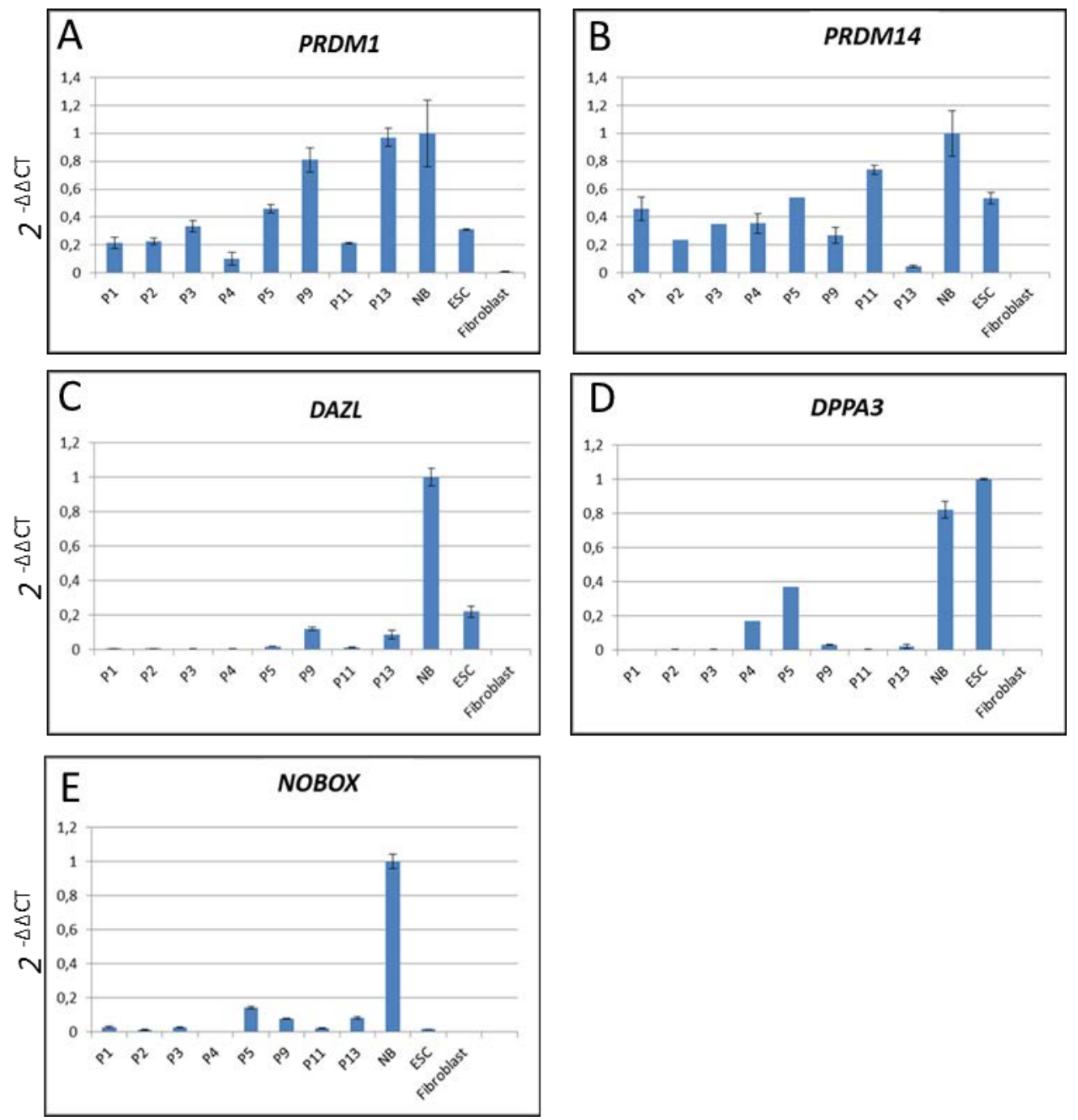

Fig.4: Expression of additional markers in OCCs. PRDM1, PRDM14 and DPPA3 are necessary for germ cell specification. They are also expressed by ES cells. DAZL and NOBOX are general and female germ cell markers, respectively. 


\section{The OCCs under C1 generate oocyte-like cells}

Both cell culture conditions led to the formation of large colonies (see Fig.1). However, only the OCCs under condition 1 generated large, free-floating spherical cells, which we termed oocytelike cells (OLCs). OLCs had a morphology resembling immature oocytes. Their diameter ranged from 20 to approximately $50 \mu \mathrm{m}$ (Fig.5A). However, we never observed a zona pellucida. Importantly, OLCs developed under C1 even after 20 passages and more than 5 months of culture, but not in passages $<4$. To initially characterize the OLCs, we tested the expression of key pluripotency and germ cell markers by RT-qPCR. We collected 28 OLCs and randomly allocated the cells to one of two groups (OLCs1 and OLCs2), which were then analyzed. OCT4A, NANOG, and LIN28 were low in OLCs compared to ES cells and neonatal ovaries (Fig.5B-D). SALL4 was robustly expressed (Fig.5E) in the range of the controls. PRDM14, DPPA3, DAZL, VASA, and NOBOX were much higher in OLCs than in neonatal ovary indicating very robust expression of these germ cell markers in OLCs. Importantly, DAZL, VASA, and NOBOX are specific germ line markers and are not also expressed by ES cells (Fig.5h-L) 

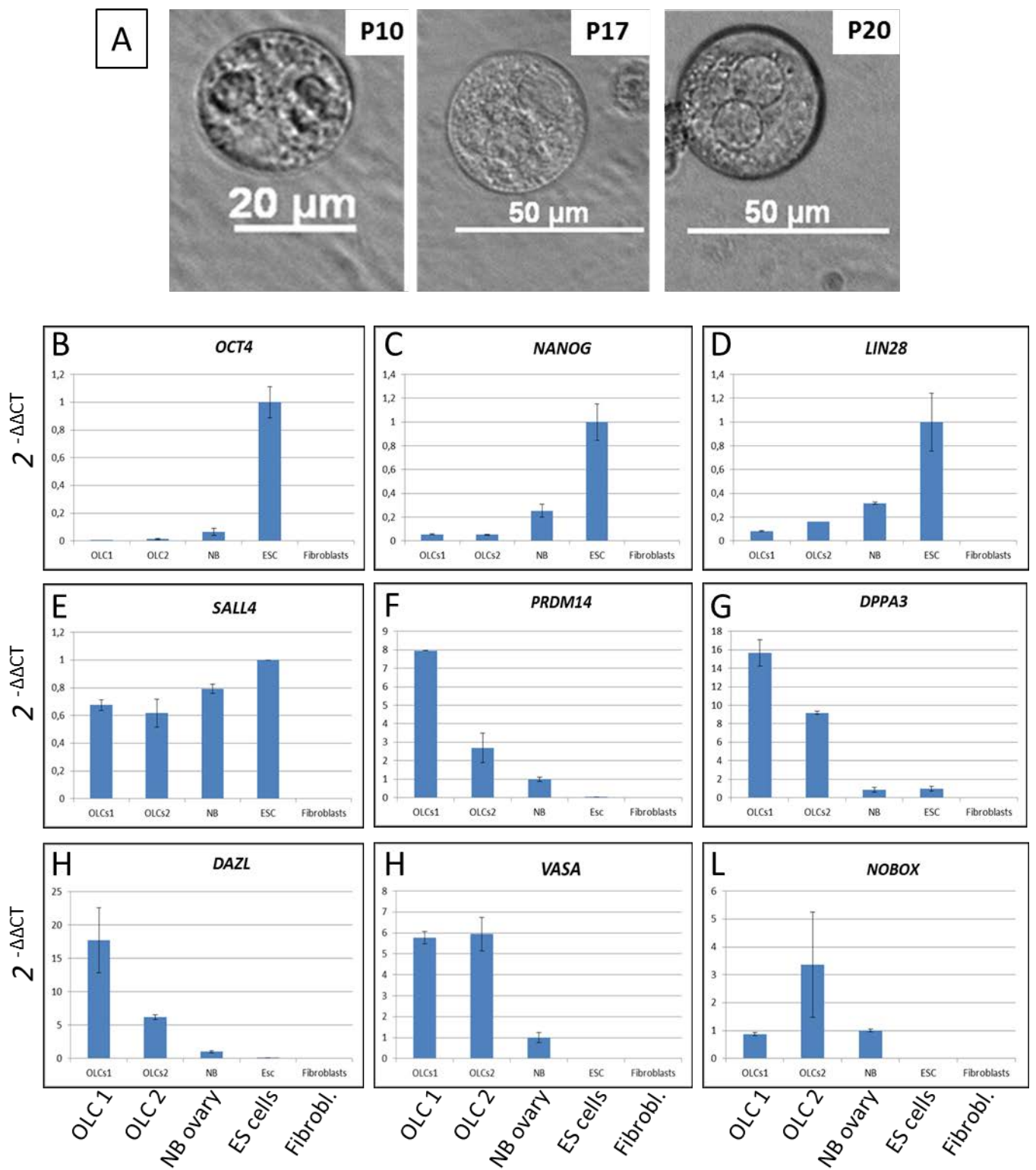

Fig.5: Oocyte-like cells derived from OCCs. A) Oocyte-like cells that spontaneously developed under condition 1 even in high cell culture passages. The cells were freely floating in the cell culture medium and had a diameter of approximately $50 \mu \mathrm{m}$. B-L) Oocyte-like cells express pluripotency and germ cell markers. Relative mRNA levels of selected pluripotency and germ cell markers in oocyte-like cells as revealed by real-time quantitative RT-PCR. For OCT4A, SALL4, and LIN28, ES cells were used as positive control. Neonatal ovary was used as positive control for the germ cell markers. Fibroblasts served as biological negative control. 
As the above mentioned markers. Hence, these three markers strongly corroborate the germ cell identity of the OLCs. Comparable data were obtained when the gene expression was related to $\beta$ ACTIN instead of GAPDH validating our data based on GAPDH normalization. In order to further corroborate the germ line identity of the OLCs we aimed at detecting also VASA protein in the OLCs. First we carefully characterized the VASA antibody to prevent misleading antibody-based results as we ${ }^{33}$ and others ${ }^{34}$ recently described. In western blot analysis a very intense and prominent band of the expected size of $\sim 85 \mathrm{kDa}$ was detected exclusively in testis indicating a high specificity of the VASA antibody (Fig.6A). Lack of a VASA signal in the ovary was most likely due to the fact that the ovary was from an old monkey with an exhausted ovarian germ cell reserve. We also tested the VASA antibody in immunohistochemistry on tissue sections from adult marmoset testis and ovary. In both sexes, the antibody very robustly and specifically detected an epitope in germ cells resulting in clear cytoplasmic germ cell labeling. These findings demonstrate a high specificity of the VASA antibody used in this study. We then used this antibody to detect potential OLCs in OCCs. When we fixed the OCCs of the $5^{\text {th }}$ passage under C1 in situ, large cells with strongly condensed chromatin, as indicated by strong DAPI fluorescence in Fig. 6D, were labeled by the VASA antibody (Fig.6E), while surrounding cells exhibited only weak background staining. The diameter of the labeled cell was approximately $50 \mu \mathrm{m}$ like the diameter of the OLCs shown in Fig.5. We also detached the cell cultures from the culture dish and processed them - like the testis and ovary shown in Fig.6B and C - for immunohistochemistry. We found isolated cells that were clearly stained for VASA by IHC (Fig.6F, G). These data demonstrate that there are isolated VASA-positive oocyte-like cells in the cultures derived from neonatal marmoset monkey ovary even after prolonged periods of time. 

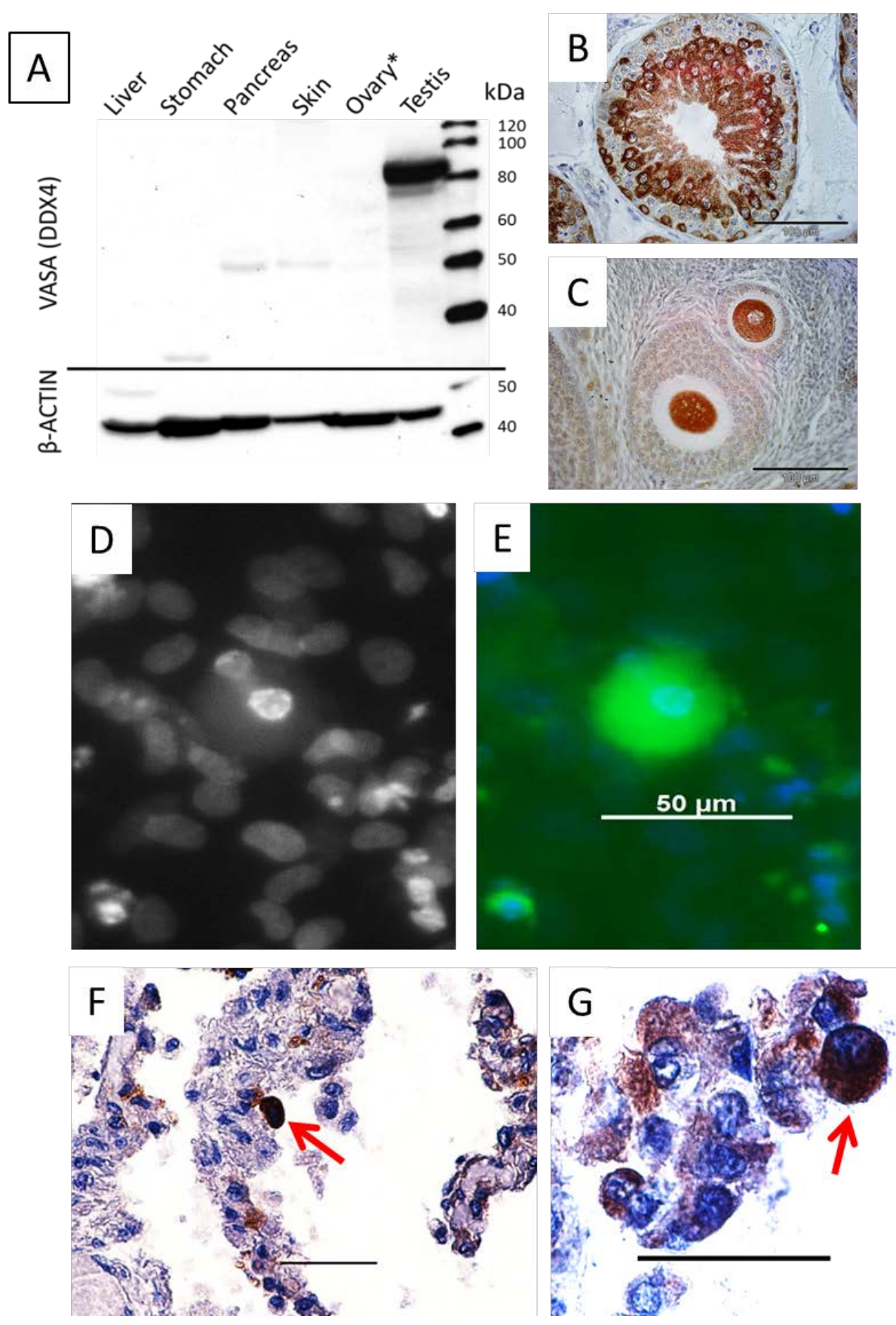

Fig.6: Characterization of the VASA antibody and detection of VASA-positive cells in OCCs under condition 1. A) Western blot analysis using marmoset monkey protein samples demonstrates the specificity of the VASA antibody. B and C) Immunhistochemical application of the VASA antibody to marmoset gonads showed germ cell-specific labeling in testis and in the ovary. D) DAPI staining of a part of an OCC. Note the intensely stained nucleus in the central part. E) Same area shown in D. The large cell containing the intensely stained nucleus clearly stains for VASA. F, G) Examples of isolated VASA-positive cells (arrows) in sections of paraffin-embedded OCCs under condition 1. 


\section{The relative abundance of the markers is decreasing within one passage}

To obtain initial information on the transcript abundance of the markers during the OCC development over time within one passage, we isolated RNA from duplicate samples from OCCs after 2, 4, 6, and 8 days. OCT4A, NANOG, and LIN28 were very low or absent (Fig.7A-C). In contrast, SALL4 and VASA were robustly detectable in all samples (Fig.7D, E). Both markers exhibited a high abundance at day 2. Later time points (days 4-8) showed a decrease in transcript abundance relative to GAPDH probably reflecting a higher proliferation rate of the markernegative (but GAPDH expressing) cells compared to the marker positive cells leading to a dilution effect of the VASA and SALL4-positive cells. 

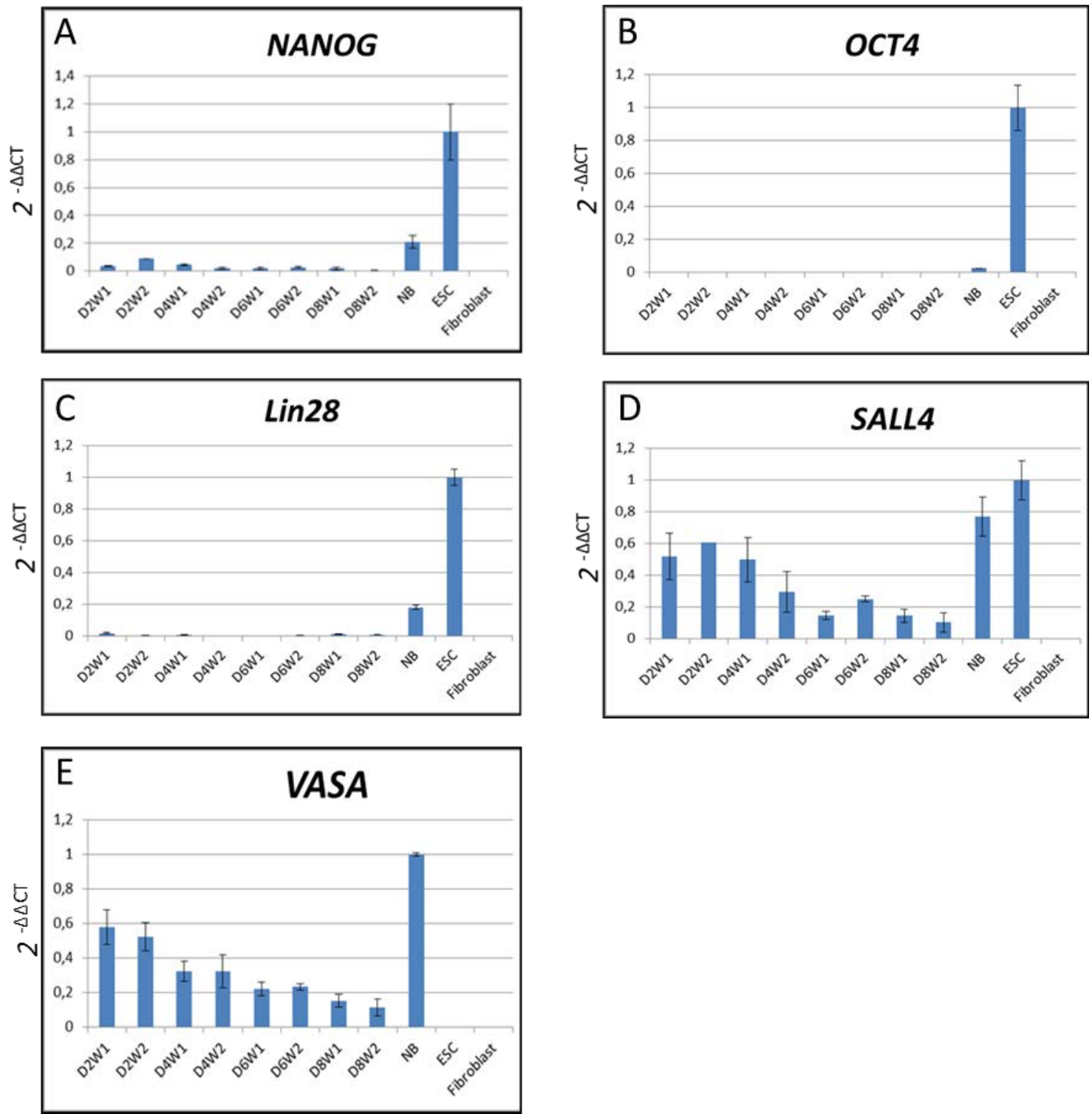

Fig.7: Pluripotency and germ cell marker mRNA abundance during the development of OCCs within one passage under condition 1 as revealed by real-time quantitative PCR. Positive controls for OCT4A, SALL4, and LIN28 were ES cells. Neonatal ovary was used as positive control for the germ cell marker VASA. Relative abundance of SALL4 and VASA decreased during the culture period. 


\section{No production of sex steroids by the OCCs}

Since we were wondering whether the OCCs have the ability to produce female sex steroids like specific cells of the ovary in vivo, we tested medium samples from low and high culture passages after several days without medium change. Samples were analyzed for estradiol, which is primarily produced by ovarian granulosa cells, and progesterone, which is synthetized by the cells of the Corpus luteum. No estradiol and progesterone were detected in medium samples.

\section{Neither teratoma nor ovarian tissue formation in a subcutaneous transplantation assay}

Subcutaneous transplantation of cells into immune-deficient mice is a useful approach to assay cells with regard to their long-term survival, reconstruction, and differentiation capabilities. Pluripotency of primate stem cells is usually tested in this way (teratoma formation assay). Moreover, we have recently shown that single cell suspensions derived from dissociated neonatal monkey testis can reconstitute complex testis tissue after transplantation into immune-deficient mice $^{21}$. In order to test whether the OCCs have the ability to form complex (ovarian) tissue under the "in vivo" conditions after transplantation, we injected $\sim 10^{6}$ cells per mouse from the $5^{\text {th }}$ passage subcutaneously into 4 female adult NOD-SCID mice. Tissues from the injection site were collected for histological analysis after 15 weeks. No ovary-like tissue or teratoma was found (data not shown). 


\section{Discussion}

A highly controversial debate characterized the last decade of ovarian germ cell research in mammals: the contentious point was the presence of mitotically active germ line stem cells in the postnatal ovary of mammals. Several reports provided data supporting the presence of ovarian germ line stem cells in postnatal mouse ovaries e.g. ${ }^{10,12,13,35}$, while other studies failed to identify female germ line stem cells ${ }^{7,8}$ and thereby supported the classical view of ovarian biology ${ }^{1}$. In primates including humans, the published data are similarly controversial and still not fully conclusive. Byskov, Hoyer, Yding Andersen, Kristensen, Jespersen, Mollgard ${ }^{3}$ failed to detect oogonia, which may be candidate cells for ovarian stem cells, in the postnatal human ovary older than two years, and even in younger postnatal ovaries the stem cell marker OCT4 was detectable only very rarely. We also recently failed to detect pluripotency and stem cell marker-positive cells in marmoset ovaries older than a year ${ }^{18}$. On the other hand, White, Woods, Takai, Ishihara, Seki, Tilly ${ }^{14}$ isolated mitotically active cells from human adult ovarian cortex that had the potential to form oocyte-like cells in vitro and to form ovarian follicles in a combined allo-xenografting approach. Recently, however, Yuan, Zhang, Wang, Liu, Mao, Yin, Ye, Liu, Han, Gao, Cheng, Keefe, Liu ${ }^{9}$ failed to provide evidence for mitotically active germ line stem cells in rhesus monkeys (Macaca mulatta) and mice concluding that adult ovaries do not undergo germ cell renewal.

Two excellent reviews recently put the discussion in an evolutionary perspective ${ }^{36,37}$ since in non-mammalian species like flies (Drosophila) or fish (Medaka) ovarian germ cell-renewal and the presence of ovarian germ line stem cells is well-established. Almost forgotten, also in a group of “lower” non-human primates (formerly called “prosimians”) germ cell proliferation in

adult ovaries has been described decades ago ${ }^{38,39}$. The former primate group of simians can be 
subdivided into old world primates and new world primates. Humans and rhesus macaques belong to the old world primates. Following the comparative evolutionary approach, we investigated the marmoset monkey, which is a representative of the new world monkeys and a well-established laboratory animal frequently used in stem cell and reproductive biology. In a previous study ${ }^{18}$ we showed by immunohistochemical marker detection (OCT4A, LIN28, SALL4, KI67) that the marmoset monkey ovary is very primitive at birth and that there are numerous proliferating premeiotic germ cells present, which is in clear contrast to the human and the macaque ${ }^{3,40}$. In the present work we studied marmoset monkey germ cell development in cell cultures derived from neonatal ovaries.

Seeding of the marmoset monkey ovarian cell suspension onto the MEF cells resulted in the development of cell colonies morphologically resembling colonies which have been observed previously by different other groups for human ${ }^{41}$ and mouse ${ }^{13,42}$ ovarian cell cultures. However, while these studies report the robust expression of pluripotency markers such as OCT4 and NANOG and therefore claim an ES cell-like character of the cells ${ }^{42}$, we failed to detect these core pluripotency markers in marmoset ovarian cell cultures on the transcript and on the protein level (latter not shown), although our starting material, i.e. neonatal ovary, was positive for these factors. This is also in contrast to a very recent publication on pig ovarian stem cells. ${ }^{43}$ derived putative stem cells from adult pig ovary that gave rise to germ cell-like cells corresponding to primordial germ cells. However, these cells, unlike the cells described in our present study, also robustly expressed pluripotency factors such as OCT4 and NANOG. Moreover, the phenotype of the pig cells in culture was very different from the colonies observed by us and others e.g. ${ }^{42}$. Interestingly, however, despite the clearly different starting conditions, both, our and Bui's cell culture system led to the development of large oocyt-like cells. 
Importantly, in addition to the absence of the pluripotency factors, in most samples analyzed by deep sequencing we did not detect even a single DAZL, MAEL, RNF17, TEX12, TEX101, or a TDRD1transcript, while all these germ cell transcripts were abundant in the neonatal ovary samples indicating the complete loss of germ cells in the ovarian cell cultures. In summary of this part, the marmoset monkey OCCs are neither germ cells nor pluripotent stem cells. Furthermore, they also do not contain a substantial fraction of these cells. However, from passage 4 onwards, we observed under condition 1 the development of oocyte-like cells strongly expressing the germ cell genes VASA, DAZL, NOBOX, DPPA3 and SALL4, while the OCT4A, NANOG and LIN28 were relatively low in OLCs. This suggests a late premeiotic stage of the OLCs.

We have previously experienced severe problems with the specificity of antibodies ${ }^{33}$. Therefore, we carefully characterized the VASA antibody which we used in this study and found that it specifically detects also marmoset monkey VASA protein. In summary of the transcript and protein analysis of the OLCs in the different passages and under different conditions, OLCs developed only under condition 1 and were first observed in passage 4 and still developed at high passages (>20) after more than 5 months of culture. They robustly expressed the general germ cell marker VASA as well as additional germ cell / oocyte markers. On the other hand, we failed to detect pluripotent stem / premeiotic germ cell markers in low OCC passages. These data suggest that there are stem and / or progenitor cells present in the early OCC passages that lack classical premeiotic germ cell characteristics, but have the potential to develop OLCs in longterm cultures. So far, we were not able to identify these cells. Moreover, it is still unclear whether these putative germ line stem cells have a real in vivo-counterpart in the ovary or whether they only develop under ex vivo cell culture conditions. One candidate tissue for the 
presence of ovarian stem cells could be the ovarian surface epithelium, which is discussed to be a multipotent tissue possibly harboring a stem or progenitor cell type ${ }^{16}$. However, it is remarkable that the most convincing evidence for FGSC is based on experiments involving cell culture, i.e. artificial conditions with regard to tissue integrity and a putative stem cell niche, while pure in vivo / in situ studies so far mostly failed to clearly demonstrate the existence of FGSC.

We tested two different cell culture conditions. However, only DMDM/F12 plus FBS was able to support oocyte-like cell development while ES cell culture conditions lacking FBS did not produce oocyte-like cells. This difference gives a first hint at the requirements for OLC differentiation and may serve as a starting point for future cell culture refinements in order to improve the quantity and the differentiation of the OLCs.

\section{Conclusion and outlook}

In conclusion, we have established a non-human primate cell culture system that allows the longterm culture and development of OLCs from a non-human primate species. The cultured cells, however, are neither pluripotent stem cells nor germ (line stem) cells, as has been suggested in previous reports ${ }^{13,41,42}$.

Future experiments will aim at the identification and functional characterization of the stem /

progenitor cell population which has the potential to give rise to oocyte-like cells including transplantation into monkey ovaries after genetic labeling of the cells. However, whether putative FGSCs may play a functional role in the ovary under physiological conditions remains to be investigated. 


\section{Acknowledgement}

We appreciate the excellent assistance and the support of Nicole Umland, Angelina Berenson and Gesche Spehlbrink. We are also very thankful to Katharina Debowski for providing the ES cell RNA and Ellen Wiese for administrative support and the members of the animal facility for excellent animal husbandry. The support of Bentolhoda Fereydouni by the scholarship of the Deutscher Akademischer Austauschdienst (DAAD) is gratefully acknowledged. 


\section{References}

1. Zuckerman S. The number of oocytes in the mature ovary. Recent progress in hormone research. 1951;6:63-108.

2. Byskov AG, Faddy MJ, Lemmen JG, et al. Eggs forever? Differentiation; research in biological diversity. 2005;73:438-446.

3. Byskov AG, Hoyer PE, Yding Andersen C, et al. No evidence for the presence of oogonia in the human ovary after their final clearance during the first two years of life. Human reproduction. 2011;26:2129-2139.

4. Liu Y, Wu C, Lyu Q, et al. Germline stem cells and neo-oogenesis in the adult human ovary. Developmental biology. 2007;306:112-120.

5. Bendsen E, Byskov AG, Andersen CY, et al. Number of germ cells and somatic cells in human fetal ovaries during the first weeks after sex differentiation. Human reproduction. 2006;21:3035.

6. Stoop H, Honecker F, Cools $\mathrm{M}$, et al. Differentiation and development of human female germ cells during prenatal gonadogenesis: an immunohistochemical study. Human reproduction. 2005;20:1466-1476.

7. Zhang $\mathrm{H}$, Zheng $\mathrm{W}$, Shen $\mathrm{Y}$, et al. Experimental evidence showing that no mitotically active female germline progenitors exist in postnatal mouse ovaries. Proceedings of the National Academy of Sciences of the United States of America. 2012;109:12580-12585.

8. Lei L, Spradling AC. Female mice lack adult germ-line stem cells but sustain oogenesis using stable primordial follicles. Proceedings of the National Academy of Sciences of the United States of America. 2013;110:8585-8590.

9. Yuan J, Zhang D, Wang $L$, et al. No evidence for neo-oogenesis may link to ovarian senescence in adult monkey. Stem cells. 2013;31:2538-2550.

10. Johnson J, Bagley J, Skaznik-Wikiel $M$, et al. Oocyte generation in adult mammalian ovaries by putative germ cells in bone marrow and peripheral blood. Cell. 2005;122:303-315.

11. Johnson J, Canning J, Kaneko T, et al. Germline stem cells and follicular renewal in the postnatal mammalian ovary. Nature. 2004;428:145-150.

12. Zou K, Yuan Z, Yang Z, et al. Production of offspring from a germline stem cell line derived from neonatal ovaries. Nature cell biology. 2009;11:631-636.

13. Pacchiarotti J, Maki C, Ramos T, et al. Differentiation potential of germ line stem cells derived from the postnatal mouse ovary. Differentiation; research in biological diversity. 2010;79:159170.

14. White YA, Woods DC, Takai Y, et al. Oocyte formation by mitotically active germ cells purified from ovaries of reproductive-age women. Nature medicine. 2012;18:413-421.

15. Parte S, Bhartiya D, Telang J, et al. Detection, characterization, and spontaneous differentiation in vitro of very small embryonic-like putative stem cells in adult mammalian ovary. Stem cells and development. 2011;20:1451-1464.

16. Bukovsky A, Caudle MR, Virant-Klun I, et al. Immune physiology and oogenesis in fetal and adult humans, ovarian infertility, and totipotency of adult ovarian stem cells. Birth defects research. Part C, Embryo today : reviews. 2009;87:64-89.

17. Virant-Klun I, Stimpfel M, Skutella T. Ovarian pluripotent/multipotent stem cells and in vitro oogenesis in mammals. Histology and histopathology. 2011;26:1071-1082.

18. Fereydouni B, Drummer C, Aeckerle N, et al. The neonatal marmoset monkey ovary is very primitive exhibiting many oogonia. Reproduction. 2014. 
19. Heistermann M, Tari S, Hodges JK. Measurement of faecal steroids for monitoring ovarian function in New World primates, Callitrichidae. Journal of reproduction and fertility. 1993;99:243-251.

20. Heistermann $M$, Finke $M$, Hodges JK. Assessment of female reproductive status in captivehoused Hanuman langurs (Presbytis entellus) by measurement of urinary and fecal steroid excretion patterns. American journal of primatology. 1995;37:275-284.

21. Aeckerle N, Dressel R, Behr R. Grafting of Neonatal Marmoset Monkey Testicular Single-Cell Suspensions into Immunodeficient Mice Leads to ex situ Testicular Cord Neomorphogenesis. Cells, tissues, organs. 2013;198:209-220.

22. Muller T, Fleischmann G, Eildermann $\mathrm{K}$, et al. A novel embryonic stem cell line derived from the common marmoset monkey (Callithrix jacchus) exhibiting germ cell-like characteristics. Human reproduction. 2009;24:1359-1372.

23. Perrett RM, Turnpenny L, Eckert JJ, et al. The early human germ cell lineage does not express SOX2 during in vivo development or upon in vitro culture. Biology of reproduction. 2008;78:852858.

24. Eildermann K, Aeckerle N, Debowski K, et al. Developmental expression of the pluripotency factor sal-like protein 4 in the monkey, human and mouse testis: restriction to premeiotic germ cells. Cells, tissues, organs. 2012;196:206-220.

25. Aeckerle N, Eildermann K, Drummer C, et al. The pluripotency factor LIN28 in monkey and human testes: a marker for spermatogonial stem cells? Molecular human reproduction. 2012;18:477-488.

26. Castrillon DH, Quade BJ, Wang TY, et al. The human VASA gene is specifically expressed in the germ cell lineage. Proceedings of the National Academy of Sciences of the United States of America. 2000;97:9585-9590.

27. Lin Y, Gill ME, Koubova J, et al. Germ cell-intrinsic and -extrinsic factors govern meiotic initiation in mouse embryos. Science. 2008;322:1685-1687.

28. Rajkovic A, Pangas SA, Ballow D, et al. NOBOX deficiency disrupts early folliculogenesis and oocyte-specific gene expression. Science. 2004;305:1157-1159.

29. Liu YJ, Nakamura T, Nakano T. Essential role of DPPA3 for chromatin condensation in mouse oocytogenesis. Biology of reproduction. 2012;86:40.

30. Sato M, Kimura T, Kurokawa K, et al. Identification of PGC7, a new gene expressed specifically in preimplantation embryos and germ cells. Mechanisms of development. 2002;113:91-94.

31. Ohinata $Y$, Payer $B, O^{\prime}$ Carroll $D$, et al. Blimp1 is a critical determinant of the germ cell lineage in mice. Nature. 2005;436:207-213.

32. Yamaji M, Seki Y, Kurimoto K, et al. Critical function of Prdm14 for the establishment of the germ cell lineage in mice. Nature genetics. 2008;40:1016-1022.

33. Warthemann R, Eildermann K, Debowski K, et al. False-positive antibody signals for the pluripotency factor OCT4A (POU5F1) in testis-derived cells may lead to erroneous data and misinterpretations. Molecular human reproduction. 2012;18:605-612.

34. Ivell R, Teerds K, Hoffman GE. Proper application of antibodies for immunohistochemical detection: antibody crimes and how to prevent them. Endocrinology. 2014;155:676-687.

35. Johnson $\mathrm{MH}, \mathrm{McConnell} \mathrm{JM}$. Lineage allocation and cell polarity during mouse embryogenesis. Seminars in cell \& developmental biology. 2004;15:583-597.

36. De Felici $M$, Barrios F. Seeking the origin of female germline stem cells in the mammalian ovary. Reproduction. 2013;146:R125-130.

37. Hanna CB, Hennebold JD. Ovarian germline stem cells: an unlimited source of oocytes? Fertility and sterility. 2014;101:20-30. 
38. Ioannou JM. Oogenesis in adult prosimians. Journal of embryology and experimental morphology. 1967;17:139-145.

39. Butler H, Juma MB. Oogenesis in an adult prosimian. Nature. 1970;226:552-553.

40. van Wagenen G, Simpson ME. Postnatal development of the ovary in Homo sapiens and Macaca mulatta and Induction of Ovulation in the Macaque. New Haven and London: Yale University Press; 1973: 1-306.

41. Stimpfel M, Skutella T, Cvjeticanin B, et al. Isolation, characterization and differentiation of cells expressing pluripotent/multipotent markers from adult human ovaries. Cell and tissue research. 2013;354:593-607.

42. Gong SP, Lee ST, Lee EJ, et al. Embryonic stem cell-like cells established by culture of adult ovarian cells in mice. Fertility and sterility. 2010;93:2594-2601, 2601 e2591-2599.

43. Bui HT, Van Thuan N, Kwon DN, et al. Identification and characterization of putative stem cells in the adult pig ovary. Development. 2014;141:2235-2244. 


\section{Summary of the results}

\subsection{Histology of the neonatal marmoset ovary}

The whole ovary of neonatal marmoset monkey is covered by the Ovarian Surface Epithelium (OSE). Central part of the ovary is the medulla which is mainly vascularized connective tissue (Fereydouni et al. 2014; Figure 1A). Directly underneath the OSE there is a thin layer of cells in which the different cell types are histologically difficult to distinguish. We named this layer indifferent cortical zone (ICZ) of the neonatal marmoset ovary. It contains primitive germ and somatic cells (Fereydouni et al. 2014; Figure 1B). In the immature cortical region, the germ cells are still in clusters or nests of cells. In Figure 2B the ICZ layer is shown at the higher magnification. The ICZ contains primitive germ and somatic cells. At the border between the ICZ and the cortex, germ cells are seen in the nests which contain germ cells with an oogonia phenotype and germ cell with an oocyte (meiotic) phenotype (Fereydouni et al. 2014; Figure1B). 


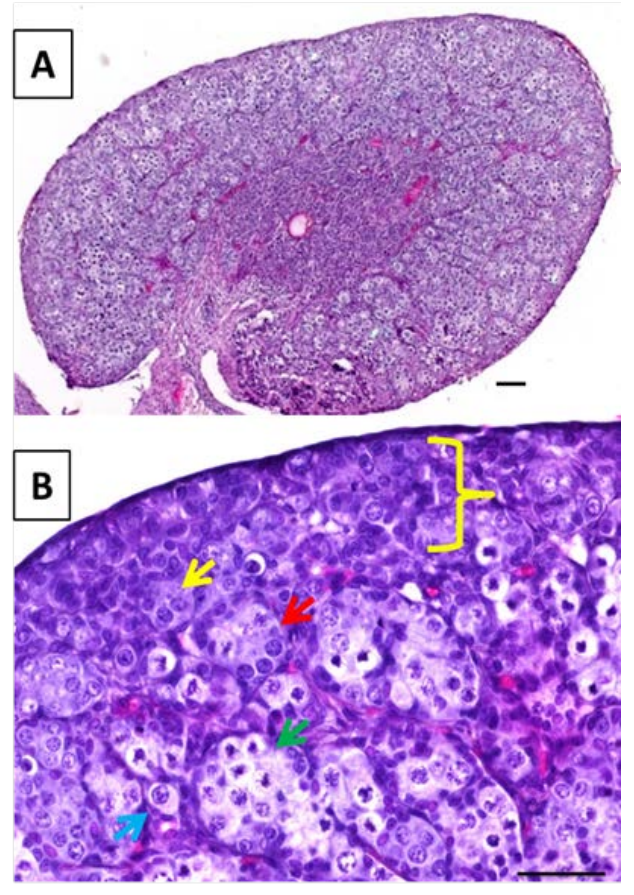

Figure 1: Histology of the neonatal common marmoset monkey ovary. A) Shows an overview of a whole cross section of a neonatal ovary. B) Higher magnification of the peripheral zone. The yellow bracket indicted the ICZ, the yellow arrow points to a nest of oogonia, the red arrow shows one nest containing some oogonia and some oocytes. The green arrow marks a nest of oocytes and the blue arrow points to a primordial follicle (Fereydouni et al., 2014). The scale bar represents $50 \mu \mathrm{m}$.

\subsection{Neonatal marmoset ovaries contain numerous premeiotic germ cells expressing pluripotency markers}

The neonatal common marmoset monkey ovary contains numerous oogonia expressing the pluripotency factors OCT4A, SALL4, and LIN28 (Fereydouni et al., 2014). The OCT4A isoform of the OCT4 gene is a premeiotic germline specific marker and one of the most specific and important markers of pluripotency (Scholer et al., 1990; Liedtke et al., 2008; Wang \& Dai, 2010). Many oogonia in the neonatal marmoset ovary are positive for OCT4A indicating a premeiotic stage (Fereydouni et al., 2014, Figure 3 B and C). Those germ cells which already entered meiosis are negative for OCT4A staining. The one-year old and adult ovaries did not show any 
OCT4A positive staining (Fereydouni et al., 2014). Another factor which we used for characterization was SALL4, which is a transcription factor that has an essential role for pluripotency of mouse ES cells (Elling et al., 2006). Hobbs et al. (2012) reported that mouse spermatogonia also depend on SALL4 function. A study conducted in our lab by Eildermann and colleagues (2012) showed that SALL4 protein expression is restricted to premeiotic germ cells in the human and non-human primate testis, including common marmoset monkey testis (Eildermann et al., 2012). In the present study, strong SALL4 signals were seen in oogonia and premeiotic germ cells in the common marmoset neonatal ovary (Fereydouni et al., 2014, Figure 3F and G). The third pluripotency marker which was used was LIN28, is an RNA binding pluripotency-associated protein. Previous studies by our unit demonstrated that LIN28 is expressed in marmoset monkey ES cells and also in premeiotic male human and marmoset monkey germ cells (Aeckerle et al., 2012). Childs et al. (2012) also reported that LIN28 is a specific marker of oogonia and premeiotic germ cells in human fetal ovary. Our study revealed strong LIN28 positive staining for premeiotic germ cells which are organized in clusters in the cortex of neonatal marmoset monkey ovary. The meiotic stages in the cortex were negative for LIN28 staining (Fereydouni et al., 2014, Figure 3J). Some LIN28 and SALL4-positive cells were also detected in the OSE of the neonatal marmoset ovary, but, in contrast, no OCT4A positive cells (Fereydouni et al., 2014, Figure 3G and K). 


\subsection{Presence of pluripotency and germ cell factor mRNAs in the marmoset neonatal ovary}

To corroborate and confirm the expression of the pluripotency markers on the mRNA level, I performed RT-qPCR for VASA, OCT4A, LIN28 and SALL4 on cDNA from the neonatal marmoset ovary. Marmoset ES cells and fibroblasts were used as biological positive and negative control, respectively. I could show that the neonatal marmoset ovary contains significant transcript amounts of these markers (Fereydouni et al., 2014, Figure 2).

\subsection{Co-localization of the germ cell marker VASA with pluripotency markers}

In order to further verify the germ cell identity of the pluripotency factor-positive cells, I performed double staining immunohistochemistry for OCT4A/VASA and LIN28/VASA. VASA is a specific germ cell marker in mammals. With the double staining I demonstrated that OCT4A and LIN28 are indeed expressed in germ cells (Fereydouni et al., 2014, Figure 4).

\subsection{The proliferation marker Ki-67 is strongly expressed by oogonia}

Ki-67 is a specific and reliable marker for proliferative cells (Scholzen\& Gerdes, 2000). Previously, Stoop and colleagues (Stoop et al., 2005) showed that in human ovary, Ki-67 is strongly expressed in oogonia, while oocytes, which are in meiotic phases, were negative for Ki67 staining. I showed by Ki-67 staining that premeiotic germ cells in the common marmoset monkey are still proliferating (Fereydouni et al., 2014, Figure 5). 


\subsection{Co-localization of Ki-67 with the pluripotency markers OCT4A and LIN28}

To test whether the individual cells express both pluripotency and proliferation markers, I performed double staining with the marker combinations OCT4A/Ki-67 and LIN28 /Ki-67. The double staining showed the co-localization for OCT4A/Ki-67 and LIN28/Ki-67 in oogonia (Fereydouni et al, 2014, Figure 6).

\subsection{Establishing two different long-term culture methods from the marmoset neonatal primary cell culture}

In the second part of the study two different culture systems for the long-term culture of ovarian cells were successfully established. The first condition (termed C1) was FBS supplemented DMEM medium. The second condition (C2) was a medium (called ESM) which specifically supports marmoset monkey pluripotent stem cells. Both cell culture systems used Mouse Embryonic Fibroblasts (MEF) as a cell attachment matrix. Under C1 I could pass and expand the cells from 5 different individual primary cultures for more than 5 months; the maximal passage number was 23, after which the cells no longer proliferated. Under C1, initially small ovarian cell colonies (OCCs) formed which were clearly distinguishable from the MEF cells by the morphology of the colonies' boundaries. These OCCs quickly increased in size forming big colonies up to $1000 \mu \mathrm{m}$ in diameter. In higher passages under C1 the number of OCCs increased, but the individual colonies became smaller. Under C2, 3 different individual primary cultures were performed; under this condition I could continue the cultures up to passage 8. The size of OCCs was between 500 to $1000 \mu \mathrm{m}$. OCCs showed distinct borders, the morphology of the cells forming the OCCs under both conditions was epitheloid with a regular cuboidal shape with no visible intracellular spaces (Fereydouni et al, submitted Figure1). 


\subsection{Transcriptome analysis of ovarian cell colonies (OCCs) reveals an immediate loss of the germ cell population in culture}

In order to compare the OCCs from both conditions on the transcriptome level with reference samples (neonatal ovaries, marmoset ES cells and marmoset fibroblasts), transcriptome analyses from early passage-OCCS by deep sequencing were performed. Interestingly, the Principal component analysis (PCA) plot of the transcriptomes showed that the OCCs were closer to ES cells than to the neonatal ovaries and completely separated from the fibroblasts. Many germ cell transcripts present in neonatal ovaries were undetectable in the transcriptomes of the OCCs even in passage 1 revealing an immediate loss of the germ cell population in cell culture (Fereydouni et al, submitted, Figure 2 and Figure S1; S2, Supplementary lists 1 and 2).

In the first part of the study I demonstrated that neonatal marmoset monkey ovaries contain premeiotic germ cells expressing the germ cell marker VASA and germ cell and pluripotency markers (OCT4A, SALL4 and LIN28) (Fereydouni et al., 2014). Also all these markers as well as additional germ cell markers were very poorly represented in the transcriptomes of the early passage OCCs or even undetectable (Fereydouni et al, submitted, Figure 3).

\subsection{RT-qPCR analysis showed the expression of germ cell markers in OCCs}

In order to quantify the expression of some key markers in OCCs also in higher passages, RTqPCR was performed for the pluripotency markers OCT4A and NANOG, the pluripotency and germ cell markers SALL4 and LIN28, and the germ cell marker VASA. The RT-qPCR data confirmed for both cell culture condition that OCT4A and NANOG were not expressed in OCCs. SALL4 and LIN28 as pluripotency and germ cell markers were absent or showed only very low expression in early passages (P1-P3) under both conditions. In contrast to lower passages under 
C1 and all passages under C2, higher passages (except for P9) under C1 exhibited significant expression of LIN28 and SALL4. The expression profile of VASA was similar to the one of SALL4 and LIN28. Importantly, in P5, the relative expression of these three markers was almost in the range of the positive controls (neonatal ovaries and ES cells). For OCCs under C1, I also performed RT-qPCR for early germ line (PRDM1, PRDM14 and DPPA3) and the additional germ cell markers DAZL and NOBOX. The early germ line markers were present in OCCs and ES cells. In contrast, the germ cell markers DAZL and NOBOX were expressed only by OCCs, but not by ES cells. These data show that C1 induces OCCs to express germ cell markers (Fereydouni et al, submitted, Figure 3 and Figure 4).

\subsection{The OCCs under C1 generate oocyte-like cells (OLCs)}

In addition to the germ cell marker expression, the OCCs under C1 could generate large, freefloating spherical cells with a morphology resembling immature oocytes; we called these cells oocyte-like cells (OLCs). Their diameters were in the range of 20-50 $\mu \mathrm{m}$ (Fereydouni et al, submitted, Figure 5A). The OLCs developed only in passages $>4$ up to passage 23 under C1.

\subsection{OLCs express the germ cell markers VASA, DAZL, and NOBOX on the mRNA level}

For initial characterization of the OLCs, they were collected and the expression of important markers was tested by RT-qPCR: namely OCT4A and NANOG, as pluripotency markers, the

pluripotency and germ cell markers SALL4 and LIN28, germ line markers (PRDM14 and $D P P A 3$ ) and the germ cell markers VASA, DAZL and NOBOX. 28 OLCs were randomly allocated to two groups (OLCs1 and OLCs2). OCT4A and NANOG were very low in OLCs 
compared to ES cells. SALL4 and LIN28 were robustly expressed. PRDM14 and DPPA3 were highly expressed in OLCs compared to the positive controls, i.e. ES cells and newborn ovary. Germ cell markers (VASA, DAZL and NOBOX) were expressed only in OLCS and the newborn ovary. These analyses revealed strong expression of these germ cell markers (VASA, DAZL and NOBOX) in OLCs (Fereydouni et al, submitted, Figure 5B).

\subsection{Expression of germ cell marker VASA on the protein level by OLCs}

To detect VASA protein in OLCs I fixed the OCCs containing OLCs in situ and performed immunofluorescence and immunohistochemistry (IHC) analysis. The OLCs showed condensed chromatin by DAPI staining and were labeled by a VASA antibody (Fereydouni et al, submitted, Figure 6D, and E). The IHC staining also demonstrated VASA positive OLCs (Fereydouni et al, submitted, Figure 6F, and G). These experiments revealed isolated VASA-positive OLCs in the long-term cultures from neonatal marmoset monkey ovary (Fereydouni et al, submitted, Figure 6).

\subsection{The relative abundance of the markers is decreasing within one passage}

To obtain initial information on the relative transcript abundance of the different markers during the OCC development within one passage, I isolated RNA from duplicate samples from OCCs (P7) after 2, 4, 6 and 8 days and did RT-qPCR analysis for different markers. OCT4A, NANOG and LIN28 were very low or absent. In contrast VASA and SALL4 were strongly detectable in OCCs at different days. Both markers exhibited a high abundance at day 2. Later time points 
(days 4-8) showed a decrease in transcript relative to GAPDH (Fereydouni et al, submitted, Figure 7).

\subsection{No production of sex steroids by the OCCs}

To check whether the OCCs have the ability to produce female sex steroids like specific ovarian cell types in vivo, medium samples were analyzed from low and high culture passages for estradiol and progesterone. No estradiol and progesterone were detected in medium samples. Moreover, FSHR and LH/CGR transcripts were undetectable in most OCC transcriptomes. Hence, the colonies are not constituted of functional endocrine cells of the ovary (Fereydouni et al, submitted).

\subsection{Neither teratoma nor ovarian tissue formation in a transplantation assay}

In order to test the pluripotency or reconstitution and differentiation capabilities of these cells, a teratoma assay was performed. About $10^{6}$ cells from the 5 th passage were injected subcutaneously in to 4 female adult NOD-SCID mice, each. After 14 weeks, tissues from injection sites were analyzed. No teratoma or ovary-like structures were found (Fereydouni et al, submitted). 


\section{Brief discussion}

In the course of my PhD project we performed to my knowledge the first histological analysis of the neonatal marmoset monkey ovary. Also, we showed that there are numerous oogonia present in the postnatal marmoset ovary. This is in sharp contrast to the humans, macaques and also to rodents in which almost all oogonia enter meiosis before birth. The neonatal marmoset ovary exhibits also a histologically undifferentiated zone underneath the ovarian surface epithelium. We termed this zone indifferent cortical zone (ICZ), which has no histological counterpart in the neonatal human ovary (Van Wagnen \& Simpson 1973, Sforza et al., 1993).

In contrast to the adult and the one-year-old marmoset ovary, the neonatal marmoset monkey ovary contains numerous premeiotic germ cells which are positive for pluripotency factors (OCT4A, LIN28, and SALL4) and the proliferation marker Ki-67. These expression data are clearly in contrast to the human neonatal ovary, where most oogonia enter meiosis during fetal development (Stoop et al., 2005, Byskov et al., 2011).

Several reports supported the presence of germline stem cells in the postnatal mouse ovary (Johnson et al., 2005; Pacchiarotti et al., 2010 and Zou et al., 2009), still the presence of germline stem cells in the postnatal ovary is very controversial. In the present study the ovarian cell colonies (OCCs) were derived from primary ovarian cells and cultured and expanded for the long-term under two conditions, $\mathrm{C} 1$ and $\mathrm{C} 2$. The morphology of the OCCs resembled the colonies from mouse ovarian cell cultures which have been observed previously by (Pacchiarotti et al., 2010) and (Gong et al., 2010). In the present study, OCCs strongly expressed germ cell markers (VASA, SALL4) but not pluripotency markers (OCT4A and NANOG). This was in 
contrast to the publication by Gong et al. (2010) who reported strong expression of the pluripotency markers OCT4 and NANOG in mouse OCCs.

However, in our study the cultured cells are not pluripotent stem cells or germ (line stem) cells, as has been suggested in previous reports (Gong et al. 2010, Pacchiarotti et al. 2010, Stimpfel et al. 2013).

From passage 4 (under condition 1) onwards, oocyte-like cells (OLCs) were observed. They had a diameter of about $50 \mu \mathrm{m}$. The OLCs developed in cell culture for more than 4 months and could still be observed at high passages (> 20). The detection of the germ cell markers VASA, DAZL, SALL4 and NOBOX by RT-qPCR and of VASA by immunofluorescence staining confirmed that OLCs are germ line cells. Previously White et al. (2012), reported that isolated mitotically active cells from the human adult ovarian cortex had the potential to form oocyte-like cells in vitro.

In the present study, pluripotent stem and germ cell markers were generally absent in low OCC passages, and there was no OLC development from low OCC passages. These data suggest that there are stem/premeiotic germ cells progenitors present in early OCC passages that lack classical premeiotic germ cell characteristics, but have the potential to develop OLCs in longterm cultures. This observation as well as the long-term development of OLCs in the cultures themselves is in agreement with the idea of the presence female germline stem cells in the cultures under condition 1 . However, so far we were not able to identify these putative cells in our cell culture. One candidate tissue for the presence of ovarian stem cells could be the ovarian surface epithelium, which was previously reported by (Bukovsky et al., 2009). 


\section{Conclusion}

In conclusion, we tested two different long-term cell culture conditions. However, only the FBSbased condition supported OLC development in vitro while under ES cell culture conditions, no OLCs developed. Together, the data substantiate the view that there are stem and / or progenitor cells present in early OCC passages that lack germ cell characteristics, but have the potential to develop OLCs in higher passages. So far we were not able to identify the origins of these cells. Moreover, it is still unclear whether OLCs have an in vivo function or not. To our knowledge, we have for the first time successfully established a non-human primate cell culture system that allows the long-term culture and development of OLCs from a non-human primate species. 


\section{Perspectives}

Based on our studies, future experiments will aim at identifying and characterizing the stem / progenitor cell population which has the potential to give rise to oocyte-like cells from OCCs. However, the functionality of the cells needs to be studied. This can be done either by refined cultures systems or by transplantation approaches using genetically labeled cells. The latter approach would enable tracing of the cells after transplantation into recipient marmoset ovaries possibly providing novel insights into primate ovarian germ cell biology and function. 


\section{References}

Anderson, LD, and AN Hirshfield 1992An overview of follicular development in the ovary: from embryo to the fertilized ovum in vitro. MD MED. J 41 614-620.

Aeckerle, N, K Eildermann, C Drummer, J Ehmcke, S Schweyer, A Lerchl, M Bergmann, S Kliesch, J Gromoll, S Schlatt, and R Behr 2012 The pluripotency factor LIN28 in monkey and human testes: a marker for spermatogonial stem cells? Mol Hum Reprod 18 477-488.

Albert, S, J Ehmcke, J Wistuba, K Eildermann, R Behr, S Schlatt, and J Gromoll 2010 Germ cell dynamics in the testis of the postnatal common marmoset monkey (Callithrix jacchus). Reproduction 140 733-742.

Beindorff, N, and A Einspanier 2010 Luteotrophic effects of relaxin, chorionic gonadotrophin and FSH in common marmoset monkeys (Callithrix jacchus). Reproduction 139 923-930.

Bendsen, E, AG Byskov, CY Andersen, and LG Westergaard 2006 Number of germ cells and somatic cells in human fetal ovaries during the first weeks after sex differentiation. Hum Reprod 21 30-35.

Borum, K 1961Oogenesis in the mouse. A study of meiotic prophase. EXP. CELL RES 24 495507.

Bukovsky, A, JA Keenan, MR Caudle, J Wimalasena,NB Upadhyaya, and SE Van Meter 1995 Immunohistochemical studies of the adult human ovary: possible contribution of immune and epithelial factors to folliculogenesis. AM J REPROD IMMUNOL 33 323-340. 
Byskov, AG, MJ Faddy, JG Lemmen, and CY Andersen 2005 Eggs forever? Differentiation 73 438-446.

Byskov, AG, PE Hoyer, C Yding Andersen, SG Kristensen, A Jespersen, and K Mollgard 2011 No evidence for the presence of oogonia in the human ovary after their final clearance during the first two years of life. Hum Reprod 26 2129-2139.

Chandolia, RK, CM Luetjens, J Wistuba, CH Yeung, E Nieschlag, and M Simoni 2006 Changes in endocrine profile and reproductive organs during puberty in the male marmoset monkey (Callithrix jacchus). Reproduction 132 355-363.

Childs, AJ, HL Kinnell, J He, and RA Anderson 2012 LIN28 is selectively expressed by primordial and pre-meiotic germ cells in the human fetal ovary. Stem Cells Dev 21 2343-2349.

Eildermann, K, N Aeckerle, K Debowski, M Godmann, H Christiansen, M Heistermann, S Schweyer, M Bergmann, S Kliesch, J Gromoll, J Ehmcke, S Schlatt, and R Behr 2012 Developmental expression of the pluripotency factor sal-like protein 4 in the monkey, human and mouse testis: restriction to premeiotic germ cells. Cells Tissues Organs 196 206-220.

Elling, U, C Klasen, T Eisenberger, K Anlag, and M Treier 2006 Murine inner cell massderived lineages depend on Sall4 function. Proc Natl Acad Sci U S A 103 16319-16324.

Fereydouni, B, C Drummer, N Aeckerle, S Schlatt; and B Behr 2014The neonatal marmoset monkey ovary is very primitive compared to the human exhibiting many oogonia. Reproduction REP-14-0068.

Forabosco, A, C Sforza, A De Pol, L Vizzotto, L Marzona, and VF Ferrario 1991 Morphometric study of the human neonatal ovary. Anat Rec 231 201-208. 
Gerard; P 1920 Contribution a l'etude de l'ovaire des Mammiferes. L'ovaire de Galago mossambicus (Young). ARCH BIOL. 30 357-391.

Gong; SP, ST Lee, EJ Lee, DY Kim, G Lee, SG Chi, BK Ryu, CH Lee, KE Yum, HJ Lee, JY Han, JL Tilly; and JM Lim 2010 Embryonic stem cell-like cells established by culture of adult ovarian cells in mice. Fertil Steril 93 2594-2601, 2601 e2591-2599.

Gougeon, A 1996 Regulation of ovarian follicular development in primates: facts andhypotheses. ENDOCR. REV 17 121-155.

Hanazawa, K, T Mueller, T Becker, M Heistermann, R Behr, and E Sasaki 2012 Minimally invasive transabdominal collection of preimplantation embryos from the common marmoset monkey (Callithrix jacchus). Theriogenology 78 811-816.

Hartshorne, GM, S Lyrakou, H Hamoda, E Oloto E, and F Ghafari 2009 Oogenesis and cell death in human prenatal ovaries: what are the criteria for oocyte selection? Mol Hum Reprod 15 805-819.

Hearn, JP 1983 The common marmoset (Callithrix jacchus). In JP Hearn (ed.), Reproduction in new world primates: new models in medical science, pp. 181-215. Lancester: MTP Press.

Hobbs, RM, S Fagoonee, A Papa, K Webster, F Altruda, R Nishinakamura, L Chai, and PP Pandolfi 2012 Functional antagonism between Sall4 and Plzf defines germline progenitors. Cell Stem Cell 10 284-298.

Johnson, J, J Bagley, M Skaznik-Wikiel, HJ Lee, GB Adams, Y Niikura, KS Tschudy, JC Tilly, ML Cortes, R Forkert, T Spitzer, J Iacomini, DT Scadden, and JL Tilly 2005 Oocyte 
generation in adult mammalian ovaries by putative germ cells in bone marrow and peripheral blood. Cell 122 303-315.

Kerr, JB, M Myers, KL Britt,T Mladenovska, JK Findlay 2006 Quantification of healthy follicles in the neonatal and adult mouse ovary: evidence for maintenance of primordial follicle supply. REPRODUCTION 132 95-109.

Li, LH, JM Donald, and MS Golub 2005 Review on testicular development, structure, function, and regulation in common marmoset. Birth Defects Res B Dev Reprod Toxicol 74 450469.

Liedtke, S, M Stephan, and G Kogler 2008 Oct4 expression revisited: potential pitfalls for data misinterpretation in stem cell research. Biol Chem 389 845-850.

Lin, ZY, M Imamura, C Sano, R Nakajima, T Suzuki, R Yamadera, Y Takehara, HJ Okano, E Sasaki, and H Okano 2012 Molecular signatures to define spermatogenic cells in common marmoset (Callithrix jacchus). Reproduction 143 597-609.

Liu, Y, C Wu, QLyu, D Yang D, DF Albertini, DL Keefe, and L Liu 2007 Germline stem cells and neo-oogenesis in the adult human ovary. Dev Biol 306 112-120.

Luetjens, CM, JB Stukenborg, E Nieschlag, M Simoni, and J Wistuba 2008 Complete spermatogenesis in orthotopic but not in ectopic transplants of autologously grafted marmoset testicular tissue. Endocrinology 149 1736-1747.

Maheshwari, A, and PA Fowler 2008 Primordial follicular assembly in humans--revisited. Zygote 16 285-296. 
Mansfield, K 2003 Marmoset models commonly used in biomedical research. Comp Med 53 383-392.

McKinnell, C, RT Mitchell, K Morris, RA Anderson, CJ Kelnar, WH Wallace, and RM Sharpe 2013 Perinatal germ cell development and differentiation in the male marmoset (Callithrix jacchus): similarities with the human and differences from the rat. Hum Reprod 28 886-896.

McKinnell, C, RT Mitchell, M Walker, K Morris, CJ Kelnar, WH Wallace, and RM Sharpe 2009 Effect of fetal or neonatal exposure to monobutyl phthalate (MBP) on testicular development and function in the marmoset. Hum Reprod 24 2244-2254.

McLaren ,A1984Meiosis and differentiation of mouse germ cells. SYMP. SOC. EXP. BIOL 38 $7-23$.

Mitchell, RT, G Cowan, KD Morris, RA Anderson, HM Fraser, KJ McKenzie, WH Wallace, CJ Kelnar, PT Saunders, and RM Sharpe 2008 Germ cell differentiation in the marmoset (Callithrix jacchus) during fetal and neonatal life closely parallels that in the human. Hum Reprod 23 2755-2765.

Pacchiarotti , J, C Maki, T Ramos, J Marh, K Howerton, J Wong, J Pham, S Anorve, YC Chow, and F Izadyar 2010 Differentiation potential of germ line stem cells derived from the postnatal mouse ovary. Differentiation 79 159-170.

Parte, S, D Bhartiya, DD Manjramkar, A Chauhan, and A Joshi 2013 Stimulation of ovarian stem cells by follicle stimulating hormone and basic fibroblast growth factor during cortical tissue culture. J Ovarian Res 620. 
Parte, S, D Bhartiya, J Telang, V Daithankar, V Salvi, K Zaveri K , and I Hinduja 2011 Detection, characterization, and spontaneous differentiation in vitro of very small embryonic-like putative stem cells in adult mammalian ovary. Stem Cells Dev 20 1451-1464.

Peters, H 1970 Migration of gonocytes into the mammalian gonad and their differentiation.PHIL. TRANS. R. SOC. LOND. B 259 91-101.

Sasaki, E, K Hanazawa, R Kurita, A Akatsuka, T Yoshizaki, H Ishii, Y Tanioka, Y Ohnishi, H Suemizu, A Sugawara, N Tamaoki, K Izawa, Y Nakazaki, H Hamada, H Suemori, S Asano, N Nakatsuji, H Okano, and K Tani 2005 Establishment of novel embryonic stem cell lines derived from the common marmoset (Callithrix jacchus). Stem Cells 23 1304-1313.

Sasaki, E, H Suemizu, A Shimada, K Hanazawa, R Oiwa, M Kamioka, I Tomioka, Y Sotomaru, R Hirakawa, T Eto, S Shiozawa, T Maeda, M Ito, R Ito, C Kito, C Yagihashi, K Kawai, H Miyoshi, Y Tanioka, N Tamaoki, S Habu, H Okano, and T Nomura 2009 Generation of transgenic non-human primates with germline transmission. Nature 459 523-527.

Scholer, HR, S Ruppert, N Suzuki, K Chowdhury, and P Gruss 1990 New type of POU domain in germ line-specific protein Oct-4. Nature 344 435-439.

Stimpfel, M, T Skutella, B Cvjeticanin, M Meznaric M, P Dovc, S Novakovic, P Cerkovnik, E Vrtacnik-Bokal, and I Virant-Klun 2013 Isolation, characterization and differentiation of cells expressing pluripotent/multipotent markers from adult human ovaries. Cell Tissue Res 354 593-607. 
Stoop, H, F Honecker, M Cools, R de Krijger, C Bokemeyer, and LH Looijenga 2005 Differentiation and development of human female germ cells during prenatal gonadogenesis: an immunohistochemical study. Hum Reprod 20 1466-1476.

Telfer, EE, RG Gosden RG, AG Byskov AG et al 2005 On regenerating the ovary and generating controversy. CELL 122 821-822.

Tomioka, I, T Takahashi, A Shimada, K Yoshioka, and E Sasaki 2012 Birth of common marmoset (Callithrix jacchus) offspring derived from in vitro-matured oocytes in chemically defined medium. Theriogenology 78 1487-1493.

van Wagenen, G, and ME Simpson 1973 Postnatal development of the ovary in Homo sapiens and Macaca mulatta and Induction of Ovulation in the Macaque. New Haven and London: Yale University Press.

von Schonfeldt, V, R Chandolia, L Kiesel, E Nieschlag, S Schlatt, and B Sonntag 2011 Advanced follicle development in xenografted prepubertal ovarian tissue: the common marmoset as a nonhuman primate model for ovarian tissue transplantation. Fertil Steril 95 1428-1434.

Zuckerman, S 1951 The number of oocytes in the mature ovary. Recent Prog Horm Res 6 63108.

Ioannou, JM 1967 Oogenesis in adult prosimians. J Embryol Exp Morphol 17 139-145.

Yuan, J, D Zhang, L Wang, M Liu, J Mao, Y Yin, X Ye, N Liu, J Han,Y Gao, T Cheng, DL Keefe , and L Liu 2013 No evidence for neo-oogenesis may link to ovarian senescence in adult monkey. Stem Cells 31 2538-2550. 
Sforza, C, VF Ferrario, A De Pol, L Marzona, M Forni, and A Forabosco 1993

Morphometric study of the human ovary during compartmentalization. Anat Rec 236 626-634.

Wang, X, and J Dai 2010 Concise review: isoforms of OCT4 contribute to the confusing diversity in stem cell biology. Stem Cells 28 885-893.

White, YA, DC Woods, Y Takai, O Ishihara, H Seki, and JL Tilly 2012 Oocyte formation by mitotically active germ cells purified from ovaries of reproductive-age women. Nat Med 18 413421

Zou, K, Z Yuan, Z Yang, H Luo, K Sun, L Zhou, J Xiang, L Shi, QYu, Y Zhang, R Hou R, and J Wu 2009 Production of offspring from a germline stem cell line derived from neonatal ovaries. Nat Cell Biol 11 631-636.

\section{Book}

Junqueira, L. \& Carneiro, j. (11th). (2005). Basic Histology: Text \& Atlas. McGraw-Hill Companies. 


\section{Curriculum Vitae}

\section{Bentolhoda Fereydouni}

Stem Cell Biology Unit German Primate Center Leibniz Institute for Primate Research Kellnerweg 4

37077 Goettingen Germany

Phone: +49-551-3851-325/326

Email: bfereydouni@dpz.eu, b.fereydouni@gmail.com

\section{Personal}

Nationality: Iranian Place of birth: Dubai

\section{Languages}

Persian (Native)

English (Excellent)

German (Good) Intensive German courses at the Goethe-Institute Goettingen

Arabic (Intermediate)

French (Basic knowledge)

\section{Current Position}

Ph.D. student in Faculty of Biology, Georg-August-University, Goettingen

\section{Education}

- PhD in Biology at George-August University of Goettingen, Goettingen, Germany, 2010-2014

- M.Sc. in Cell developmental biology, Shiraz University, Shiraz, Iran. Total GPA: 18.73,20 (Thesis GPA: 19.75,20). 2007- 2009.

- B.Sc.in Biology, Shiraz University, Shiraz, Iran, First rank student with GPA: 17.79,20. 2003- 2007.

\section{Awards}

- DAAD (German Academic Exchange Service) scholarship 2010 to pursue PhD studies in Germany.

- Singapore International Graduate Award (SINGA) 2010.

- Received an award annually as the permanent gifted student, office of gifted Students, Shiraz University, Shiraz, Iran, 2003-2009. 


\section{Honors}

- Best Honor in the Qualification Exam for the M.S. Program in Biology Field, 2007, Shiraz, Iran.

- Best Honor Graduated Student among all of Graduated Students in Bachelor Degree level in Shiraz University, July 2007, Shiraz, Iran.

- 1st rank Student in Shiraz University in biology 2004, 2005, 2006 and 2007.

- Best Honor in the First Student's Biology Olympiad in South of Iran 2007

- $12^{\text {th }}$ rank at the final stage in $12^{\text {th }}$ National Scientific Olympiad on Biology, 2007.

- $2^{\text {nd }}$ rank in the Student's Biology Olympiad in South of Iran 2006.

- $19^{\text {th }}$ rank in the final stage in the $11^{\text {th }}$ National Scientific Olympiad on Biology, 2006.

- Shiraz University distinguished student 2006.

- Accepted with top 1\% ranking in National Entrance Examination, 2003.

\section{Research Experience}

- 2010-2014: PhD project: "In situ and in vitro analysis of germ and stem cell marker-positive cells in the postnatal ovary of the common marmoset monkey (Callithrix jacchus)" Stem Cell Biology Unit, German Primate Center, Leibniz Institute for Primate Research, Goettingen, Germany.

- 2007- 2009: M.Sc. Thesis: "Using Mesenchymal stem cells for regenerating seminiferous tubules in sterile male rats" with collaboration Stem cell laboratory, Anatomy Department, Shiraz University of Medical Sciences

- 2006- 2007: the project "effect of cadmium pollution in female rat's reproductive system" with financial support from Shiraz University office of gifted students.

\section{Teaching Experience}

- Teaching immunohistochemistry methods for the lab rotations of the DNB (Developmental, Neural, and Behavioral Biology) Master students autumn semester 2011, 2012 and 2013.

- Supervising master student, lab rotation project for 2 months, November and December 2013.

- 2007-2009: Teacher assistant, Grader, and Tutor in Embryology, Histology Lab, and Zoology in Biology department, Shiraz University. 


\section{Publications}

1- Bentolhoda Fereydouni, Gabriela Salinas-Riester, Michael Heistermann, Ralf Dressel, Lucia Lewerich, Charis Drummer, and Rüdiger Behr. Long-term oocyte-like cell development in cultures derived from neonatal marmoset monkey ovary Submitted to STEM CELLS.

2- Bentolhoda Fereydouni, Charis Drummer, Nelia Aeckerle, Stefan Schlatt, and Rüdiger Behr. The neonatal marmoset monkey ovary is very primitive exhibiting many oogonia, Reproduction. 2014 May 19. pii: REP-14-0068. [Epub ahead of print] http://www.ncbi.nlm.nih.gov/pubmed/24840529

3. Malihezaman Monsefi., Bentolhoda Fereydouni, Leili Rohani, Tahereh Talaei. Mesenchymal stem cells repair germinal cells of seminiferous tubules of sterile rats. Iranian Journal of Reproductive Medicine Vol. 11. No.7. pp: 537-544, July 2013.

http://www.ncbi.nlm.nih.gov/pubmed/24639788

4. Maliheazaman Monsefi and Bentolhoda Fereydouni. The Effects of Cadmium Pollution on Female Rat Reproductive System, Journal of Infertility and Reproductive Biology, 2013, Volume 1, Issue 1, Pages 1-6. http://www.jirb.dormaj.com/Volume1,\%20lssue\%201\%20\%282013\%29.htm

5. Fereydouni, Shapour; Fereydouni, Bentolhoda; Soleimani, Hamideh. Attitude of Male and Female Subjects towards Oocyte Donation in Shiraz, Journal of Reproduction and infertility, volume 10, issue 1, April 2009. http://www.jri.ir/en/showarticle.aspx?id=358

\section{Articles in Preparation}

- Study of germ cells markers in the ovary of the common marmoset monkey (Callithrix jacchus).

\section{Selected conferences}

1. B. Fereydouni and R. Behr, Bone morphogenetic protein 15 (BMP15) and growth differentiation factor 9 (GDF9) expression is developmentally regulated in ovary of the common marmoset monkey (Callithrix jacchus), The International Student Congress of (bio) Medical Sciences (ISCOMS) 2013, 5-8th June 2013, Groningen, Netherland.

2. B. Fereydouni and R. Behr, Study of pluripotency markers in the ovary of the common marmoset monkey (Callithrix jacchus), The $4^{\text {th }}$ EMBO Meeting 2012, Nice, France 22-25 September 2012.

3. B. Fereydouni, M. Monsefi, T. Talaee, Using mesenchymal stem cells for regenerating seminiferous tubules in sterile male rats, International Anatomical Sciences and Cell Biology Conference (IASCBC). 26- 29 May 2010 National University of Singapore, Singapore.

4. B. Fereydouni, Sh. Fereydouni, H. Solimani, "Public opinion regarding oocyte donation in Iran. International Twin Congress, 28-30 August, 2008, Royan Institute, Tehran, Iran 
5. B. Fereydouni, M. Monsefi, the Effect of Cadmium Pollution in Female Rat Reproductive System, International Anatomy Congress,16-19 May 2008, Tehran, Iran.

6. B. Fereydouni, Using Stem Cells for Curing Some Disease, Principle of Stem cells Conference, with cooperation of Royan Research Institute, 8-9 May 2008, Shiraz, Iran.

7. B. Fereydouni, M. Monsefi. The Effect of Cadmium Pollution in Maharloo Lake (Shiraz, Iran) on Rat Female Reproductive System, the British Toxicology Society Congress, 6-9 April 2008, University of Guilford, Surrey, United Kingdom.

\section{References}

\section{1- Prof. Dr. Rüdiger Behr (Head of the Group)}

Stem Cells Biology Unit, German Primate Center (DPZ), Leibniz Institute for Primate Research Kellnerweg 4, 37077 Goettingen,Germany

Tel.: +495513851 132

Fax: +495513851302

E-mail: rbehr@dpz.eu

http://www.dpz.eu

\section{2- Prof. Dr. Lutz Walter (Head of the Group)}

Primate Genetics Laboratory, German Primate Center (DPZ), Leibniz Institute for Primate Research , Kellnerweg 4,37077 Goettingen, Germany

Tel.: +495513851 161

Fax: +495513851372

E- mail: walter@dpz.eu

$\underline{\text { http://www.dpz.eu }}$ 